In cooperation with the Pennsylvania Department of Transportation Engineering District 6-0

Physical and Vegetative Characteristics of a Newly Constructed Wetland and Modified Stream Reach, Tredyffrin Township, Chester County, Pennsylvania, 2000-2006

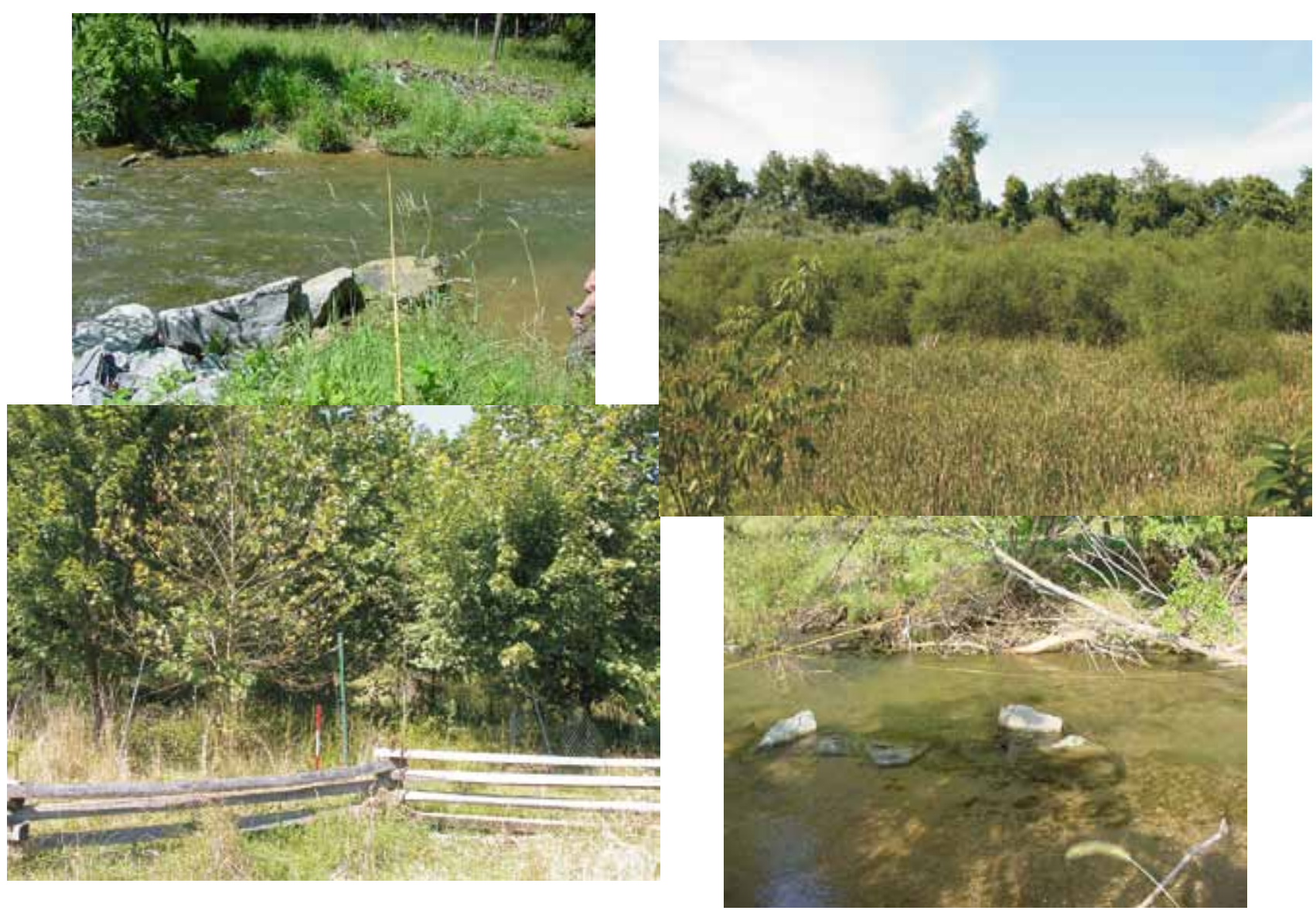

Scientific Investigations Report 2009-5020 


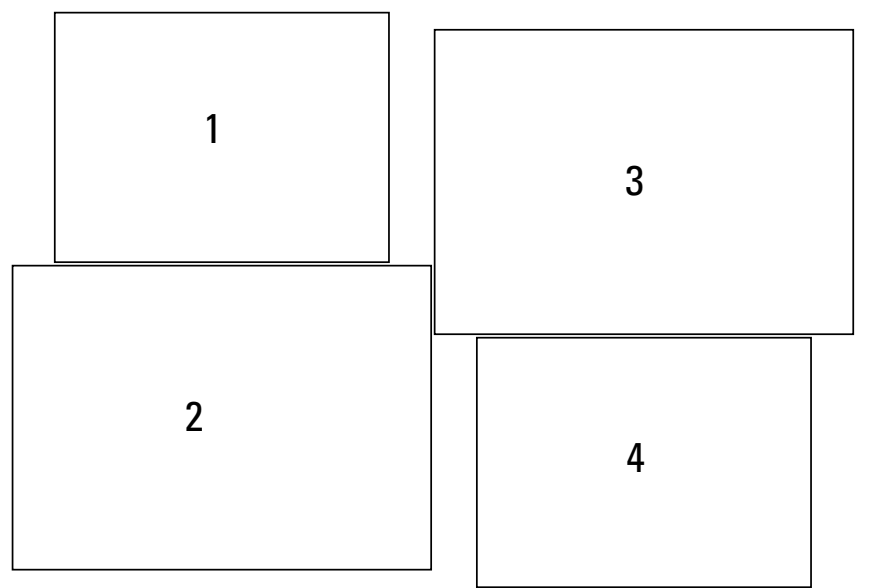

\section{Cover.}

1. View of the upstream rock deflector, June 2001.

2. Riparian-buffer plantings in group 15, September 2005.

3. View of the constructed wetland from photo station 3, September 2006.

4. View of downstream rock deflector, September 2006. 


\section{Physical and Vegetative Characteristics of a Newly Constructed Wetland and Modified Stream Reach, Tredyffrin Township, Chester County, Pennsylvania, 2000-2006}

By Jeffrey J. Chaplin, Kirk E. White, and Leif E. Olson

In cooperation with the Pennsylvania Department of Transportation Engineering District 6-0

Scientific Investigations Report 2009-5020 


\section{U.S. Department of the Interior \\ KEN SALAZAR, Secretary}

\section{U.S. Geological Survey \\ Suzette M. Kimball, Acting Director}

\section{U.S. Geological Survey, Reston, Virginia: 2009}

For product and ordering information:

World Wide Web: http://www.usgs.gov/pubprod

Telephone: 1-888-ASK-USGS

For more information on the USGS—-the Federal source for science about the Earth, its natural and living resources, natural hazards, and the environment:

World Wide Web: http://www.usgs.gov

Telephone: 1-888-ASK-USGS

Any use of trade, product, or firm names is for descriptive purposes only and does not imply endorsement by the U.S. Government.

Although this report is in the public domain, permission must be secured from the individual copyright owners to reproduce any copyrighted materials contained within this report.

Suggested citation:

Chaplin, J.J., White, K.E., and Olson, L.E., 2009, Physical and vegetative characteristics of a newly constructed wetland and modified stream reach, Tredyffrin Township, Chester County, Pennsylvania, 2000-2006: U.S. Geological Survey Scientific Investigations Report 2009-5020, 64 p. 


\section{Contents}

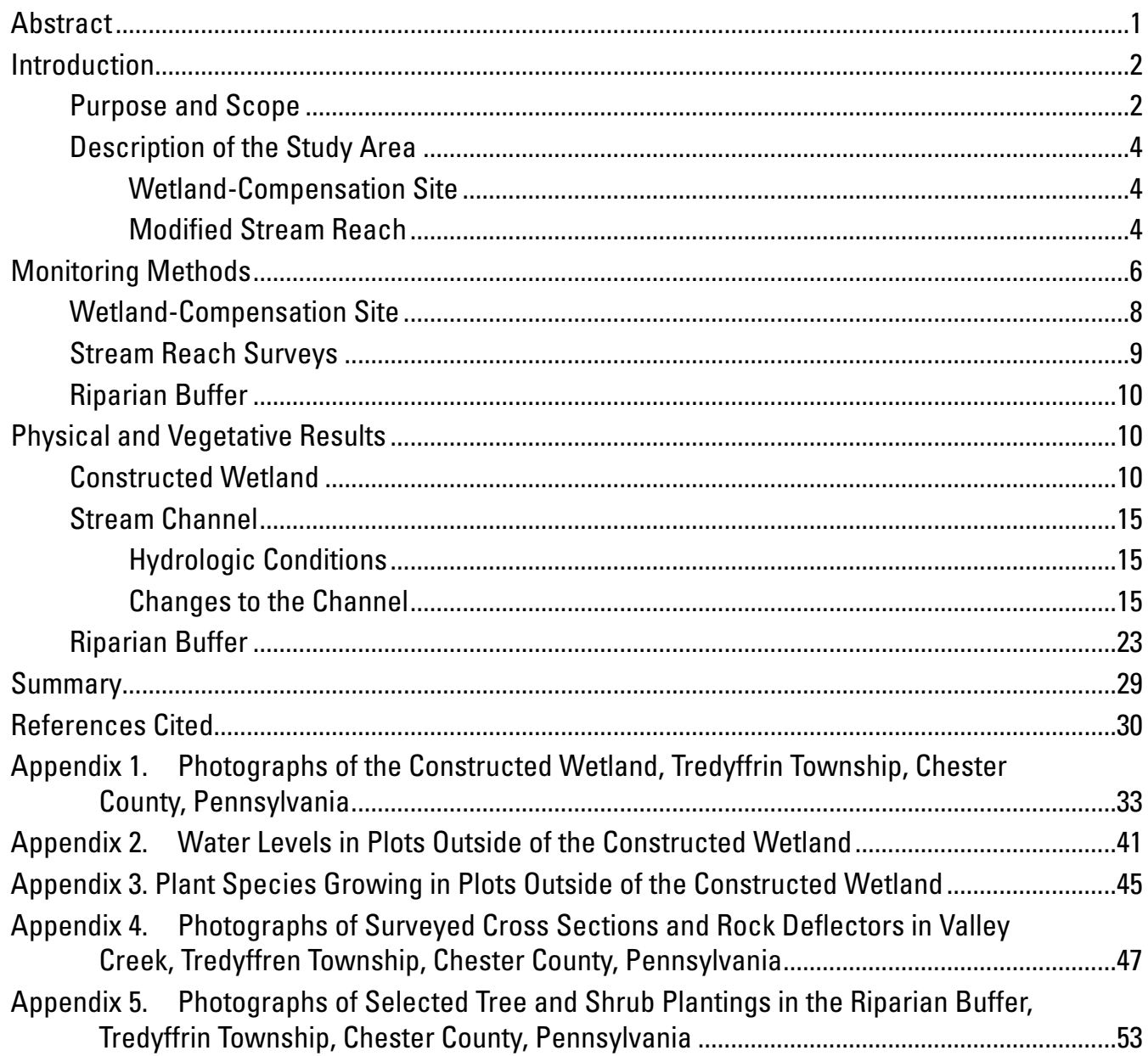




\section{Figures}

1. Map showing location of the wetland-compensation site and modified stream reach, Tredyffrin Township, Chester County, Pennsylvania

2. Map showing wetland-compensation site, Tredyffrin Township, Chester County, Pennsylvania

3. Photographs showing views of a berm for U.S. Highway 202 and a terrace that bound the constructed wetland to the south, west, and north

4. Map showing locations of the stabilization structures and riparian plantings within the modified stream reach, Tredyffrin Township, Chester County, Pennsylvania.

5. Graphs showing water levels at sampling plots within the constructed wetland, Tredyffrin Township, Chester County, Pennsylvania, 2000-2006

6-14. Graphs showing:

6. Longitudinal profile of the upstream reach of the modified stream reach, Tredyffrin Township, Chester County, Pennsylvania

7. Longitudinal profile of the downstream reach of the modified stream reach, Tredyffrin Township, Chester County, Pennsylvania...

8. Surveys of the upstream cross section of the modified stream reach, Tredyffrin Township, Chester County, Pennsylvania...

9. Surveys of the downstream cross section of the modified stream reach, Tredyffrin Township, Chester County, Pennsylvania

10. Comparison of particle-size distributions in the upstream cross section, 2001-2006.

11. Comparison of particle-size distributions in the downstream cross section, 2001-2006

12. Number of planted trees and shrubs growing in the riparian buffer, Tredyffrin Township, Chester County, Pennsylvania, 2001-2006.

13. Percentage of planted species of trees and shrubs in the riparian buffer that were stressed, Tredyffrin Township, Chester County, Pa., 2001-2006 .........26

14. Number of Acer negundo (box elder) and Gymnocladus dioicus (Kentucky coffee tree) plants growing in the riparian buffer, Tredyffrin Township, Chester County, Pennsylvania, 2001-2006 


\section{Tables}

1. Summary of dates for data collection at the constructed wetland and modified stream reach, Tredyffrin Township, Chester County, Pennsylvania .8

2. Areal cover of vegetation in the constructed wetland, Tredyffrin Township, Chester County, Pennsylvania, 2000-2006

3. Observations of hydric-soil indicators in the constructed wetland, Tredyffrin Township, Chester County, Pennsylvania, 2000-2006

4. Cumulative precipitation measured at Valley Forge National Historical Park for water years 2000-2006, Montgomery County, Pennsylvania..

5. Longitudinal profile characteristics of the upstream reach of the modified stream channel, Tredyffrin Township, Chester County, Pennsylvania

6. Longitudinal profile characteristics of the downstream reach of the modified stream channel, Tredyffrin Township, Chester County, Pennsylvania

7. Cross-section dimensions and bed-particle-size distribution in the upstream reach Tredyffrin Township, Chester County, Pennsylvania .....

8. Cross-section dimensions and bed-particle-size distribution in the downstream reach Tredyffrin Township, Chester County, Pennsylvania...........................................23

9. Woody trees and shrubs growing in the riparian buffer, fall 2006 .

\section{Conversion Factors and Abbreviations}

\begin{tabular}{|c|c|c|}
\hline Multiply & By & To obtain \\
\hline \multicolumn{3}{|c|}{ Length } \\
\hline inch (in.) & 2.54 & centimeter $(\mathrm{cm})$ \\
\hline inch (in.) & 25.4 & millimeter $(\mathrm{mm})$ \\
\hline foot $(\mathrm{ft})$ & 0.3048 & meter $(\mathrm{m})$ \\
\hline mile (mi) & 1.609 & kilometer (km) \\
\hline \multicolumn{3}{|c|}{ Area } \\
\hline acre & 4,047 & square meter $\left(\mathrm{m}^{2}\right)$ \\
\hline acre & 0.004047 & square kilometer $\left(\mathrm{km}^{2}\right)$ \\
\hline square foot $\left(\mathrm{ft}^{2}\right)$ & 0.09290 & square meter $\left(\mathrm{m}^{2}\right)$ \\
\hline square mile $\left(\mathrm{mi}^{2}\right)$ & 2.590 & square kilometer $\left(\mathrm{km}^{2}\right)$ \\
\hline \multicolumn{3}{|c|}{ Flow rate } \\
\hline cubic foot per second $\left(\mathrm{ft}^{3} / \mathrm{s}\right)$ & 0.02832 & cubic meter per second $\left(\mathrm{m}^{3} / \mathrm{s}\right)$ \\
\hline
\end{tabular}





\title{
Physical and Vegetative Characteristics of a Newly Constructed Wetland and Modified Stream Reach, Tredyffrin Township, Chester County, Pennsylvania, 2000-2006
}

\author{
By Jeffrey J. Chaplin, Kirk E. White, and Leif E. Olson
}

\section{Abstract}

To compensate for authorized disturbance of naturally occurring wetlands and streams during roadway improvements to U.S. Highway 202 in Chester and Montgomery Counties, Pa., the Pennsylvania Department of Transportation (PennDOT) constructed 0.42 acre of emergent wetland and 0.94 acre of scrub-shrub/forested wetland and modified sections of a 1,600-foot reach of Valley Creek with woody riparian plantings and streambank-stabilization structures (including rock deflectors). In accordance with project permits and additional guidance issued by the U.S. Army Corps of Engineers, the U.S. Geological Survey (USGS), in cooperation with PennDOT, collected data from 2000 through 2006 to quantify changes in 1) the vegetation, soils, and extent of emergent and scrub-shrub/forested parts of the constructed wetland, 2) the profile, dimension, and substrate in the vicinity of rock deflectors placed at two locations within the modified stream reach, and 3 ) the woody vegetation within the planted riparian buffer. The data for this investigation were collected using an approach adapted from previous investigations so that technology and findings may be more easily transferred among projects with similar objectives.

Areal cover by planted and non-planted vegetation growing within the emergent and scrub-shrub/forested parts of the constructed wetland exceeded 85 percent at the end of each growing season, a criterion in special condition $25 \mathrm{c}$ in the U.S. Army Corps of Engineers project permit. Areal cover of vegetation in emergent and scrub-shrub/forested parts of the constructed wetland exceeded 100 percent in all but one growing season. Frequent and long-lasting soil saturation favored obligate-wetland species like Typha latifolia (broadleaf cattail) and Scirpus validus (great bulrush), both of which maintained dominance in the emergent wetland throughout the study (percent cover was 20 and 78 percent, respectively, in 2006). Echinocloa crusgalli (barnyard grass), an annual invasive from Eurasia, initially established in the newly disturbed soils of the scrub-shrub/forested wetland (areal cover was 56 per- cent in 2000), but by 2002, E. crusgalli was not growing in any sample plots and other species including Agrostis stolonifera (creeping bent grass), Festuca rubra (red fescue), Cornus spp. (dogwood species), and Salix nigra (black willow) were becoming more common. Sal. nigra contributed 30-percent cover in the scrub-shrub/forested wetland part by fall 2003. Rapid colonization of this species in subsequent years increased annual cover through 2006, when 15- to 25-foot tall Sal. nigra trees dominated the tree/shrub stratum (48 percent of the areal cover in 2006). The understory of the scrub-shrub/ forested wetland was mostly shaded because of the canopy of Sal. nigra trees. Herbaceous species growing under and near the margins of the canopy included Ag. stolonifera and Ty. latifolia (29- and 23-percent areal cover, respectively).

Flows in Valley Creek are responsible for transporting sediment and shaping the channel. Annual mean streamflow during the period the modified stream reach was monitored ranged from 15.2 cubic feet per second $\left(\mathrm{ft}^{3} / \mathrm{s}\right)$ in the 2002 water year to $53.0 \mathrm{ft}^{3} / \mathrm{s}$ in the 2004 water year. This is a range of about 55 percent lower to 58 percent higher than the annual mean streamflow for the period of record. Despite the variability in streamflow, longitudinal profiles surveyed near rock deflectors in two short (100-foot) reaches within the modified stream reach maintained a constant slope throughout the monitoring period, most likely because of the presence of bedrock control. Cross-section geometry in the upstream reach was virtually unchanged during the monitoring period but 10 feet of bank migration was measured downstream, leaving the rock deflectors installed to protect the bank in mid-stream. As indicated by the change in channel morphology at the downstream reach, it is apparent that the rock deflectors were ineffective at adequately protecting the bank from erosion. Particle distributions in both reaches, in general, became more fine over most of the monitoring period, with the exception of the 2006 assessment, which showed coarsening in the $15^{\text {th }}$ and $50^{\text {th }}$-percentile size categories at the upstream reach. There was no evidence of deposition associated with the coarsening of the upstream reach in 2006, indicating transport capability was maintained or increased. The trend toward a finer particle 
distribution in the downstream reach suggests a decrease in sediment transport commonly associated with channel widening.

Because of replacement plantings in 2001 and 2002, the most reliable time frame for interpretation of trends in the number and well being of riparian plantings is 2003-2006. The most prevalent tree species in 2003 was Platanus occidentalis (sycamore; 63 individuals), followed by Carpinus caroliniana (ironwood; 35), Quercus palustris (pin oak; 33), Alnus serrulata (smooth alder; 30), Acer rubrum (red maple; 26), Acer saccharinum (silver maple; 17), and Sal. nigra (10). The most prevalent shrubs in 2003 were Cornus spp. (98 individuals), followed by Salix discolor (pussy willow; 51), Physocarpus opulifolius (ninebark) and Viburnum dentatum (arrowood) (each with 28 individuals), Clethra alnifolia (summersweet; 27), and Spirea virginiana (Virginia spirea; 4). Trees and shrubs that appreciably declined in number between 2003 and 2006, including Sal. nigra, Al. serrulata, Ac. saccharinum, $\mathrm{Sa}$. discolor, and $\mathrm{Cl}$. alnifolia, generally exhibited more stress in 2003 compared to their counterparts that remained nearly constant or increased in number throughout the study. Despite replacement of dead individuals in 2001 and 2002, planted trees decreased from 214 in 2001 to 171 in 2006 and shrubs decreased from 546 in 2001 to 225 in 2006 . By contrast, the combined number of the two most prevalent non-planted species [Acer negundo (box elder) and Gymnocladus dioicus (Kentucky coffee tree)] more than doubled over the same time period (from 110 to 244 individuals). The density of planted species at the end the study was 382 plants per acre compared to 329 plants per acre for non-planted species.

\section{Introduction}

Maintenance and improvement of transportation infrastructure commonly necessitate alteration of existing stream channels and (or) naturally occurring wetlands. Compensatory mitigation for wetland and stream encroachments usually is required by Federal and State regulatory agencies and commonly includes modification or construction of wetlands, stream channels, and associated riparian buffers. From 1998 through 2003, the Pennsylvania Department of Transportation (PennDOT) made roadway improvements to $5.5 \mathrm{mi}$ of U.S. Highway 202 in Chester and Montgomery Counties, Pa. (fig. 1). Pursuant to Section 404 of the Clean Water Act, PennDOT was granted Federal and State permits to permanently impact naturally occurring wetlands and to enclose selected stream reaches including an unnamed tributary that drains to Valley Creek. To compensate for these authorized activities, a Federal Section 404 permit required PennDOT to construct at least 0.29 acre of emergent wetland and 0.94 acre of scrub-shrub/forested wetland and to modify a reach of Valley Creek that flows through Valley Forge National Historical Park (Valley Forge Park).
Wetland construction began in March 2000 and culminated with final grading and planting in May 2000. In addition, approximately 0.70 acre of natural wetland adjacent to the constructed wetland was enhanced with plantings of native shrubs and trees. The constructed wetland and enhanced natural wetland collectively are referred to as the wetlandcompensation site. Stream modifications included shrubs and trees planted from October through December 2000 throughout a riparian buffer adjacent to Valley Creek and stabilization structures installed within the active channel in the spring of 2001.

In accordance with project permits and additional guidance issued by the U.S. Army Corps of Engineers (ACOE) to PennDOT and Tredyffrin Township, monitoring of the constructed wetland and stream modifications was conducted over seven consecutive growing seasons. The U.S. Geological Survey (USGS), in cooperation with PennDOT, collected data from 2000 through 2006 to quantify changes in 1) the vegetation, soils, and extent of the constructed wetland, 2) the profile, dimension, and substrate in the vicinity of stabilization structures placed in Valley Creek, and 3) the woody vegetation within the planted riparian buffer. These data provide PennDOT and ACOE with the information needed for them to assess the success of each project component.

Monitoring conditions and guidance specified in project permits require collection of quantitative and qualitative data. The data-collection methods used for this study were adapted from an approach recently (2000-2004) utilized by USGS (Chaplin and others, 2006) to monitor a relocated stream reach, constructed wetland, and riparian buffer in Lehigh County, Pa., approximately $50 \mathrm{mi}$ north of the study area. Use of a consistent approach for data collection and storage enhances the ability to transfer results among other similar projects. Additional activities and associated methods that may be considered for future investigations include, but are not limited to, protocols for documentation of benthic-invertebrate communities, habitat, and (or) water quality as dictated by project objectives.

\section{Purpose and Scope}

This report presents a summary of data collected within a constructed wetland and a modified stream reach of Valley Creek during seven post-construction monitoring events between October 2000 and September 2006. This report provides PennDOT and ACOE with the information needed for them to determine the success of the constructed wetland, the stabilization structures placed in Valley Creek, and the riparian plantings adjacent to the creek. In general, the measure of success for the project components is ambiguously defined and is open to interpretation by government agencies with a regulatory mandate. Therefore, it is beyond the scope of this report to define success or to determine if the objectives of wetland construction or stream modification were successfully met. 

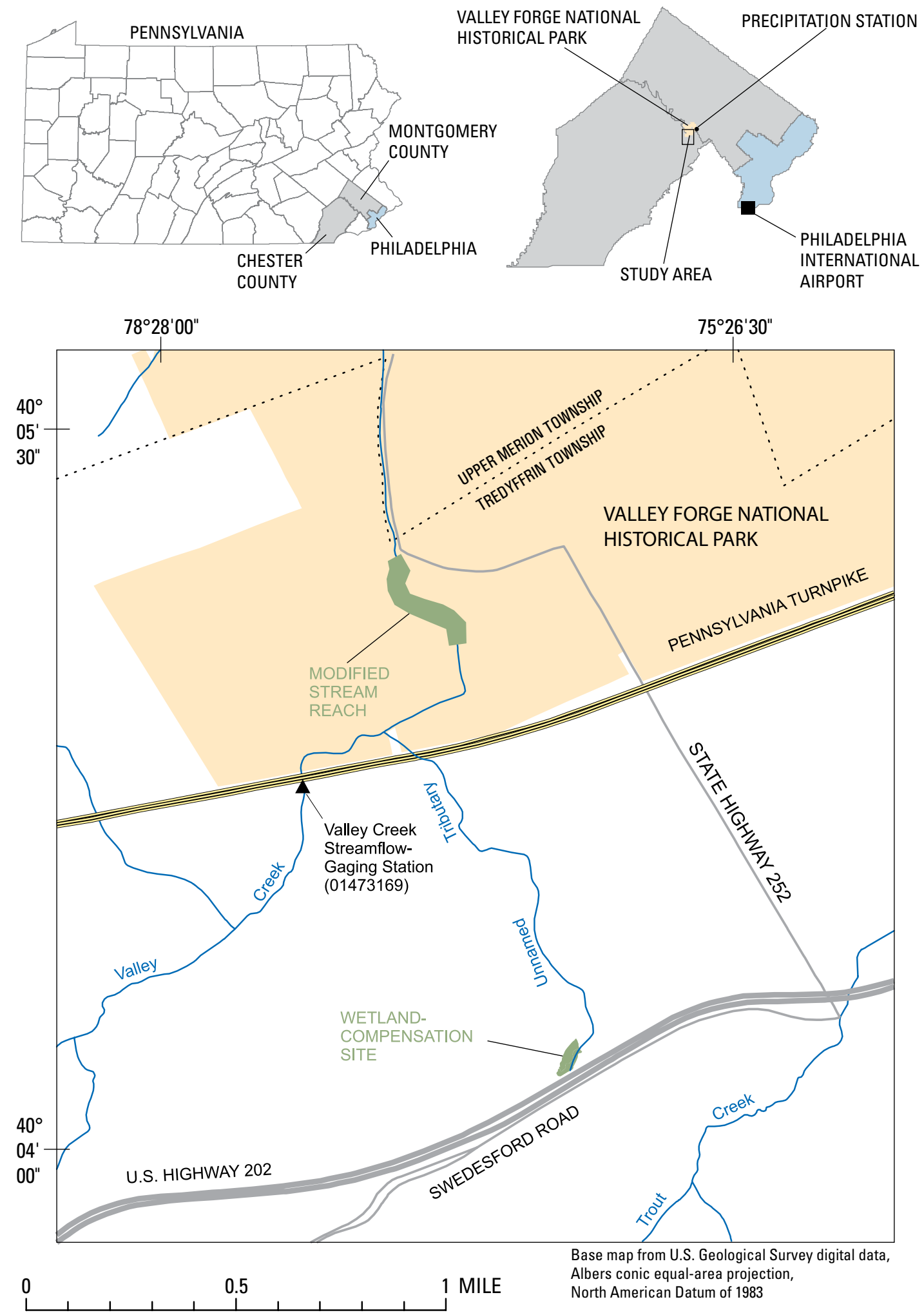

Figure 1. Location of the wetland-compensation site and modified stream reach, Tredyffrin Township, Chester County, Pennsylvania. 
Areal cover of vegetation, hydric-soils indicators, water levels, and the areal extent of the constructed wetland are presented. Changes to the profile, dimension, and substrate at selected locations along the modified stream reach were quantified by longitudinal and cross-section surveys and pebble counts. The density, condition, and richness of woody vegetation growing in planted areas of the riparian buffer also are presented. Photographs of the wetland and modified stream reach provide a graphic record of changes throughout the study period.

\section{Description of the Study Area}

The study area is in Chester County, Pa., and consists of the wetland-compensation site adjacent to U.S. Highway 202 and sections of a 1,600-ft reach of Valley Creek that was modified with riparian plantings and rock placed to deflect flow (rock deflectors) and minimize erosion (fig. 1). All components of the study area are within the Lowland Section of the Piedmont Physiographic Province, which is characterized by broad valleys separated by broad low hills (Pennsylvania Department of Conservation and Natural Resources, 2000). The underlying bedrock is dominated by limestone and dolomite with some shale and sandstone (Sevon, 2000). Although karst features are common throughout much of the Piedmont, none were observed in or near the wetland-compensation site or modified stream reach.

\section{Wetland-Compensation Site}

The two components of the wetland-compensation site are the constructed wetland and the adjacent natural wetland that was enhanced with tree and shrub plantings in 2000 (fig. 2). The focus of the monitoring was on the constructed wetland that encompasses at total of 1.36 acres characterized by 0.42 acre dominated by emergent herbaceous vegetation (termed the emergent (EM) part) and 0.94 acre dominated by planted and non-planted trees and shrubs (termed the scrubshrub/forested ( $\mathrm{SS} / \mathrm{FO}$ ) part). The constructed wetland is bounded to the south by a berm for U.S. Highway 202 and on the west and north by a steeply sloping terrace (fig. 3 ). The boundary between the constructed wetland and the enhanced natural wetland is defined by the limit of excavation during construction. To the east, the boundary is a human-made rip-rap and earth berm that parallels Wilson Road (fig. 2). The berm is approximately $2-3 \mathrm{ft}$ higher than the wetland surface and has three outlets of lower elevation (about $1.5 \mathrm{ft}$ higher than the wetland surface).

The primary source of water for the wetland is stormwater that enters through a rip-rapped stormflow channel near the southwest corner and through a culvert near the southeast corner, along with base flow and stormflow from an intermittent unnamed tributary conveyed under U.S. Highway 202 by a box culvert (fig. 2). Water is detained by the berm along the east side, periodically submerging the wetland-compensation site. The unnamed tributary flowing through the site ultimately connects with Valley Creek approximately $1,700 \mathrm{ft}$ upstream from the upstream terminus of the modified stream reach (fig. 1).

Native soils within the wetland-compensation site are predominantly Lindside Silt Loam (soil map unit Ln), a moderately well-drained soil with slopes of 0 to 3 percent (Natural Resources Conservation Service, 2008). Lindside Silt Loam is a common soil type on floodplains in the area, and it extends approximately $165 \mathrm{ft}$ on either side of the unnamed tributary. Native soils in the western quarter of the site are Conestoga Silt Loam [soil map unit CtC, Natural Resources Conservation Service, 2008; formerly described as Hagerstown Silt Loam in previous soil surveys by Kunkle (1963)]. Native Conestoga Silt Loam soils are steeper (8 to 15 percent slopes) than Lindside Silt Loam soils, but flattening of the slopes during wetland construction resulted in 0 to 3 percent slopes when construction was complete. Soil profiles within and outside of the boundary of the constructed wetland were disturbed when the native soils were excavated. Amendments, including mulched leaves and topsoil, were added to the surface and mixed with native soils before planting (URS Greiner Woodward Clyde, 1999a).

Upon completion of wetland construction and soil preparation from March to May 2000, the EM part of the wetland was planted with a mixture of nine emergent species including Agrostis alba ${ }^{1}$ (redtop), Aster novae-angliae (New England aster), Eupatorium purpureum (joe pye weed), Eupatorium perfoliatum (common boneset), Juncus effusus (soft rush), Lobelia cardinalis (cardinal flower), Scirpus cyperinus (wool grass), Scirpus validus (great bulrush), and Verbena hastata (blue vervain) (URS Greiner Woodward Clyde, 1999a). At the same time, the SS/FO part was planted with trees and shrubs including Acer rubrum (red maple), Quercus palustris (pin oak), Quercus bicolor (swamp white oak), Acer saccharinum (silver maple), Salix nigra (black willow), Viburnum dentatum (arrowood), Ilex verticillata (winterberry), Cornus amomum (silky dogwood), Cornus racemosa (gray dogwood), and Cornus stolonifera (red-osier dogwood).

\section{Modified Stream Reach}

The modified stream reach is approximately 1 straightline mile north of the wetland-compensation site and lies within Valley Forge Park (fig. 1). The reach extends for a length of approximately $1,600 \mathrm{ft}$ and has partially wooded banks. The channel through this reach generally is free to adjust, with few countermeasures that would prohibit lateral or vertical migration. The area draining to the downstream terminus of the reach is $22.6 \mathrm{mi}^{2}$; the underlying lithology is

\footnotetext{
${ }^{1}$ When plant names are first introduced in the body of this report, the genus and species are both spelled out. For subsequent use, the generic names are abbreviated, followed by the full species name. When a plant could not be identified down to the species level, species is abbreviated with "sp." When referring to multiple species in the same genus, species is abbreviated with "spp."
} 


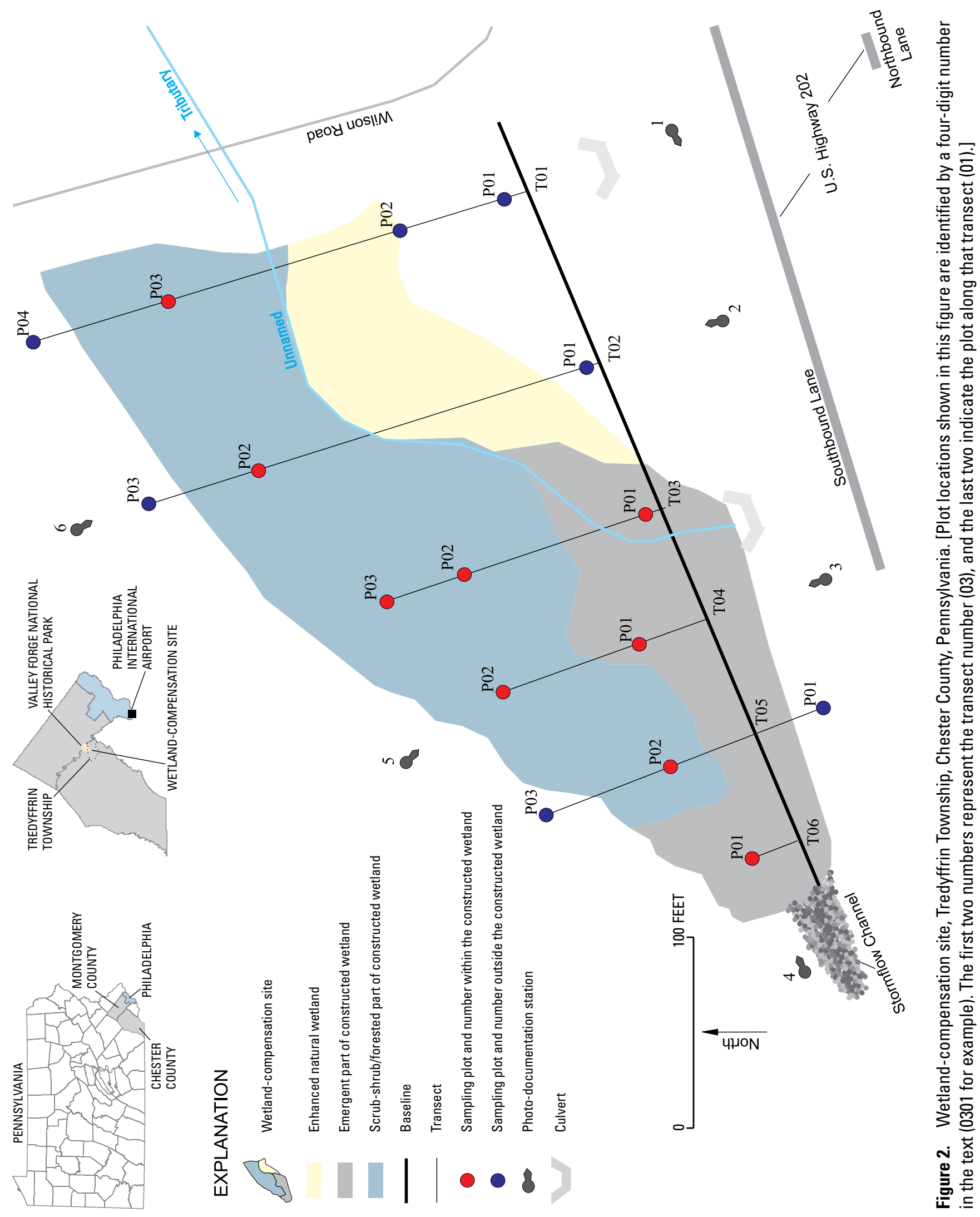



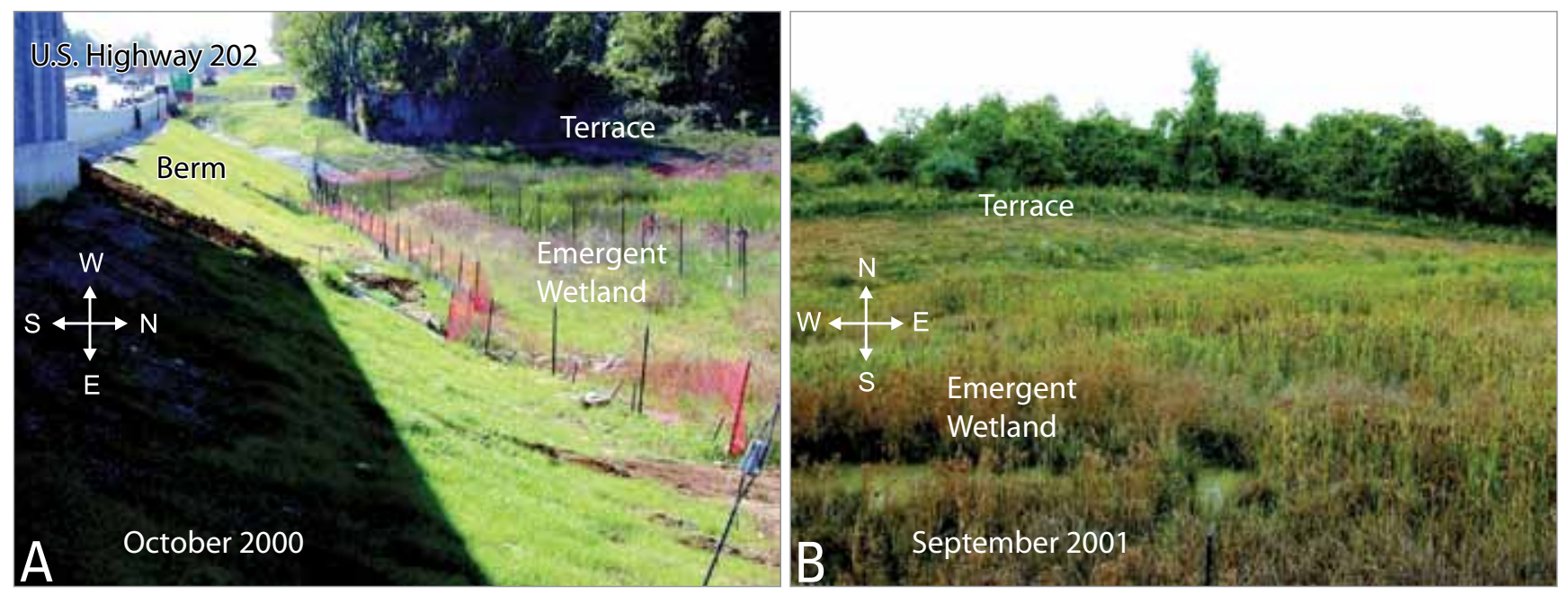

Figure 3. Views of a berm for U.S. Highway 202 (A) and a terrace (A and B) that bound the constructed wetland to the south, west, and north.

dominated by carbonate bedrock (approximately 68 percent; Pennsylvania Department of Conservation and Natural Resources, 2000), and the land use is varied (Price and others, 2003). Approximately 41 percent of the watershed is used for urban development (including high- and low-intensity residential uses and commercial, industrial, and transportation uses), and 35 percent is forested (including deciduous, evergreen, and mixed-forest types).

Modifications to Valley Creek consist of instream stabilization structures and riparian plantings. The stabilization structures were placed at two locations on the right bank (as one looks downstream) in the spring of 2001 (fig. 4). The downstream structure consists of limestone rock deflectors with diameter of about $2 \mathrm{ft}$ aligned in a downstream orientation. The upstream structures consists of two rows of rock deflectors aligned in similar fashion, with a fibrous, tubular matte at the toe of the bank behind and between the two rows. At the upstream location, a nearby swale lined with rip-rap conveys runoff to Valley Creek (fig. 4).

Between October and December 2000, trees and shrubs were planted in 34 groups of mixed species along the modified stream reach (fig. 4). The total number of trees and shrubs was dictated by special conditions in project permits that required a minimum density of 425 acceptable shrubs or trees per acre (planted and acceptable non-planted species). To deter browsing by deer and other herbivores, the groups were enclosed by plastic fencing that extended for a height of about $10 \mathrm{ft}$. Species initially planted in 2000 included Ac. rubrum, Ac. saccharinum, Alnus serrulata (smooth alder), Platanus occidentalis (sycamore), Q. palustris, Sal. nigra, Carpinus caroliniana (ironwood), Clethra alnifolia (summersweet), Co. amomum, Co. racemosa, Co. stolonifera, Physocarpus opulifolius (ninebark), and Vi. dentatum.

As a result of plant-replacement guarantees in the project contracts, some trees and shrubs that died after planting were re-planted in October 2001 and two additional times in 2002.
The re-planted species included $P l$. occidentalis, Sal. nigra, Al. serrulata, Cl. alnifolia, Ca. caroliniana, Ac. rubrum, Co. stolonifera, Salix discolor (pussy willow), and Co. amomum. $\mathrm{Cl}$. alnifolia and $\mathrm{Ca}$. caroliniana were used to replace dead Ph. opulifolius plants during the 2002 plantings.

\section{Monitoring Methods}

In accordance with project-permit requirements, USGS developed and implemented monitoring plans designed to quantify changes in 1) the vegetation and soils in the constructed wetland; 2) the profile, dimension, and substrate at selected locations along the modified stream reach; and 3) the planted and non-planted woody-vegetation communities growing within the riparian buffer. The data needed to meet these objectives are varied, requiring adaptation of methods from multiple sources into a consistent approach. Methods for monitoring the wetland largely are from the wetland-delineation manual published by the ACOE Environmental Laboratory (1987) and vegetation sampling protocols described by Fitzpatrick and others (1998). The modified stream reach was monitored following methods adapted from Rosgen (1996), Dunne and Leopold (1978), and Wolman (1954). For the riparian buffer, there was no need to select a specific method designed to sample a representative portion of the population because plants within all pre-defined groups were identified and counted.

Many plants generally are easier to identify at the end of the growing season (fall), because leaves, stems, and, most importantly, reproductive parts are mature. As a result, monitoring of each component was scheduled for the fall, with the exception of an assessment of the modified stream reach in June 2001 to document baseline conditions subsequent to installation of rock deflectors. Monitoring of the constructed 


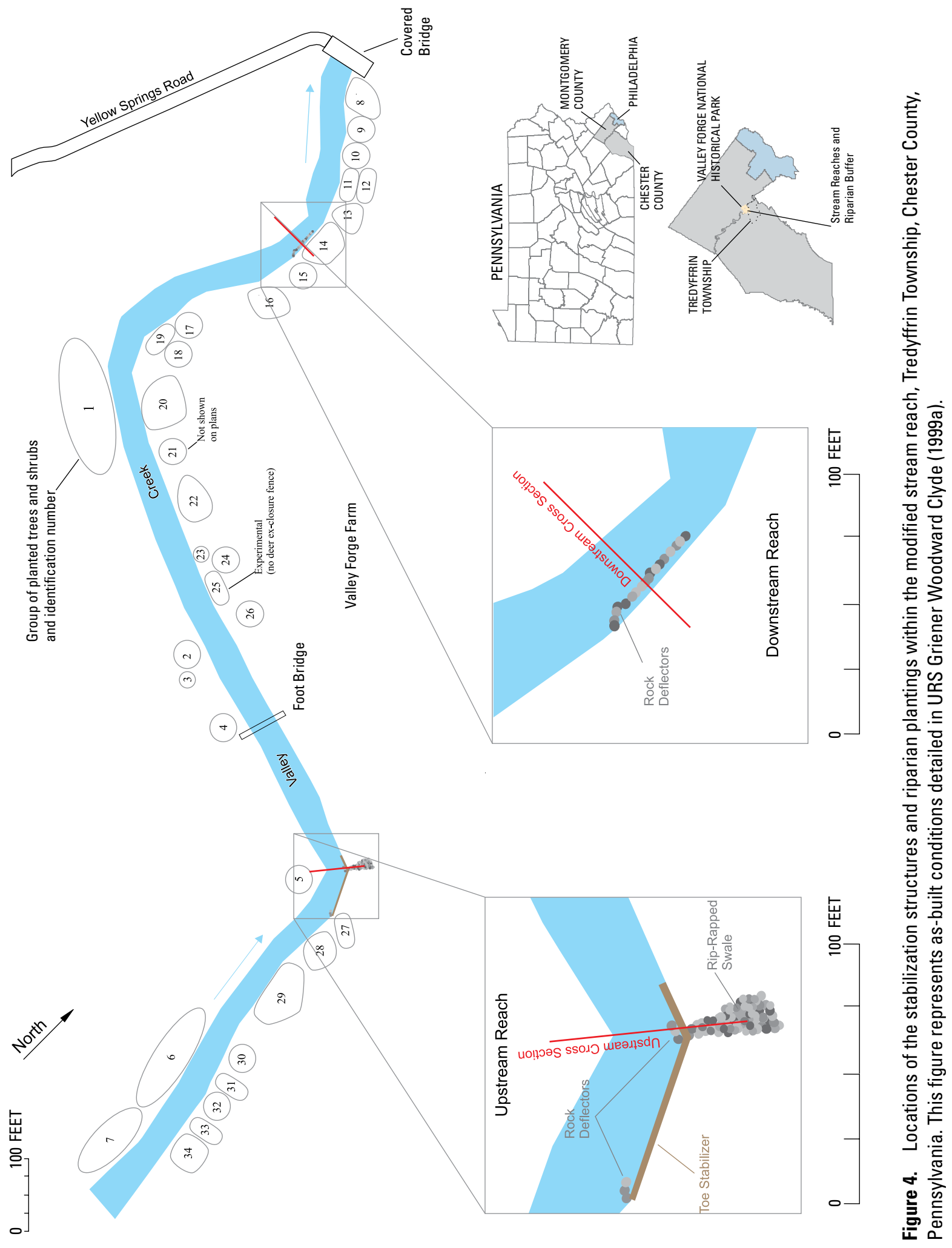


wetland began in October 2000 and concluded in September 2006 (table 1). The riparian buffer was planted between October and December 2000 and was monitored each fall from September 2001 to September 2006.

\section{Wetland-Compensation Site}

For the purposes of this report, a wetland is defined as an area inundated or saturated by water at a frequency and duration sufficient to support a prevalence of vegetation adapted for life in saturated-soil conditions (U.S. Army Corps of Engineers Environmental Laboratory, 1987). Frequent and (or) extended periods of saturation lead to a reducing environment that causes chemical reduction of some soil components (like iron and manganese oxides). Reducing conditions result in soil colors and other physical characteristics indicative of wetland or hydric soils. Hydric soils limit the growth of many plants but favor hydrophytic species adapted to grow in wetlands. Thus, vegetation and soil characteristics, along with evidence of frequent and persistent inundation, were used to delineate 1.36 acres of constructed wetland ( 0.42 acre of EM wetland and 0.94 acre of SS/FO wetland). The extent of the constructed wetland was computed as the area surrounded by the delineated boundaries (fig. 2). The boundaries were surveyed by standard land-survey techniques using a Nikon DTM 750 Total Station.

In October 2000, a baseline was established using a compass to sight a bearing parallel to the long axis of the wetland-compensation site (fig. 2). At this time, five transects perpendicular to the baseline were established to create a grid. Monumented sampling plots were then established along the grid to provide a representative vegetation sample. In fall 2002, transect number 6 and three additional sampling plots (two along transect 3 and one along transect 6; fig. 2) were added to the monitoring grid to provide additional representation of emergent and woody vegetation. Throughout this report, locations of the sampling plots are described by a fourdigit number (0301, for example) where the first two numbers (03) indicate the transect and the last two numbers indicate the plot number along that transect (01). The locations of the sampling plots that were added to the monitoring grid in fall 2002 are 0302,0303 , and 0601 . Along with the sampling plots, six photo-documentation stations were established (fig. 2) in
October 2000 to provide for visual comparison of site conditions over time. Vegetation, soil, and hydrology data were collected by methods described below.

Areal cover of vegetation in the constructed wetland was estimated visually within the 16 circular sampling plots (fig. 2) having a radius of $15 \mathrm{ft}$. Plants within the plots were identified to species, and their areal cover (expressed as a percentage of total plot area), stratum, and indicator status [which reflects the range of estimated probabilities of a species occurring in wetland areas versus non-wetland areas (Reed, 1988)] were determined. Note that total areal cover of vegetation may exceed 100 percent because 1) most plant communities consist of two or more vegetative strata; 2) areal cover is estimated by vegetative stratum; and 3 ) foliage within a single stratum may overlap (U.S. Army Corps of Engineers Environmental Laboratory, 1987).

By definition, a plant community growing within a wetland is hydrophytic (U.S. Army Corps of Engineers Environmental Laboratory, 1987). A vegetation community is considered hydrophytic when greater than 50 percent of the dominant species have an indicator status of Obligate-wetland (OBL), Facultative-wetland (FACW), or Facultative (FAC) (U.S. Army Corps of Engineers Environmental Laboratory, 1987). The indicator status of each identified species in the constructed wetland was obtained from the National List of Plant Species that Occur in Wetlands Region I-Northeast (Reed, 1988). Reed (1988) categorizes plants according to the probability that a given species grows in a wetland. OBL species almost always grow solely in wetlands (estimated probability greater than 99 percent). FACW species usually grow in wetlands (estimated probability 67-99 percent) but occasionally grow in non-wetlands. FAC species grow in wetlands roughly half of the time (estimated probability 34-66 percent). Facultative-upland species (FACU) occasionally grow in wetlands (estimated probability $1-33$ percent) but usually grow in non-wetlands, and Upland species (UPL) grow in nonwetlands. A plus after the category (such as FAC + ) indicates a frequency of occurrence in the upper end of the probability range, whereas a minus indicates a frequency of occurrence in the lower end of the range (Tiner, 1999).

Dominant species were determined by the $50 / 20$ rule described by the U.S. Army Corps of Engineers Environmental Laboratory (1987). Under this rule, a species can be

Table 1. Summary of dates for data collection at the constructed wetland and modified stream reach, Tredyffrin Township, Chester County, Pennsylvania.

$[-$, no monitoring $]$

\begin{tabular}{lcllllll}
\hline & \multicolumn{7}{c}{ Monitoring dates } \\
\cline { 2 - 7 } & \multicolumn{1}{c}{$\mathbf{2 0 0 0}$} & \multicolumn{1}{c}{$\mathbf{2 0 0 1}$} & \multicolumn{1}{c}{$\mathbf{2 0 0 2}$} & $\mathbf{2 0 0 3}$ & $\mathbf{2 0 0 4}$ & \multicolumn{2}{c}{$\mathbf{2 0 0 5}$} \\
\hline Constructed wetland & Oct. 10-11 & Sept. 27-28 & Sept. 17, 19 & Sept. 25 & Sept. 7-8 & Sept. 6 & Sept. 12 \\
Stream channel & - & June 18, Sept. 10 & Sept. 11 & Sept. 22 & Sept. 10 & Sept. 12 & Sept. 18 \\
Riparian buffer & - & Sept. 28 & Sept. 18-19, 23 & Sept. 26 & Sept. 7 & Sept. 7 & Sept. 13 \\
\hline
\end{tabular}


considered dominant at two levels. At the first level, areal cover for individual species is compared to 50 percent of the total cover. Areal-cover percentages for individual species are added, starting with the species providing the most cover and working down, until 50 percent of the total cover is equaled or exceeded. Those species necessary to exceed 50 percent of the total areal cover are considered dominant. At the second level, species that did not already qualify as dominant but exceed 20 percent of the total areal cover also are considered dominant.

Indicators of wetland hydrology, following guidance in the ACOE Wetland Delineation Manual (U.S. Army Corps of Engineers Environmental Laboratory, 1987), were documented at all sampling plots. Indicators were assessed within each sampling plot and include inundation, free water in a soil-sampling pit, saturated soils, drainage patterns, and oxidized root channels.

Soil profiles were examined to a depth of at least $12 \mathrm{in}$., or to the depth of refusal, in a soil pit dug within the boundaries of each sampling plot. Soil-matrix color, mottles, texture, and structure were determined with Munsell Soil Color Charts (Munsell Color, 2000). Each soil horizon was evaluated for hydric-soil indicators, which include evidence of histosol (organic) or histic epipedon soils, sulfidic odor, aquic moisture regime, gleyed or low-chroma colors, concretions, high organic content in the surface layer in sandy soils, and organic streaking in sandy soils (U.S. Army Corps of Engineers Environmental Laboratory, 1987). Chroma refers to the strength of the soil color (Munsell Color, 2000), and low-chroma colors within the "B" horizon are indicative of a fluctuating water table that causes periodic chemical reduction (U.S. Army Corps of Engineers Environmental Laboratory, 1987).

\section{Stream Reach Surveys}

Two discrete reaches of Valley Creek, where rock deflectors were installed, were selected for monitoring. These reaches are referred to as the upstream reach and downstream reach shown in figure 4 . Both sets of rock deflectors are intended to protect the adjoining banks from continued erosion. Each reach is about $100 \mathrm{ft}$ in length and extends beyond the upstream and downstream extent of the deflectors. Surveyed distances are measured along the main flow path (thalweg) of the stream. The stream thalweg and water surface were surveyed to characterize the profile of the channel within the vicinity of each cross section. For surveys of the downstream reach from 2003 to 2006, the channel profile was extended farther downstream (compared to surveys in 2001 and 2002) to better characterize a relatively deep pool. For the purposes of this report, right and left sides of the stream channel are determined as if looking downstream. Reported elevations are based on an arbitrary datum and have no relation to any other established datum.

For the sake of a uniform comparison, cross-sectional channel geometries were determined for the areas bounded by re-bar monuments, which were placed beyond the active channel in an attempt to minimize vulnerability to bank erosion. The monuments provide definitive end points within which evolving channel widths, mean depths, and areas within cross sections can be compared. The area bounded by these monuments contains, but is not limited to, the active channel. After the fall 2005 assessment and prior to the 2006 assessment, the monument marking the right end of the downstream cross section was destroyed as a result of bank erosion. To conform to the approach used for previous assessments, the cross-section survey was extended just beyond the top of the right bank so the geometry of the enlarged channel could be quantified and compared to previous assessments. Cross-section locations (fig. 4) were selected to define the channel characteristics at the point of maximum channel constriction resulting from the rock placement. All cross sections are oriented perpendicular to the centerline of the channel.

Two 3-ft pieces of reinforcing bar that were 0.5 -in. in diameter (bank pins) were inserted horizontally into the eroding bank within each cross section until the proximal tip of the bar was flush with the bank surface. One bank pin was inserted about $1 \mathrm{ft}$ from the base of the streambank, the other about $1 \mathrm{ft}$ or $2 \mathrm{ft}$ above. For the upstream cross section, the amount of bank recession (erosion) was quantified by the amount of the pin exposed between site visits. Bank pins at the downstream cross section were lost as a result of bank erosion. As a result, the total amount of bank recession (erosion) at this cross section was quantified by bank-pin exposure from 2001 to 2005 plus erosion documented in cross-section surveys between 2005 and 2006.

Pebble counts (Wolman, 1954) were conducted to quantify the particle distribution within each cross section. The quantification of the bed substrate is used to determine changes to the material being transported or deposited through each reach. Pebble counts do not extend the full distance between monuments but are instead confined within fixed cross-section end points. Particle distributions are extracted

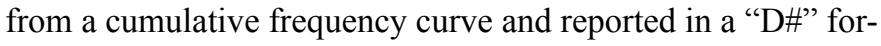
mat where \# is the percentage of particles with an intermediate axis less than or equal to the reported value.

Photographic documentation was conducted for use as a comparative tool between assessments. A minimum of five photographs was taken at each cross section to provide a visual record of the site during the time of the assessment. Photographic locations for each cross section include 1) upstream from the cross section looking downstream, 2) downstream from the cross section looking upstream, 3) standing at the right cross-section monument looking toward the left bank, 4) standing at the left cross-section monument looking toward the right bank, and 5) the vicinity of the rock deflectors. 


\section{Riparian Buffer}

Most groups of trees and shrubs (fig. 4) were protected with deer-exclosure fencing installed according to stream enhancement plans developed for PennDOT (URS Greiner Woodward Clyde, 1999a). The fencing was intended to minimize browsing but not stop it all together. Group 25 was intentionally not enclosed with fencing as an informal test to determine the amount of browsing by deer on unprotected plants. Planted and non-planted trees and shrubs within each group were identified and counted by visual inspection. Each individual, planted or non-planted, was characterized as alive, stressed $^{2}$, and (or) browsed ${ }^{3}$ through visual inspection. Note that these categories are not mutually exclusive. For example, an individual that is alive but stressed because of browsing would be characterized as alive, stressed, and browsed.

Density was determined by dividing the total number of individuals in all the groups by the total planted area (1.06 acres). The planted area was calculated from the dimension and number of tree and shrub groups in the streamenhancement plans developed by URS Greiner Woodward Clyde (1999b). Selected groups were photographed each fall to compile a visual record for comparison over time.

\section{Physical and Vegetative Results}

Disturbance of wetland and fluvial systems sets the stage for dramatic responses - intended or otherwise. For example, excavation of the wetland-construction site may expose longdormant yet viable seed banks, in addition to altering preexisting morphology. Application of topsoil and leaf-mulch amendments also has the potential to introduce new plant species. Streambank-stabilization features like the rock deflectors placed in Valley Creek have little potential for direct effect on vegetation; however, they alter flow patterns and may protect the streambanks or accelerate adjustments in the stream channel. Planting of riparian buffers along streams commonly is attempted to complement countermeasures such as rock deflectors (Palone and Todd, 1997; Rosgen, 1996). However, climatic conditions during and after planting, along with species selection and placement, have a large influence on survival of plants and the ultimate effectiveness of riparian plantings in support of countermeasures. Construction practices in the wetland and stream, plant selection, preexisting conditions, and climate are all factors that influenced the physical and vegetative characteristics discussed in the sections below.

${ }^{2}$ Plants that have no foliage, discolored foliage, or malformed fruiting structures.

${ }^{3}$ Plants damaged from feeding by deer or other herbivores.

\section{Constructed Wetland}

When the constructed wetland was first monitored in October 2000, differences in vegetation growing in the EM and SS/FO parts were more subtle than the distinctions that eventually developed. Both parts of the wetland initially were dominated by herbaceous communities in fall 2000, despite the tree and shrub plantings in the SS/FO part. The herbaceous community persisted in the EM part with some shifts in species composition throughout the study. By contrast, a thick canopy of trees and shrubs developed by fall 2005 in the SS/FO part, allowing only the most shade-tolerant herbaceous species to inhabit the understory. Even though vegetation type and species composition differed through time, the EM and SS/FO parts both supported hydrophytic plant communities throughout the study period (table 2). The boundary between $\mathrm{EM}$ and SS/FO parts also remained consistent.

Areal cover in the EM part ranged from 101 to 139 percent (fall 2001 and fall 2000, respectively) and was 135 percent in fall 2006 (table 2). Annual water-level measurements in plots 0301 and 0601 (fig. 5) and hydric-soil indicators (table 3) suggest inundation or soil saturation within 12 in. of the soil surface initially was common, even in 2001 and 2002, a period of severe drought (Northeast Region Climate Center, 2007b) (table 4). Frequent and long-lasting saturation in the root zone (upper 12 in. of soil) favors OBL species like Typha latifolia (broadleaf cattail) and Sc. validus (great bulrush), which maintained dominance in the EM part throughout the study (table 2). Sc. validus was the only planted herbaceous species that provided appreciable cover because it was best suited to effectively compete with Ty. latifolia (table 2). Other planted species either did not germinate or were not able to complete with Ty. latifolia and Sc. validus. In fall 2000, the end of the first growing season, Sc. validus contributed the greatest cover (43 percent), followed by Ty. latifolia (broadleaf cattail; 30 percent), Ag. alba (23 percent), Lotus corniculatus (bird's foot trefiol; 13 percent), and J. effusus (soft rush; 10 percent). Cover by $S c$. validus remained fairly constant for 5 consecutive years, ranging from 37 to 45 percent between 2000 and 2004. During this same time frame, cover by Ty. latifolia was steadily increasing from 30 percent in 2000 to 63 percent in 2004 and eventually to 80 and 78 percent in 2005 and 2006, respectively. Ty. latifolia effectively displaced Sc. validus, which contributed only 20 percent cover in the last 2 years of the study. Other species in the EM part were sparingly present throughout the study, struggling to compete with Ty. latifolia and Sc. validus (table 2). By 2006, Impatiens capensis (jewelweed) and Agrostis stolonifera (spreading bentgrass) were the third and fourth most common species contributing 17 and 10 percent areal cover, respectively.

Areal cover in the SS/FO part (table 2) ranged from 97 percent in 2001 to 146 percent in 2000 and was 139 percent in 2006. In 2000 and 2001, the SS/FO part was dominated by Echinocloa crusgalli (barnyard grass), an annual invasive from Eurasia (Rhoads and Block, 2000) that grew up to $5 \mathrm{ft}$ tall. The establishment of Ec. crusgalli is indicative of the 


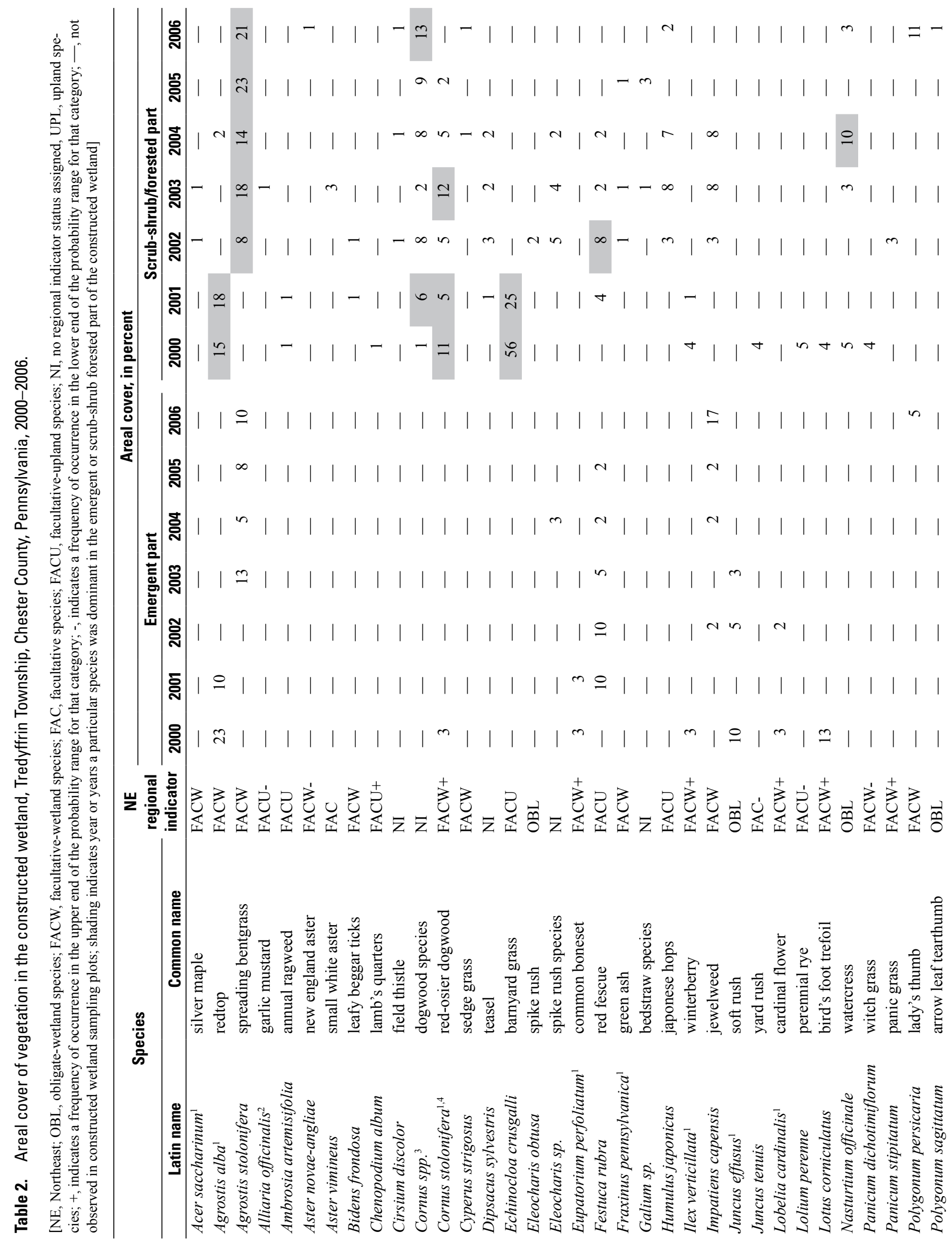




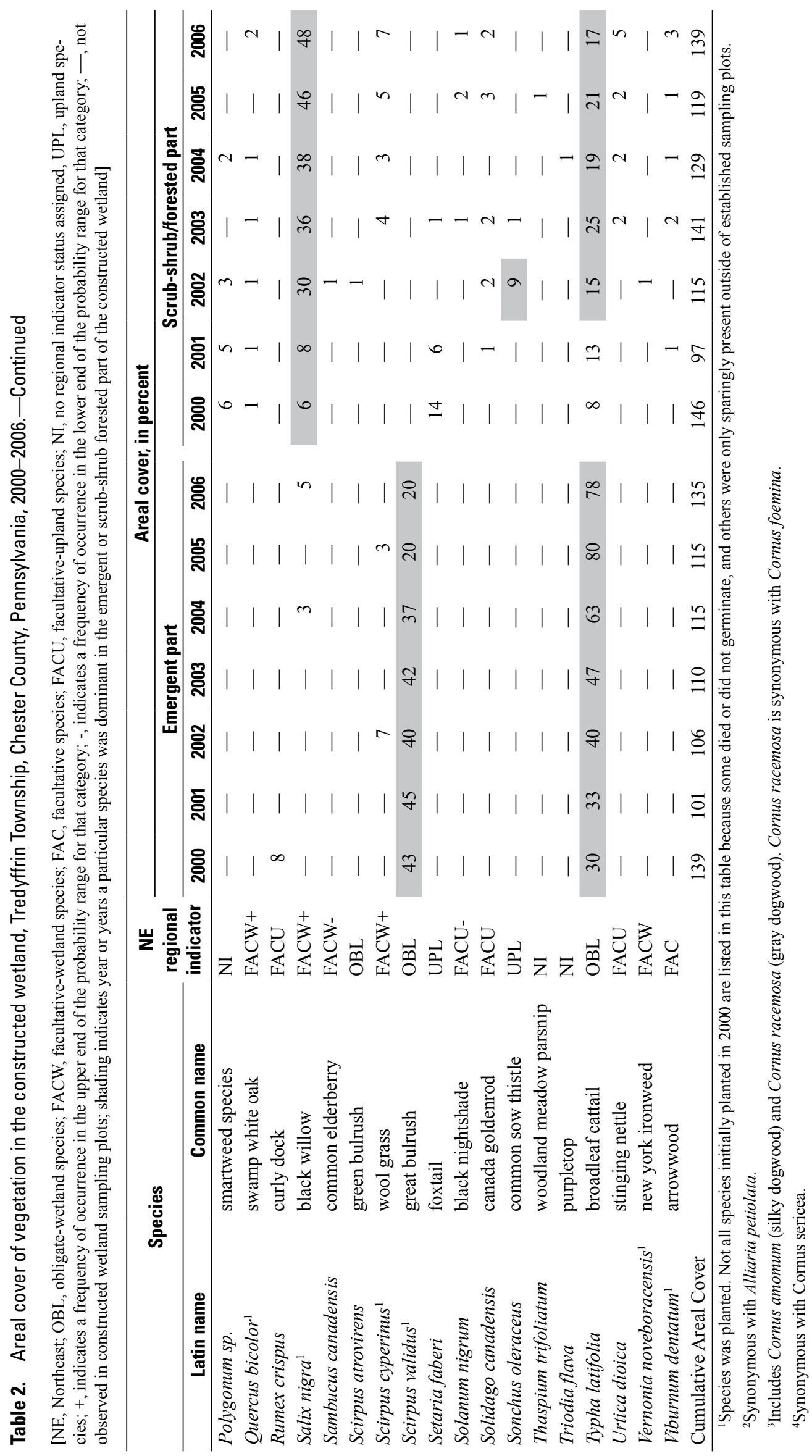




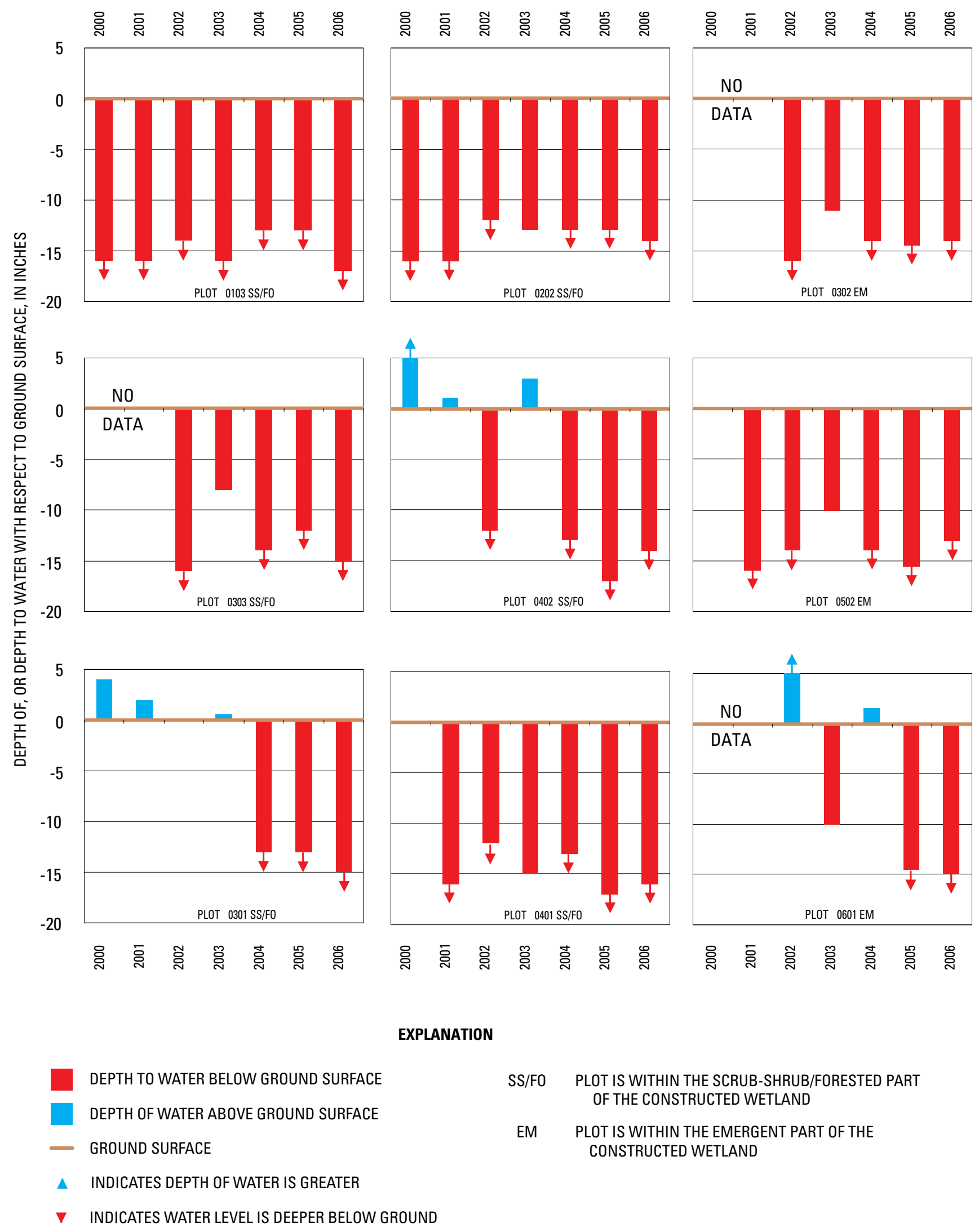

Figure 5. Water levels at sampling plots within the constructed wetland, Tredyffrin Township, Chester County, Pennsylvania, 20002006. [Plot locations are shown on figure 2 . The first two numbers of the plot location $(0301$, for example) represent the transect number (03), and the last two indicate the plot along that transect (01).] 
Table 3. Observations of hydric-soil indicators in the constructed wetland, Tredyffrin Township, Chester County, Pennsylvania, 2000-2006.

[SS/FO, scrub-shrub/forested; EM, emergent; ND, no data collected; shading denotes hydric-soil indicators were present]

\begin{tabular}{cccccccc}
\hline Plot $^{1}$ & Designation $^{2}$ & $\mathbf{2 0 0 0}$ & $\mathbf{2 0 0 1}$ & $\mathbf{2 0 0 2}$ & $\mathbf{2 0 0 3}$ & $\mathbf{2 0 0 4}$ & $\mathbf{2 0 0 5}$ \\
\hline 0103 & $\mathrm{SS} / \mathrm{FO}$ & & & & & \\
0202 & $\mathrm{SS} / \mathrm{FO}$ & & & & \\
0302 & $\mathrm{SS} / \mathrm{FO}$ & $\mathrm{ND}$ & $\mathrm{ND}$ & & \\
0303 & $\mathrm{SS} / \mathrm{FO}$ & $\mathrm{ND}$ & $\mathrm{ND}$ & & \\
0402 & $\mathrm{SS} / \mathrm{FO}$ & & & & \\
0502 & $\mathrm{SS} / \mathrm{FO}$ & & & & \\
0301 & $\mathrm{EM}$ & & & & \\
0401 & $\mathrm{EM}$ & & & & \\
0601 & $\mathrm{EM}$ & $\mathrm{ND}$ & $\mathrm{ND}$ & & \\
\hline
\end{tabular}

${ }^{1}$ Plot locations are shown on figure 2 . The first two numbers of the plot location (0301, for example) represent the transect number ( 03 ) and the last two indicate the plot along that transect (01).

${ }^{2}$ In September 2000, areas of the constructed wetland planted with an abundance of trees and shrubs were designated scrub-shrub/forested (SS/FO) and areas planted with emergent vegetation were designated EM. The boundaries of these areas are shown in figure 2 .

Table 4. Cumulative precipitation measured at Valley Forge National Historical Park for water years 2000-2006, Montgomery County, Pennsylvania.

\begin{tabular}{ccc}
\hline Water year & $\begin{array}{c}\text { Cumulative } \\
\text { precipitation } \\
\text { (inches) }^{\mathbf{2}}\end{array}$ & $\begin{array}{c}\text { Departure from } \\
\text { 30-year mean } \\
\text { (1971-2000) }^{\text {(inches) }}\end{array}$ \\
\hline 2001 & 35.35 & -6.70 \\
2002 & 30.50 & -11.55 \\
2003 & 71.66 & 29.61 \\
2004 & 59.75 & 17.70 \\
2005 & 40.10 & -1.95 \\
2006 & 54.31 & 12.26 \\
\hline
\end{tabular}

${ }^{1}$ Water year is the 12-month period October 1 through September 30. The water year is designated by the calendar year in which it ends and which includes 9 of the 12 months.

${ }^{2}$ Data from Northeast Regional Climate Center (2007a).

330-year mean of 42.05 inches was measured at Philadelphia International Airport (Northeast Regional Climate Center, 2007a).

disturbed site conditions that initially existed after construction. Some planted and non-planted woody species also were present at this time, including Sal. nigra and Cornus spp. Sal. nigra favored areas that had consistent hydric-soil indicators (table 3 ) in the vicinity of plots $0302,0303,0402$, and 0502. Cornus spp. (dogwood species) generally was established in and around plots 0103 and 0202, which seemed to have infrequently saturated soils (fig. 5) and less consistent hydric-soil indicators (table 3). By fall of 2002, Ec. crusgalli was not growing in any of the sample plots, and other herbaceous [Ag. stolonifera and Festuca rubra (red fescue)] and woody (Cornus spp. and Sal. nigra) species became more common (table 2). Sal. nigra contributed 30-percent cover by fall 2002 and continued to increase through 2006. By fall 2006, 15 to $25 \mathrm{ft}$ tall Sal. nigra trees and 4 to $8 \mathrm{ft}$ Cornus spp. shrubs dominated the tree/shrub stratum [ 48 and 13 percent of the areal cover, respectively (table 2)], and much of the understory was shaded. This left shade-intolerant species at a competitive disadvantage. For example, $Q$. bicolor and $V i$. dentatum contributed only 2- and 3-percent areal cover in fall 2006, and Ac. saccharinum, which provided 1-percent cover in fall 2002 and fall 2003, was not observed during the remainder of the study. By 2006, some non-planted species including Populus deltoides (cottonwood) and Betula sp. began to establish around the margins of the SS/FO part and in the enhanced natural wetland. These trees were growing outside of established sampling plots.

Ag. stolonifera and Ty. latifolia were dominant components of the herbaceous understory in the SS/FO part by 2006 (21- and 17-percent areal cover, respectively). Ag. stolonifera favored the shaded areas and Ty. latifolia grew near the margins of the SS/ FO part where more sunlight was available. Other notable herbaceous species that were observed at the end of monitoring in 2006 include Polygonum persicaria (lady's thumb; 11-percent areal cover), Sc. cyperinus (wool grass; 7-percent areal cover) and Urtica dioica (stinging nettle; 5-percent areal cover). Nasturtium officinale (Watercress), which contributed 10-percent areal cover and was a dominant species in fall 2004, was not observed in fall 2005 and contributed only 3-percent areal cover in fall 2006.

Various invasive species were observed throughout the study period but did not seem to be affecting the ability of native species to establish and dominate the site. Dipsacus sylvestris (teasel), a tall biennial native to Europe, Humulus japonicus (japanese hops), a creeping vine native to Asia, and Ec. crusgalli, a grass native to Eurasia, were the most prevalent invasive species (table 2). In fall 2006, H. japonicus 
contributed 2-percent areal cover, but other invasives listed above were not observed. It is assumed that work efforts completed by PennDOT during 3 of the 7 years $(03,04$, and 06) to manually remove $H$. japonicus played a role in controlling the spread of this species.

\section{Stream Channel}

In spring 2001, PennDOT installed rock deflectors within Valley Creek to mitigate selected locations exhibiting active streambank erosion. The response of the channel following installation of the structures is a direct function of structure characteristics, channel morphology, and hydrologic conditions to which the modified stream channel was subjected. From June 2001 through September 2006, two reaches of the channel (see upstream and downstream reaches in figure 4) were monitored annually (see table 1 for dates of monitoring) to document changes at least partially attributable to this mitigation effort.

\section{Hydrologic Conditions}

The streamflow-gaging station at Valley Creek at Pennsylvania Turnpike Bridge near Valley Forge, Pa. (fig. 1), has been in operation since October 1982. This gaging station is useful for characterizing the hydrologic conditions between annual monitoring assessments and for placing the monitoring data within the context of a period of record in excess of 20 years.

Data used for the hydrologic characterization were collected during the 2001-06 monitoring period (Durlin and Schaffstall, 2001-2005; Durlin and others, 2006; U.S. Geological Survey, 2007). The annual mean streamflow for the period of record ending water year 2006 was $33.5 \mathrm{ft}^{3} / \mathrm{s}$. Annual mean streamflow during the period the modified stream reach was monitored ranged from $15.2 \mathrm{ft}^{3} / \mathrm{s}$ in the 2002 water year to $53.0 \mathrm{ft}^{3} / \mathrm{s}$ in the 2004 water year. This is a range of about 55 percent lower to 58 percent higher than the annual mean streamflow for the period of record. Maximum annual instantaneous streamflows, during the monitoring period, ranged from 576 (June 6, 2002) to 2,730 $\mathrm{ft}^{3} / \mathrm{s}$ (September 28, 2004). During the monitoring period, 19 separate storms had streamflows with recurrence intervals of 1.5 years or greater (probabilities of exceedance of 67 percent or less). Streamflows with recurrence intervals of 1-2 years (1.5 years on average) commonly are considered to be the most effective or dominant channel-forming flows (Dunne and Leopold, 1978). The highest streamflow for the period of record at the Valley Creek streamflow-gaging station is $6,280 \mathrm{ft}^{3} / \mathrm{s}$ on September 16, 1999.

\footnotetext{
${ }^{4}$ Water year is the 12-month period October 1 through September 30. The water year is designated by the calendar year in which it ends and which includes 9 of the 12 months.
}

\section{Changes to the Channel}

The slope of a stream channel is one of several key factors in determining sediment transport. An increasing channel slope and associated increasing stream velocity may increase the particle size the channel can transport during a given flow and result in a coarsening of bed material; conversely, a decreasing slope may reduce transport and cause a decrease in particle size.

Elevations surveyed throughout fixed distances upstream and downstream from each cross section shown in figure 2 were used to compute water surface and streambed slopes at the upstream and downstream reaches of the modified stream channel (tables 5 and 6). The extent of each reach was intended to isolate the portion of the channel in the immediate vicinity of a rock deflector and to document the resulting channel response.

Water-surface and streambed slopes at the two reaches (shown in figure 2) remained relatively stable during the monitoring period, ranging from 0.01 to $0.02 \mathrm{ft} / \mathrm{ft}$ in the upstream reach (table 5) and 0.01 to $0.04 \mathrm{ft} / \mathrm{ft}$ in the downstream reach (table 6) with no more than $\pm 0.01 \mathrm{ft} / \mathrm{ft}$ variation compared to the initial conditions established in June 2001. The minor slope fluctuations noted between annual surveys of the longitudinal profiles are not considered to be appreciable and, in many cases, are primarily the result of mathematical rounding in the slope computation. Changes in stationing, length of reach or riffle, or in the actual positions of distinct channel features are, in most cases, attributed to inconsistent placement of the measuring tape rather than changes to the reach profiles. Variations in the appearance of the upstream and downstream profiles, as displayed in figures 6 and 7, are evidence of slight deposition or erosion within the reaches and, in most instances, are considered more a function of transient material passing through the reaches than an actual lasting change. One possible exception is the apparent accumulation of material in the pool at the downstream reach in the vicinity of station 115 during the 2006 assessment. Continued monitoring over a range of hydrologic conditions would be necessary to determine if this was a change in the sediment transport of the reach or a temporary characteristic as displayed near station 70 in the 2002 profile. The overall consistency of the reach slopes is most likely because of the presence of bedrock at the streambed (visibly cropping out around stations 70-90 in the upstream reach) prohibiting downcutting of the channel and the presence of sufficient energy within the system to transport the material supplied to each reach.

Sequences of deeper pools with slow-flowing water and shallow riffles with higher-velocity flow provide physical habitat composed of a great diversity of bed forms, substrate materials, and local velocities capable of supporting biotic diversity (Gordon and others, 1992). Over the monitoring period, the extent of the riffle and pools composing each reach stayed relatively constant; the length of the riffle remained within 4 percent of the June 2001 length. 
Table 5. Longitudinal profile characteristics of the upstream reach of the modified stream channel, Tredyffrin Township, Chester County, Pennsylvania.

$[\mathrm{ft}$, feet]

\begin{tabular}{|c|c|c|c|c|c|c|c|c|c|c|c|}
\hline \multirow[b]{2}{*}{ Profile characteristics } & \multirow{2}{*}{$\begin{array}{l}\text { June } \\
2001\end{array}$} & \multirow{2}{*}{$\begin{array}{l}\text { Sept. } \\
2002\end{array}$} & \multirow[b]{2}{*}{$\begin{array}{l}\text { Sept. } \\
2003\end{array}$} & \multirow[b]{2}{*}{$\begin{array}{l}\text { Sept. } \\
2004\end{array}$} & \multirow[b]{2}{*}{$\begin{array}{l}\text { Sept. } \\
2005\end{array}$} & \multirow[b]{2}{*}{$\begin{array}{l}\text { Sept. } \\
2006\end{array}$} & \multicolumn{5}{|c|}{ Change, in percent } \\
\hline & & & & & & & $\begin{array}{c}2001- \\
2002\end{array}$ & $\begin{array}{c}2001- \\
2003\end{array}$ & $\begin{array}{c}2001- \\
2004\end{array}$ & $\begin{array}{c}2001- \\
2005\end{array}$ & $\begin{array}{c}2001- \\
2006\end{array}$ \\
\hline Reach length (ft) & 90.0 & 90.0 & 90.0 & 90.0 & 90.0 & 90.0 & 0 & 0 & 0 & 0 & 0 \\
\hline Reach bed slope (ft/ft) & .02 & .01 & .01 & .01 & .01 & .01 & -50 & -50 & -50 & -50 & -50 \\
\hline Riffle water-surface slope (ft/ft) & .01 & .02 & .01 & .01 & .01 & .01 & 100 & 0 & 0 & 0 & 0 \\
\hline Riffle length (ft) & 38.5 & 38.0 & 38.0 & 38.0 & 38.0 & 38.0 & -1 & -1 & -1 & -1 & -1 \\
\hline
\end{tabular}

Table 6. Longitudinal profile characteristics of the downstream reach of the modified stream channel, Tredyffrin Township, Chester County, Pennsylvania.

[ft, feet]

\begin{tabular}{|c|c|c|c|c|c|c|c|c|c|c|c|}
\hline \multirow[b]{2}{*}{ Profile characteristics } & \multirow{2}{*}{$\begin{array}{l}\text { June } \\
2001\end{array}$} & \multirow{2}{*}{$\begin{array}{l}\text { Sept. } \\
2002\end{array}$} & \multirow{2}{*}{$\begin{array}{l}\text { Sept. } \\
2003\end{array}$} & \multirow[b]{2}{*}{$\begin{array}{l}\text { Sept. } \\
2004\end{array}$} & \multirow{2}{*}{$\begin{array}{l}\text { Sept. } \\
2005\end{array}$} & \multirow{2}{*}{$\begin{array}{l}\text { Sept. } \\
2006\end{array}$} & \multicolumn{5}{|c|}{ Change, in percent } \\
\hline & & & & & & & $\begin{array}{c}2001- \\
2002\end{array}$ & $\begin{array}{c}2001- \\
2003\end{array}$ & $\begin{array}{c}2001- \\
2004\end{array}$ & $\begin{array}{c}2001- \\
2005\end{array}$ & $\begin{array}{c}2001- \\
2006\end{array}$ \\
\hline Reach length (ft) & 70.0 & 73.0 & 73.0 & 73.0 & 73.0 & 73.0 & 4 & 4 & 4 & 4 & 4 \\
\hline Reach bed slope (ft/ft) & .03 & .03 & .02 & .02 & .04 & .02 & 0 & -33 & -33 & 33 & -33 \\
\hline Riffle water-surface slope (ft/ft) & .01 & .01 & .01 & .01 & .01 & .01 & 0 & 0 & 0 & 0 & 0 \\
\hline Riffle length (ft) & 58.0 & 60.6 & 60.6 & 60.6 & 60.6 & 60.6 & 4 & 4 & 4 & 4 & 4 \\
\hline
\end{tabular}




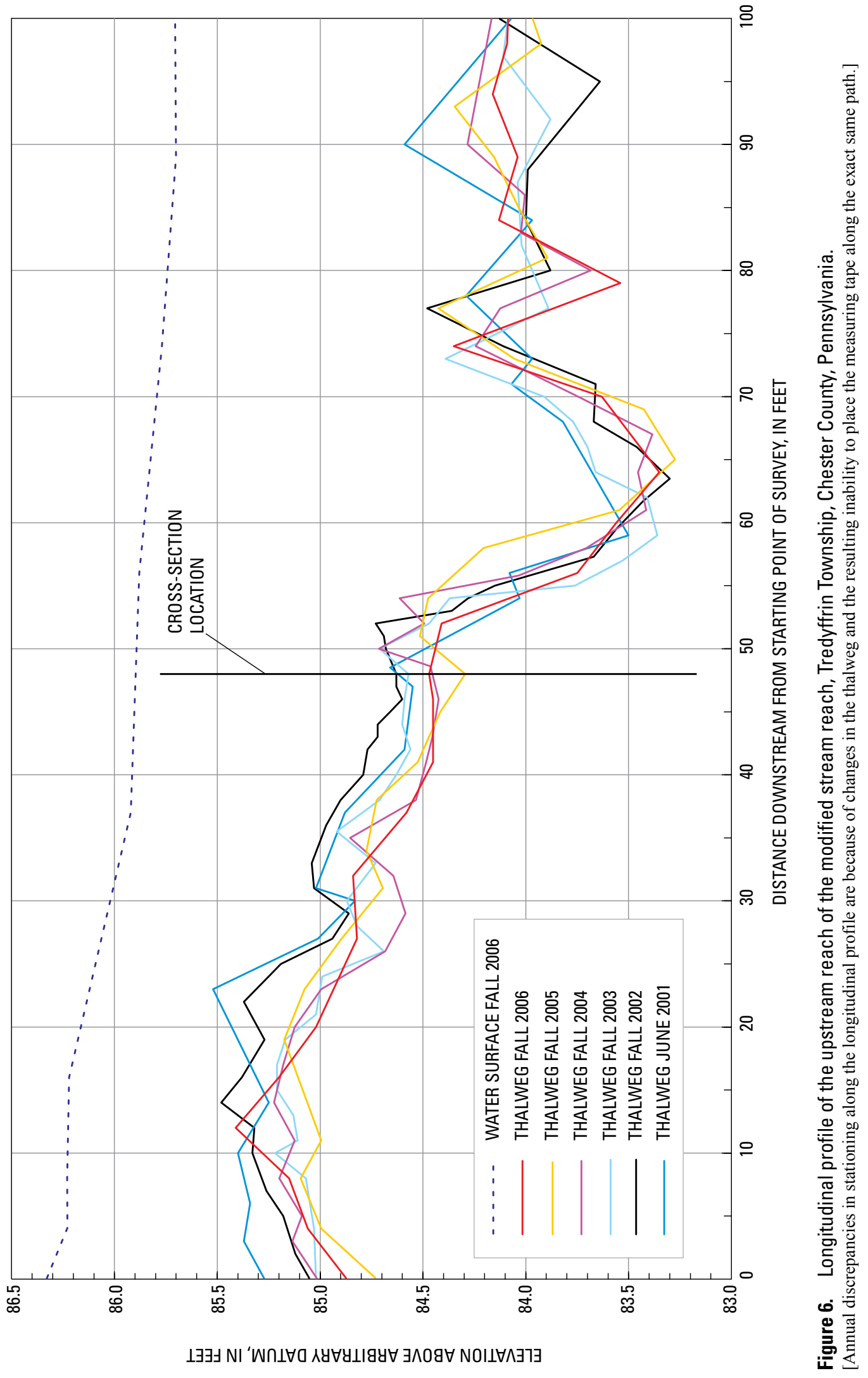




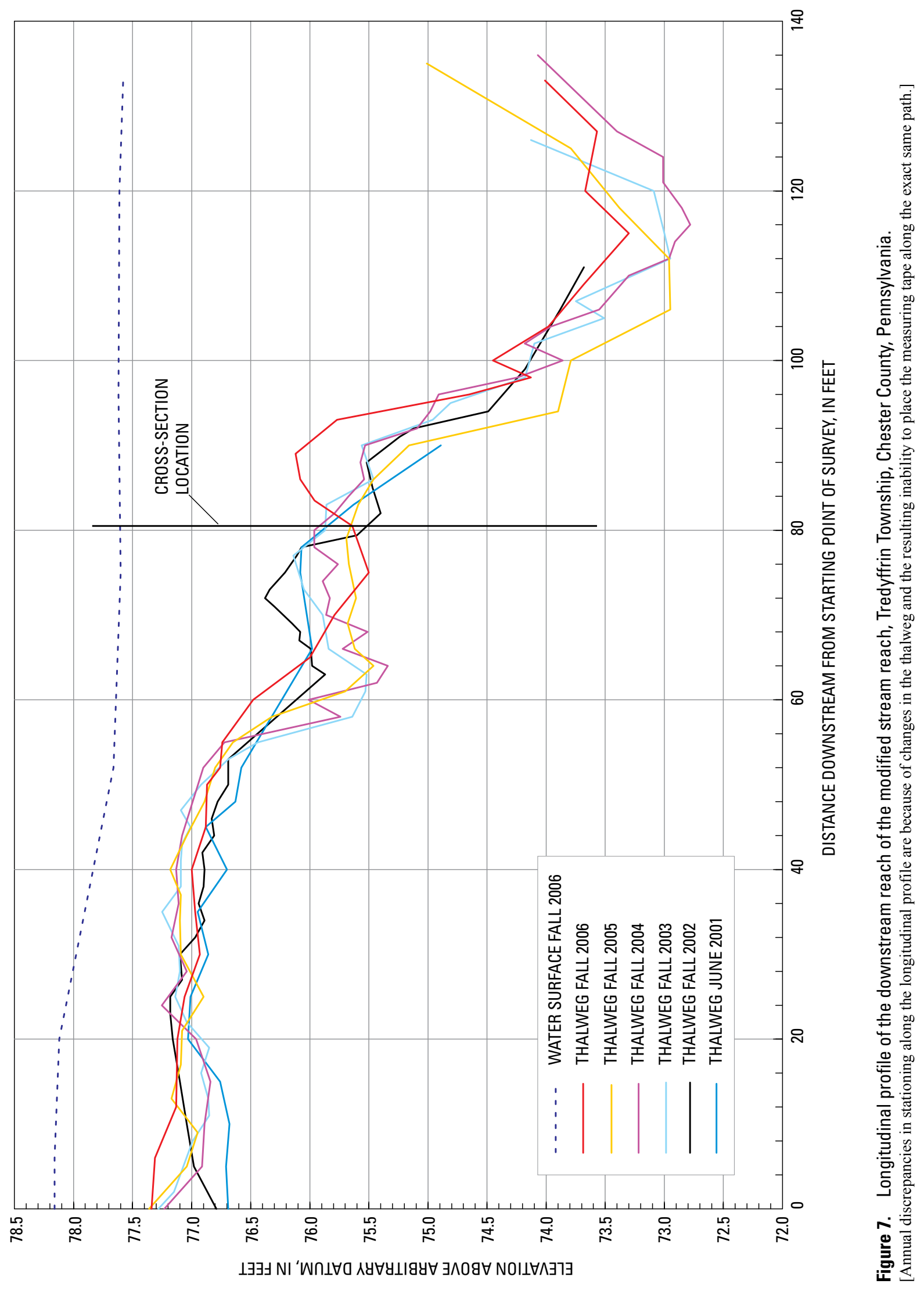


Changes in width, mean and maximum depth, and area of a cross section are indications of the degree to which a channel is adjusting. The stream channel will continue to adjust until it reaches dynamic equilibrium, a condition that exists when the stream channel is capable of conveying the streamflow and sediment load being supplied without excessive erosion or deposition that may lead to changes in channel morphology.

Since monitoring began in June 2001, the cross section in the upstream reach experienced changes in channel morphology in the 1-3 percent range; the one exception was maximum depth, which decreased by 6 to 9 percent over the monitoring period when compared to the June 2001 survey (table 7). Removing one 2001 isolated survey point in the active channel near station 48 from consideration results in an overall change of about 3 percent during the monitoring period, more in line with the other parameters. A notable feature in the 2001 and 2002 survey (fig. 8) is the inclusion of a tree on the left bank that was no longer present during subsequent surveys. Streambank erosion in the upstream reach, measured as a result of exposure of bank pins, was a maximum of $0.8 \mathrm{ft}$ over the monitoring period.

The cross section in the downstream reach experienced notable channel enlargement over the monitoring period as a result of erosion of the right streambank. Relatively stable over the first 3 years of monitoring, the 2005 assessment documented 9 percent increases in both cross-sectional area and mean cross-section depth due, in part, to erosion of the right bank (bank pins indicated an average of $0.86 \mathrm{ft}$ of bank erosion) as well as the cutting of a secondary channel on the left bank and slight bed erosion. Distance from the right streambank to the landward-most rock of the deflector (which is upstream from the surveyed cross section) was about $3 \mathrm{ft}$ in 2005 , thus decreasing the protection of the bank and quite pos- sibly exacerbating the erosion by directing accelerated flow into the "toe" of the bank. Over the following year, substantial bank retreat was evident; cross-sectional area increased by $33 \mathrm{ft}^{2}$ (13 percent) between 2005 and 2006 for a total increase of $54 \mathrm{ft}^{2}$ (23 percent) over the entire monitoring period. The monument on the right bank marking the extent of the surveyed cross section and both bank pins (used to quantify bank retreat) were destroyed as a result of $8.0 \mathrm{ft}$ of bank erosion that occurred between fall 2005 and fall 2006 (fig. 9). Cumulative bank erosion, as measured with bank pins and cross-section surveys, was greater than $10 \mathrm{ft}$ over the entire monitoring period. As a result of the erosion noted during the 2006 assessment, the distance between the right bank and the landwardmost rock in the deflector was about $14 \mathrm{ft}$, essentially leaving the rock deflectors in mid-stream where they provided no protection of the bank. As indicated by the change in channel morphology at the downstream reach it is apparent that the rock deflectors were ineffective at adequately protecting the bank from erosion.

The particle distribution of a stream is indicative of the sediment load being supplied to the system as well as the ability of the stream to transport it. The coarser the sediment, the more energy required to transport it. On the basis of the median particle-size category (D50), as determined during pebble counts for both cross sections throughout the monitoring period, Valley Creek can be characterized as a gravel-bed stream.

Particle distributions in the upstream reach, determined during the June 2001 assessment, tended to be notably coarser than in the subsequent four assessments (table 7 and fig. 10). Particle distributions in the upstream reach decreased throughout all distribution categories through the 2005 assessment when compared to the results of the June 2001 assessment. An

Table 7. Cross-section dimensions and bed-particle-size distribution in the upstream reach, Tredyffrin Township, Chester County, Pennsylvania.

$\left[\mathrm{D} 15,15^{\text {th }}\right.$ percentile bed-particle size; D35, $35^{\text {th }}$ percentile bed-particle size; D50, $50^{\text {th }}$ percentile bed-particle size; D84, $84^{\text {th }}$ percentile bed-particle size; D95, $95^{\text {th }}$ percentile bed-particle size; $<$, less than]

\begin{tabular}{|c|c|c|c|c|c|c|c|c|c|c|c|}
\hline \multirow[b]{2}{*}{ Profile characteristics } & \multirow{2}{*}{$\begin{array}{l}\text { June } \\
2001\end{array}$} & \multirow{2}{*}{$\begin{array}{l}\text { Sept. } \\
2002\end{array}$} & \multirow{2}{*}{$\begin{array}{l}\text { Sept. } \\
2003\end{array}$} & \multirow{2}{*}{$\begin{array}{l}\text { Sept. } \\
2004\end{array}$} & \multirow{2}{*}{$\begin{array}{l}\text { Sept. } \\
2005\end{array}$} & \multirow{2}{*}{$\begin{array}{l}\text { Sept. } \\
2006\end{array}$} & \multicolumn{5}{|c|}{ Change, in percent } \\
\hline & & & & & & & $\begin{array}{c}2001- \\
2002\end{array}$ & $\begin{array}{c}2001- \\
2003\end{array}$ & $\begin{array}{c}2001- \\
2004\end{array}$ & $\begin{array}{c}2001- \\
2005\end{array}$ & $\begin{array}{c}2001- \\
2006\end{array}$ \\
\hline Cross-section area, in square feet & 202 & 197 & 202 & 200 & 200 & 205 & -2 & 0 & -1 & -1 & 1 \\
\hline Baseline width, in feet & 74.0 & 74.2 & 74.0 & 74.2 & 74.2 & 74.2 & $<1$ & 0 & $<1$ & $<1$ & $<1$ \\
\hline Mean cross-section depth, in feet & 2.74 & 2.66 & 2.72 & 2.70 & 2.69 & 2.77 & -3 & -1 & -1 & -2 & 1 \\
\hline \multicolumn{12}{|l|}{ Pebble count, in millimeters: } \\
\hline D15 & 3.0 & 1.1 & 2.2 & 2.6 & 1.3 & 3.7 & -63 & -27 & -13 & -57 & 23 \\
\hline D35 & 22.1 & 8.8 & 12.2 & 7.1 & 8.7 & 52 & -60 & -45 & -68 & -61 & 135 \\
\hline D50 & 56.3 & 21.4 & 33.7 & 19.6 & 26.9 & 86 & -62 & -40 & -65 & -52 & 53 \\
\hline D84 & 199 & 173 & 128 & 184 & 148 & 187 & -13 & -36 & -8 & -26 & -6 \\
\hline
\end{tabular}




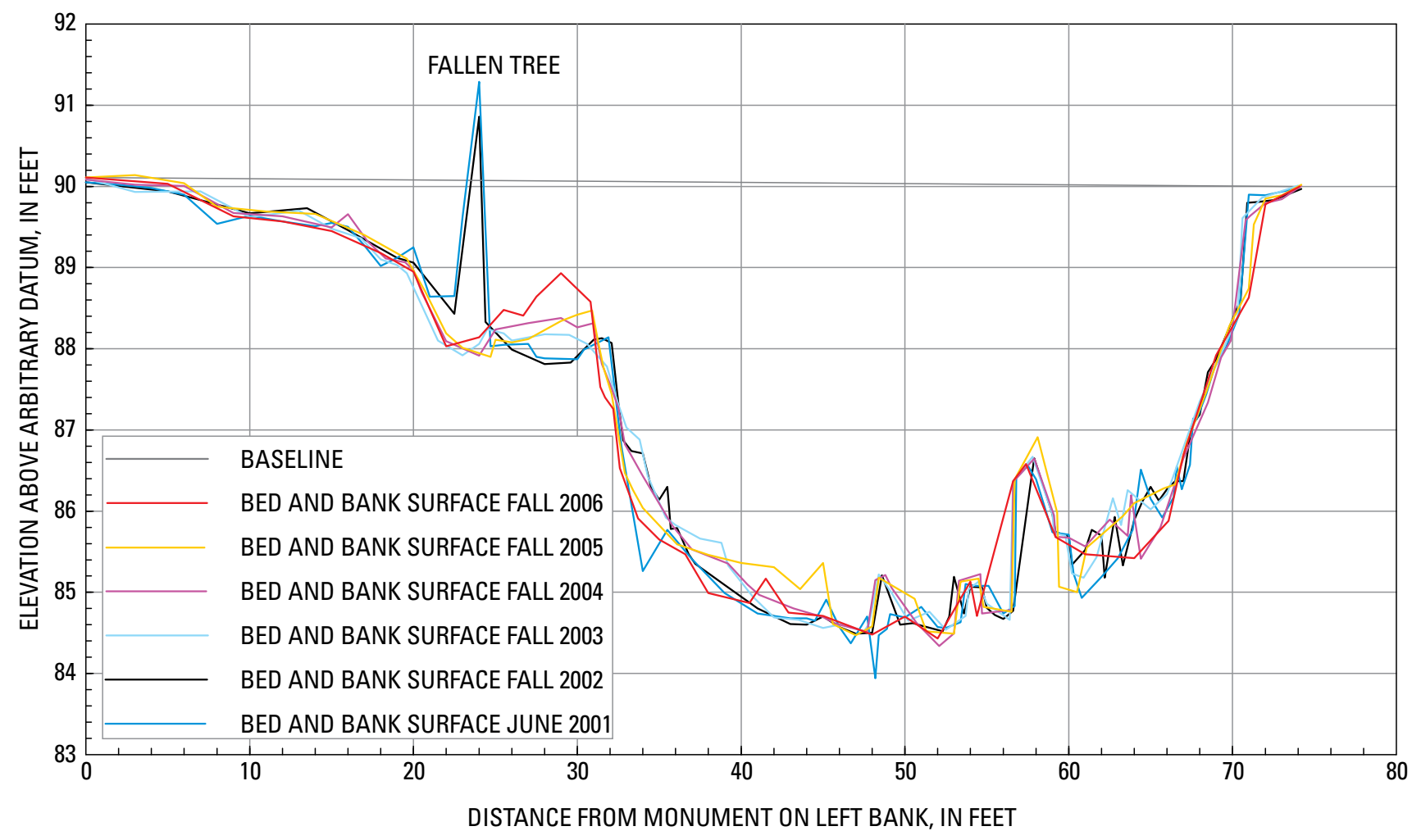

Figure 8. Surveys of the upstream cross section of the modified stream reach, Tredyffrin Township, Chester County, Pennsylvania. 


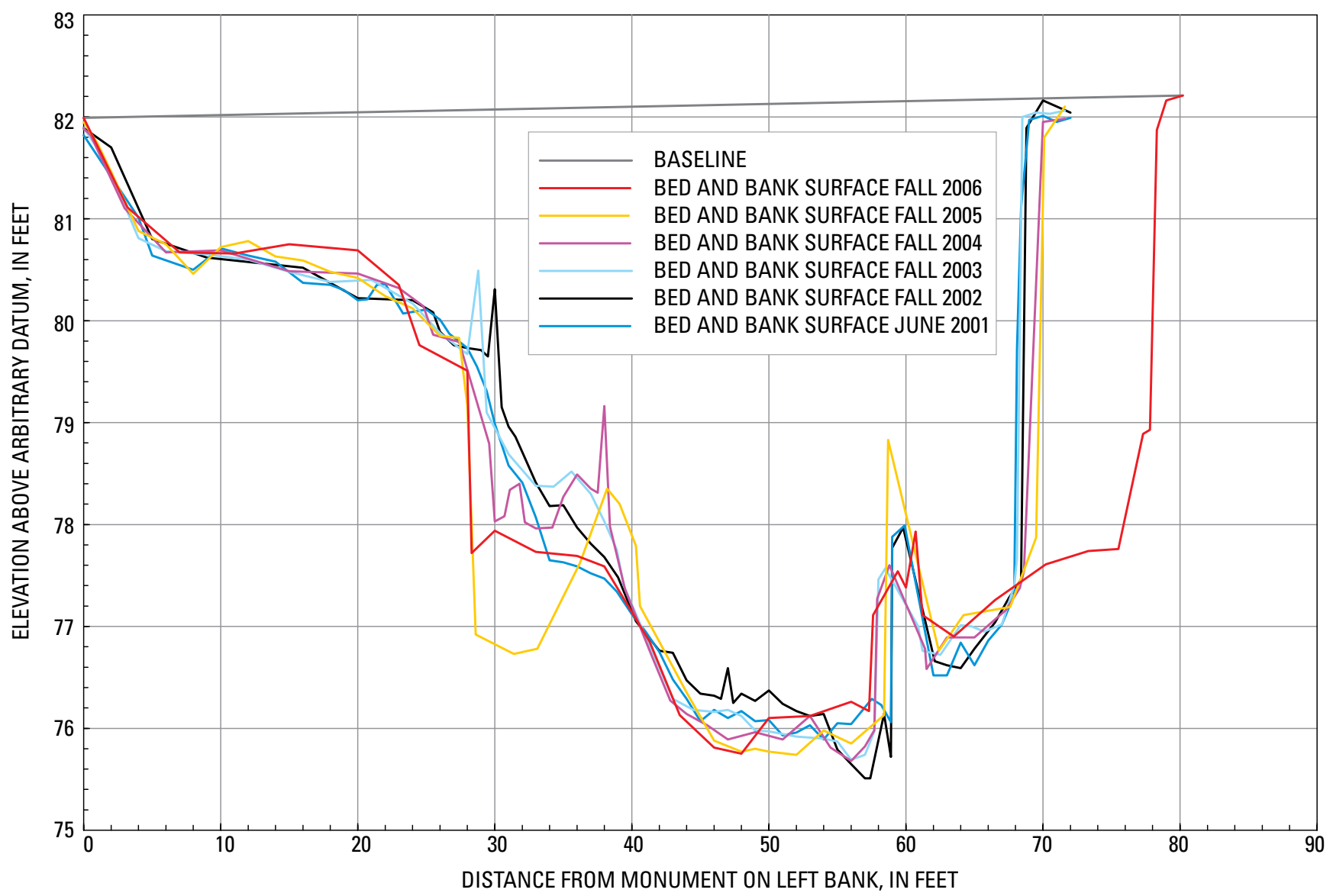

Figure 9. Surveys of the downstream cross section of the modified stream reach, Tredyffrin Township, Chester County, Pennsylvania. 


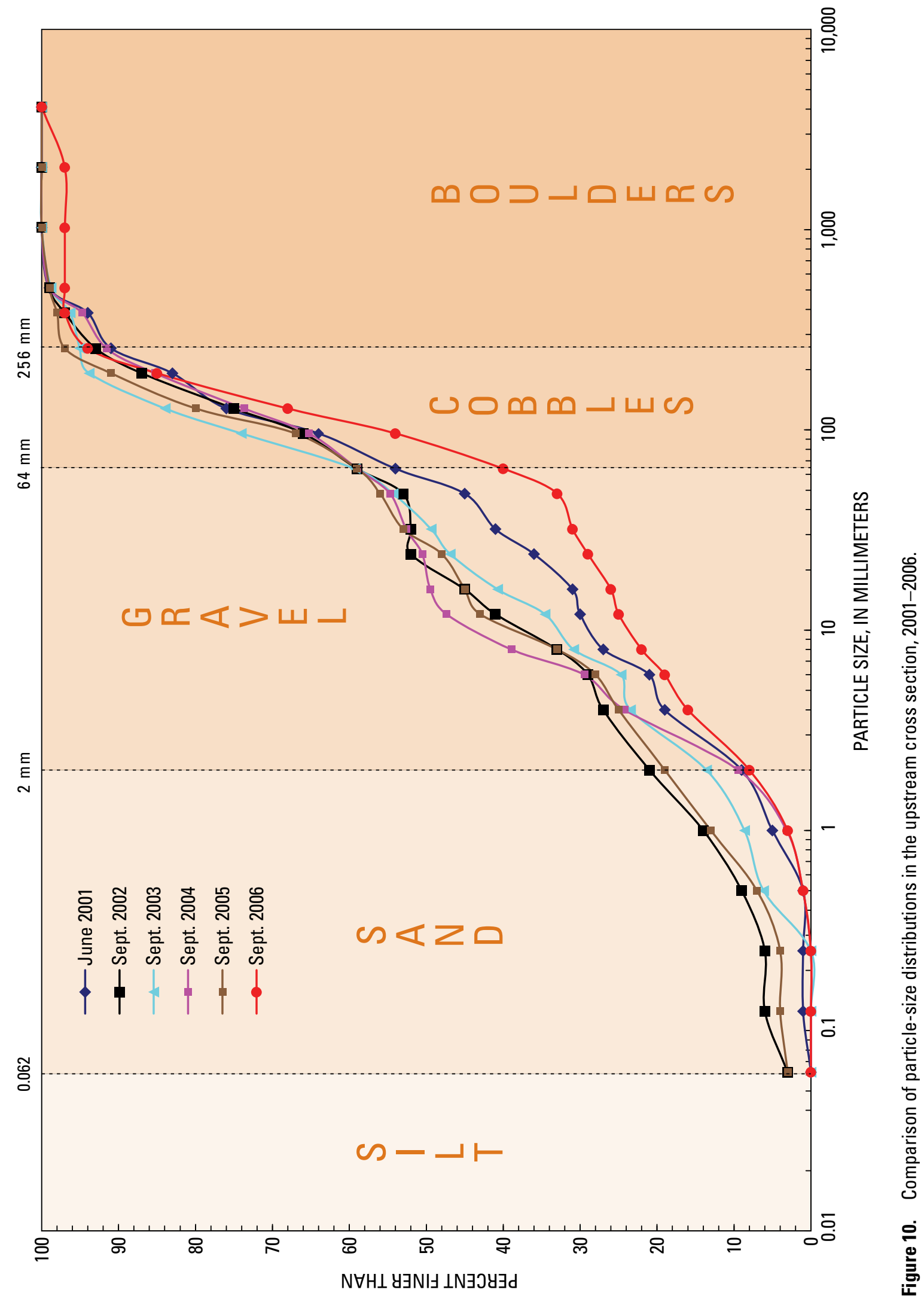


average decrease of about 50 percent was noted in the D15 to D50 distribution categories, tending to be composed of coarse gravels. The average particle size for the D50 category, among all assessments, was $41 \mathrm{~mm}$. The D84 and D95 categories decreased in size by an average of 24 percent and were characterized by cobbles and boulders. The pebble count during the 2006 assessment indicated a reversal of the previous trend toward smaller particles in the D15 to D50 categories, resulting, on average, in a 70-percent increase in particle sizes, still primarily gravels but noticeably coarser. The coarsening of the material in these size categories is most likely indicative of the load being carried by preceding storms and the continued capability of this reach to transport a majority of the material being provided. The D84 and D95 categories continued to be smaller than during the June 2001 assessment.

Particle distributions in the cross section in the downstream reach generally decreased in size in all categories and for all assessments with only two exceptions (table 8 and fig. 11). Similar to the upstream reach, an average decrease of about 50 percent was noted in the D15 to D50 distribution categories; most particles were characterized as coarse gravels. The average particle size for the D50 category, among all assessments, was $22 \mathrm{~mm}$. The D84 and D95 categories decreased in size over the monitoring period by an average of 22 percent and were characterized by cobbles. Unlike the upstream reach, particle distributions in all size distributions, except the D95, decreased in size in 2006. The continued presence of finer material within the cross section, when compared to the June 2001 assessment, suggests a decrease in the sediment transport of this reach. This is commonly the case when a channel is actively widening, resulting in decreasing depths of streamflow which, in turn, decreases the ability of the stream to transport sediment.

\section{Riparian Buffer}

Because of the replacement plantings in 2001 and 2002, the most reliable time frame for interpretation of trends in the number and condition of riparian plantings is 2003-2006. The most prevalent planted tree species that was surviving in 2003 was Pl. occidentalis (63 individuals), followed by $\mathrm{Ca}$. caroliniana (35), Q. palustris (33), Al. serrulata (30), Ac. rubrum (26), Ac. saccharinum (17), and Sal. nigra (10) (fig. 12). The most prevalent shrubs in 2003 were Cornus spp. (dogwood species; 98 individuals), followed by $\mathrm{Sa}$. discolor (51), Ph. opulifolius and $V$. dentatum (28), Cl. alnifolia (27), and Sp. virginiana (4). Drought conditions in the fall of 2001 and throughout 2002 (Northeast Regional Climate Center, 2007b) may have been the primary cause of stress or death in newly planted trees and shrubs and could have had prolonged effects lasting throughout the study.

A large percentage of trees and shrubs remained stressed in 2003 including $Q$. palustris (65 percent), Al. serrulata (36 percent), Ac. rubrum (34 percent), and Sa. discolor (57 percent) (fig. 13) despite higher than average precipitation in the summer months of 2003 (Northeast Regional Climate Center, 2007a; table 4). Trees and shrubs that appreciably declined in number between 2003 and 2006 [including Sal. nigra, Alnus serrulata, Ac. saccharinum, Sa. discolor, and Cl. alnifolia (fig. 12)] generally exhibited more stress in 2003 (fig. 13) compared to their counterparts that remained nearly constant or increased in number throughout the study (fig. 12). Note that year-to-year decreases in the percentage of stressed individuals over time does not necessarily indicate improvement in the overall well being of the original plantings. For example, the percentage of stressed plants in a given year may

Table 8. Cross-section dimensions and bed-particle-size distribution in the downstream reach, Tredyffrin Township, Chester County, Pennsylvania.

$\left[\mathrm{D} 15,15^{\text {th }}\right.$ percentile bed-particle size; D35, $35^{\text {th }}$ percentile bed-particle size; D50, $50^{\text {th }}$ percentile bed-particle size; D84, $84^{\text {th }}$ percentile bed-particle size; D95, $95^{\text {th }}$ percentile bed-particle size; NC, not computed because percentage of smallest particles in 2002 assessment exceeded 15 percent; <, less than]

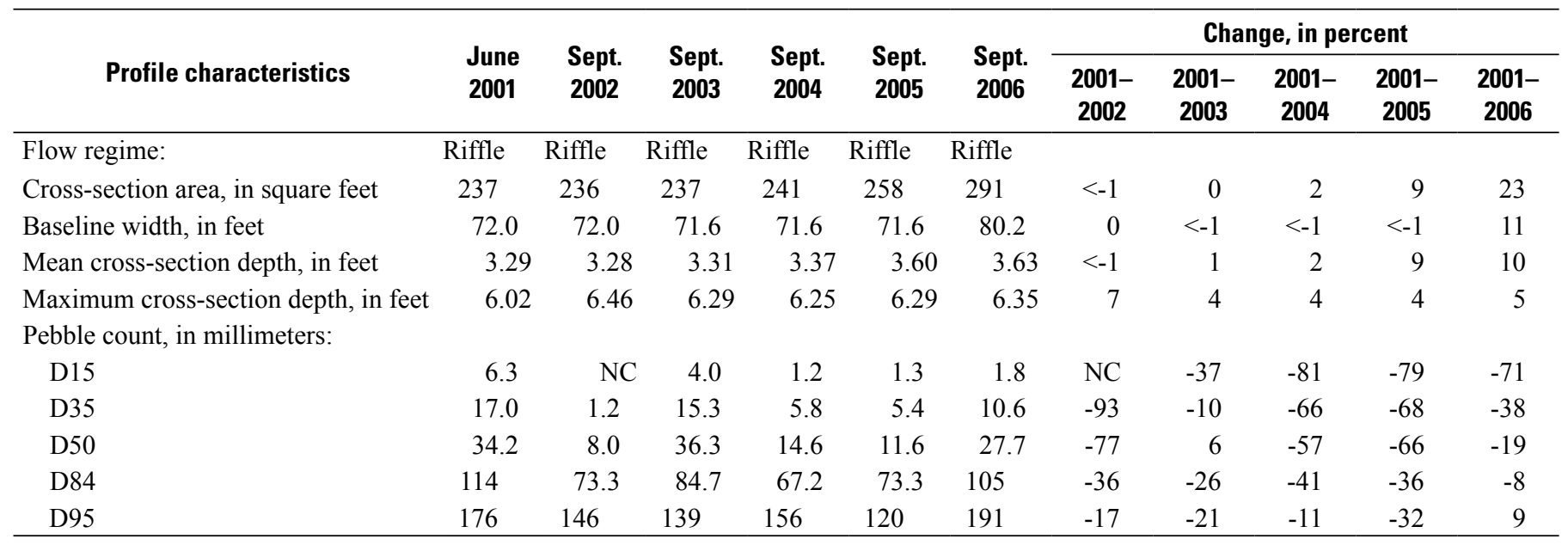




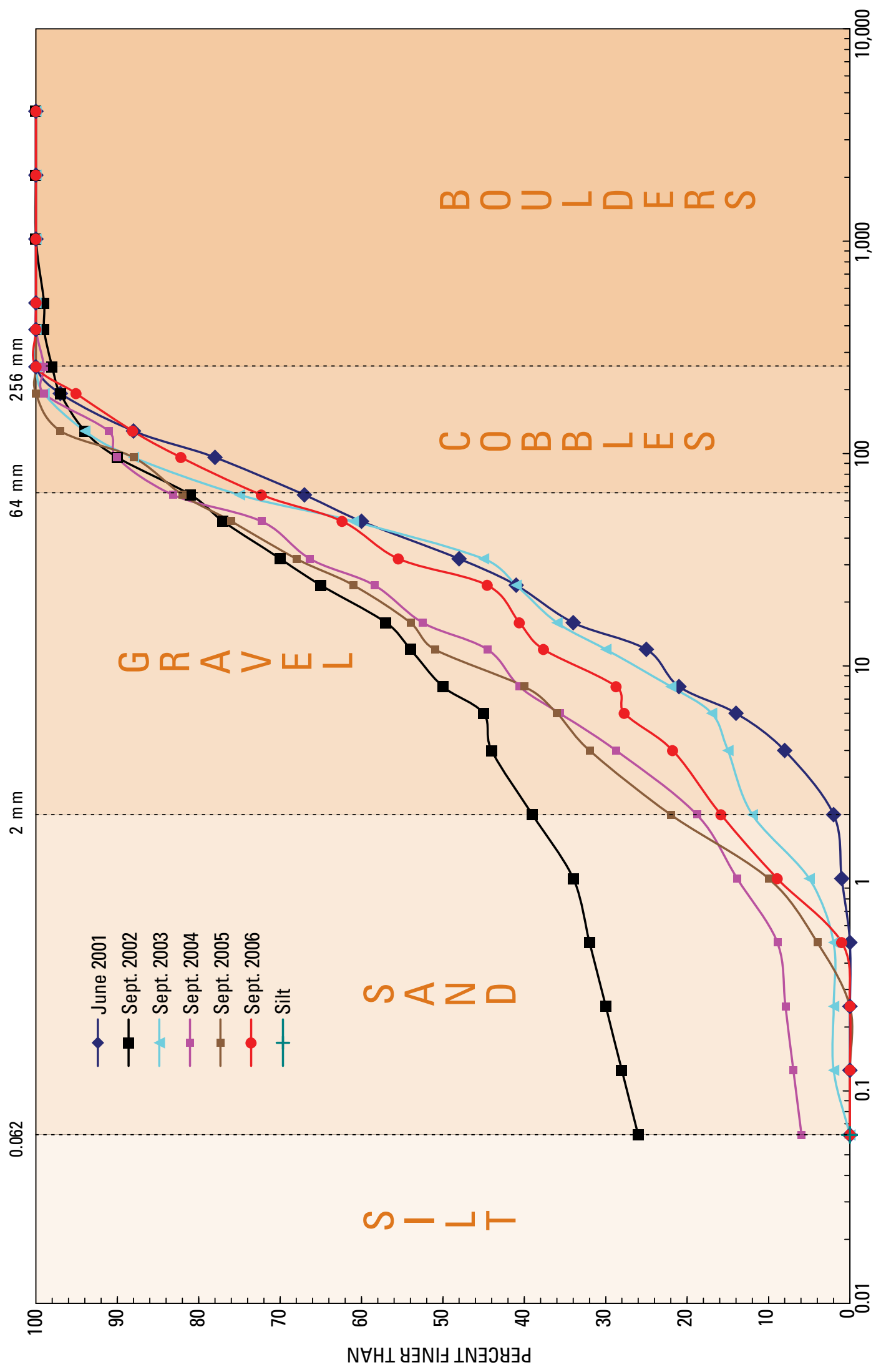

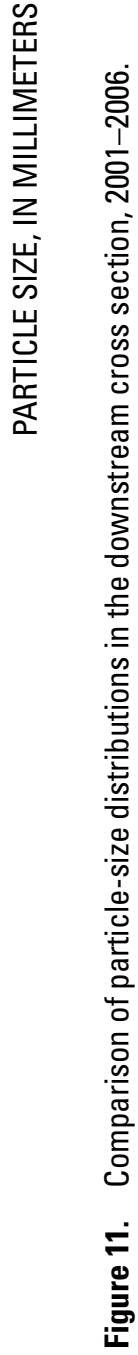



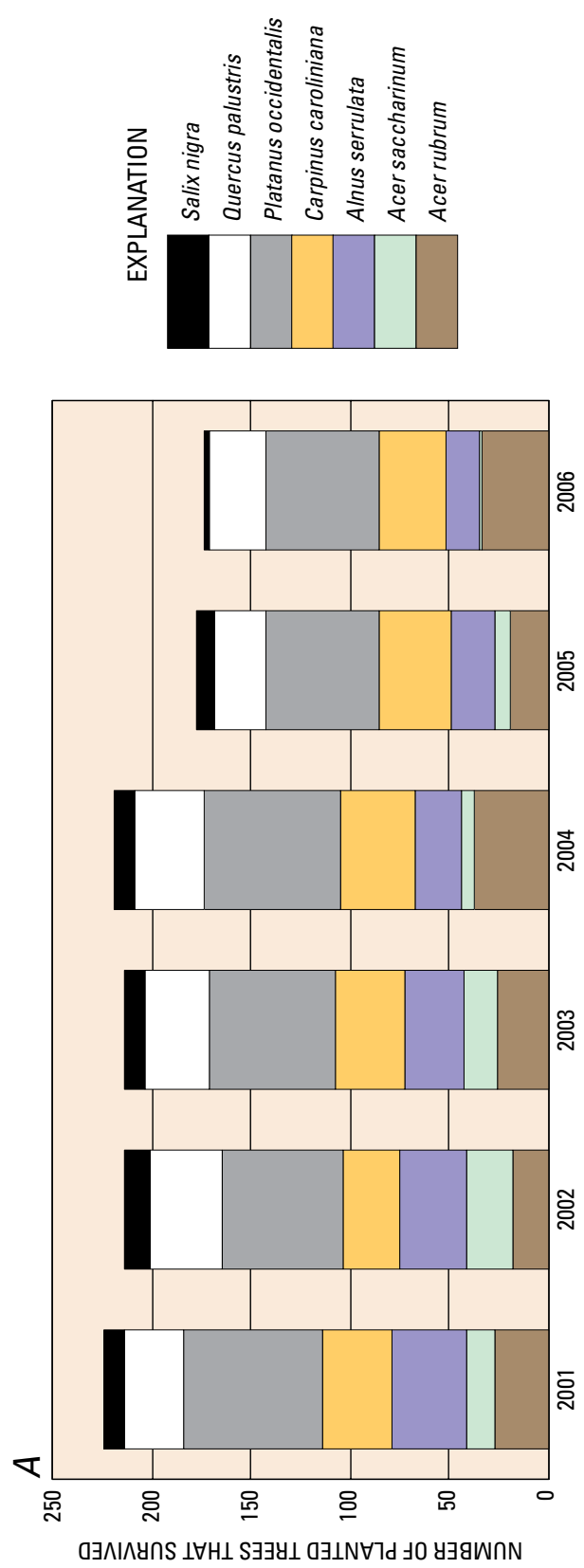
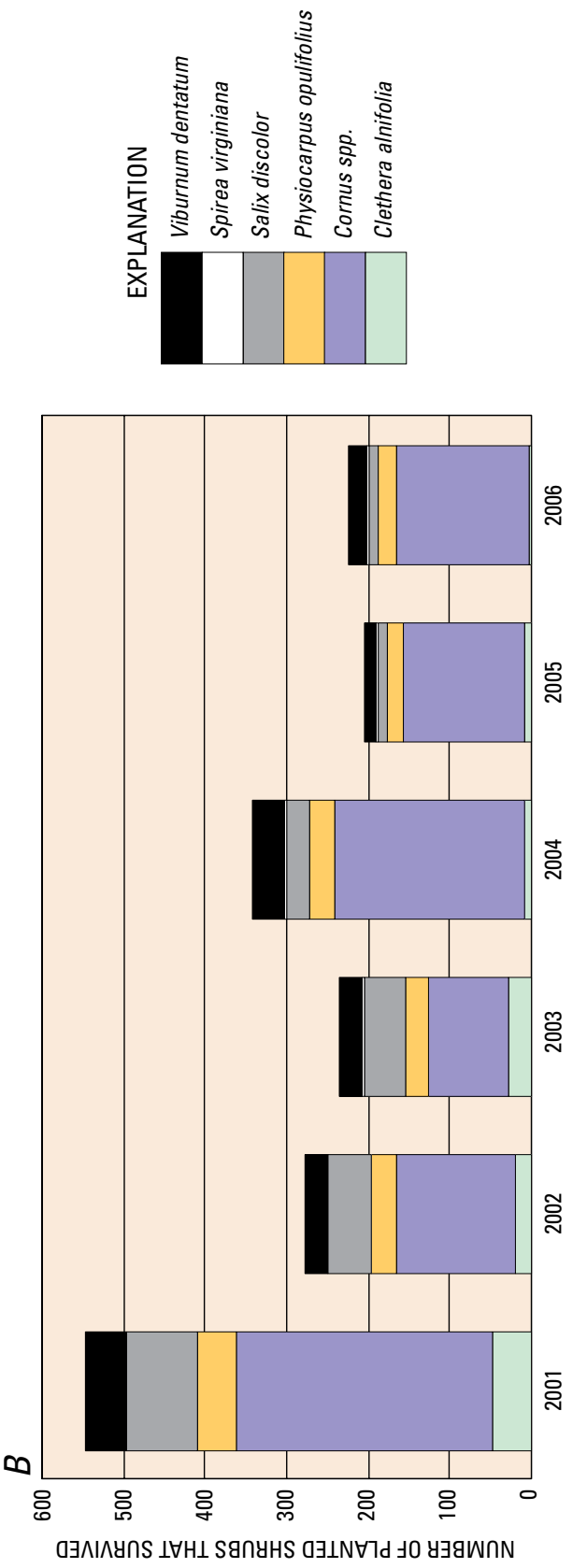

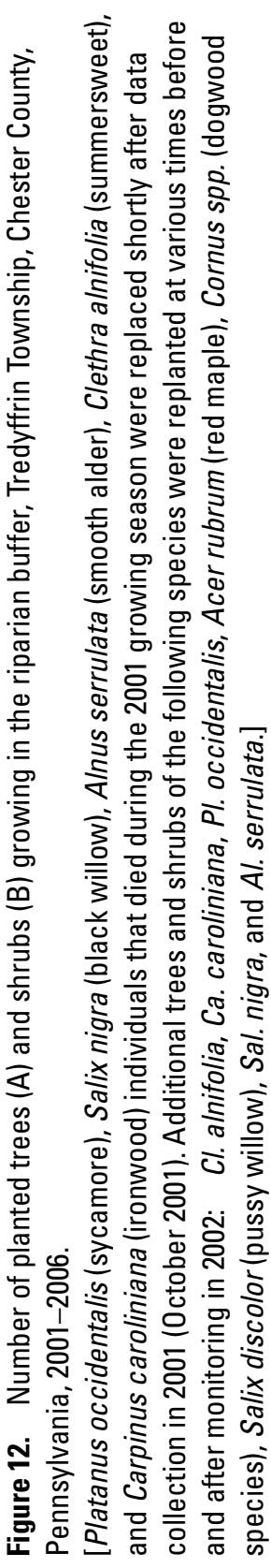



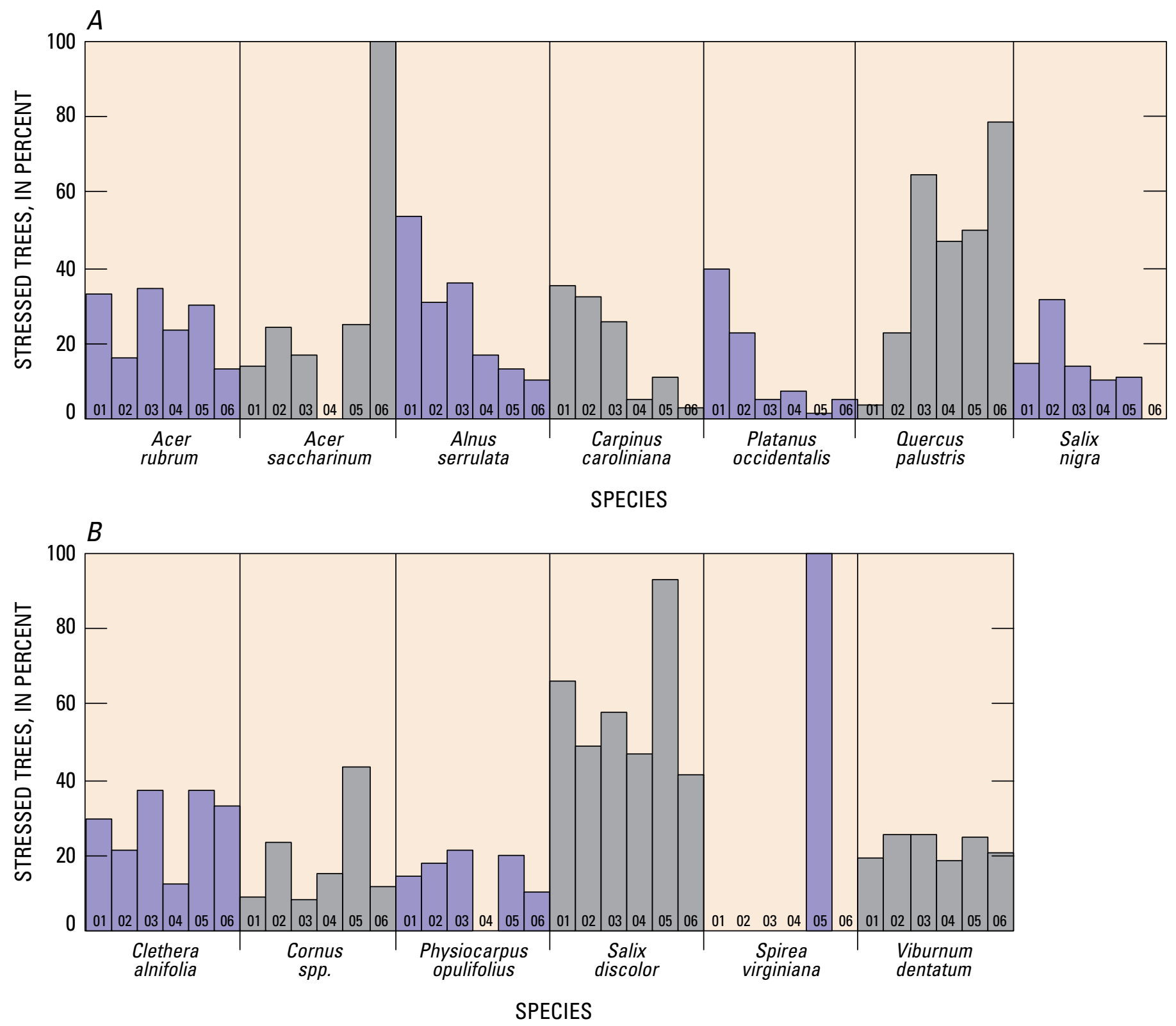

Figure 13. Percentage of planted species of trees $(A)$ and shrubs $(B)$ in the riparian buffer that were stressed, Tredyffrin Township, Chester County, Pennsylvania, 2001-2006.

[Year-to-year decreases in the percentage of stressed individuals over time may not indicate improvement in the overall well-being of a given species. For example, the percentage of stressed plants in a given year may decrease because the weakest plants died the year before, leaving only the healthiest, least-stresssed plants.] 
decrease because the weakest plants died the year before, leaving only the healthiest, least-stressed plants.

In the year preceding fall 2006 monitoring, infrequent but debris-laden overbank flows breached some of the exclosure fences, allowing deer and other herbivores uninhibited access. Data collected in fall 2006 indicate herbivores preferred to browse planted species rather than non-planted vegetation (table 9). As a result, 23 percent of planted species were browsed and 17 percent were stressed in 2006 (table 9). By contrast, none of the non-planted species were browsed, and only 7 percent exhibited signs of stress (table 9). Browsing was most common among the planted shrub species; greater than 25 percent of Cornus spp., Cl. alnifolia, $V$. dentatum, and $\mathrm{Sa}$. discolor plants were browsed. This is presumably because the shrubs were smaller (4-8 ft tall) and more accessible by deer; trees in most groups were 10-20 ft tall in 2006 except for $\mathrm{Pl}$. occidentalis, which ranged from 15 to $30 \mathrm{ft}$ tall.

Dissimilarities in the incidence of browsing and stress among these species contributed to a decrease in the number of planted trees and shrubs and an increase in the number of surviving non-planted plants between 2001 and 2006. Despite replacement of dead individuals in 2001 and 2002, planted trees decreased from 214 in 2001 to 171 in 2006 (fig. 12A) and shrubs decreased from 546 in 2001 to 225 in 2006 (fig. 12B). By contrast, the cumulative number of the two most prevalent non-planted species [Acer negundo (box elder) and Gymnocladus dioicus (Kentucky coffee tree)] more than doubled over the same time period (from 110 to 244 plants) (fig. 14). These two species are native to Pennsylvania (Rhoads and Block, 2000) and were most prevalent in group numbers 1 (Ac. negundo and Gy. dioicus), 18, 28, and 34 (Ac. negundo), at the end of the study. The density of planted species at the end of the study was 382 plants per acre compared to 329 plants per acre for non-planted species (table 9). Although decreases in the number of planted individuals were appreciable, the remaining plants grew substantially in most groups, often achieving canopy closure (see photographs in figures 5-2 through 5-11 in appendix 5).

Data collected in 2006 indicate non-native plant species could be the greatest future threat to woody vegetation growing in planted areas of the riparian buffer. Lonicera spp. (honeysuckle species), including two bush species native to Japan, were found in groups 5, 6, and 7 in 2006. Humulus japonicus, a creeping herbaceous vine native to Asia is ubiquitous; it was growing in groups 1, 2, 6, 7, 21, 22, 23, 25, 29, 31, and 34 .

Polygonum perfoliatum, a climbing vine from Asia commonly called mile-a-minute-weed, was found in plots 1, 7, 18, 20, 22,30 , and 33 . These species have a tendency to displace, smother, or otherwise out-compete native species if not kept in check.

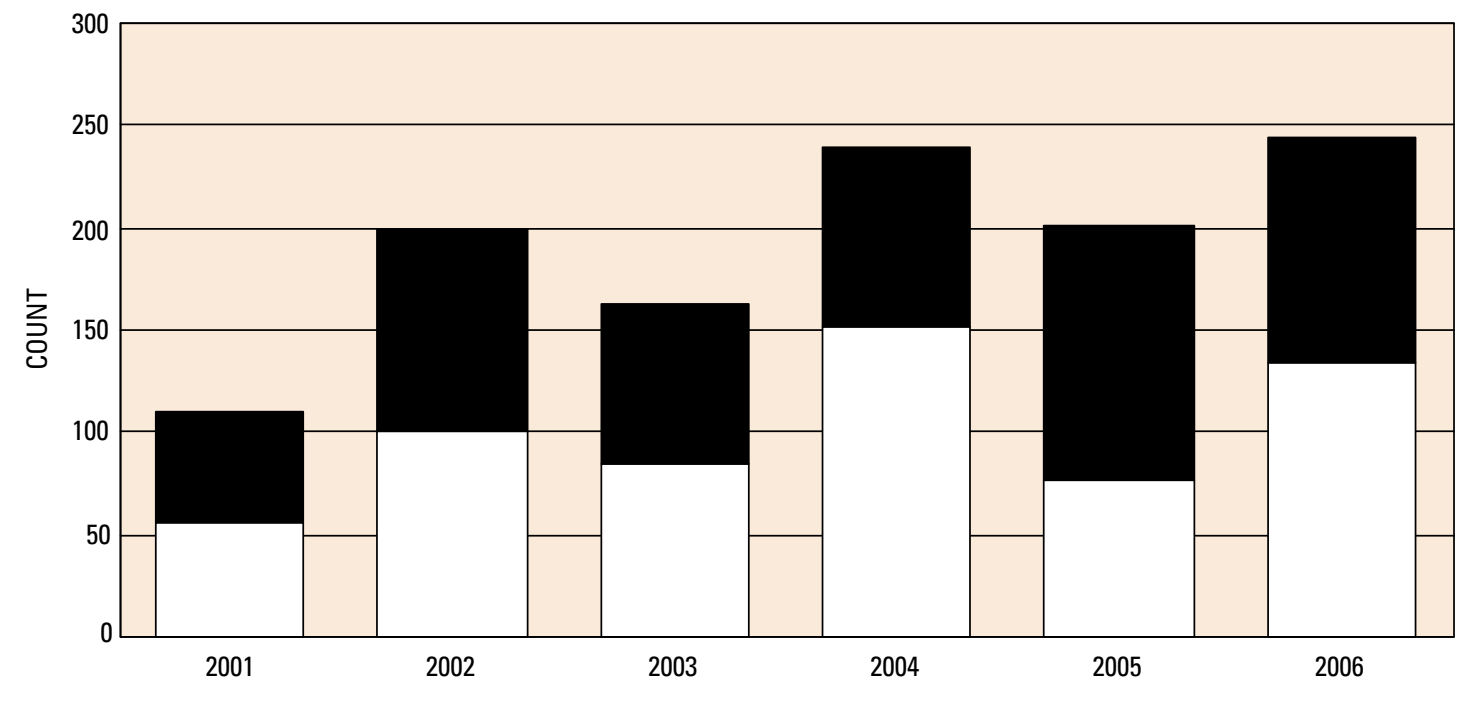

EXPLANATION

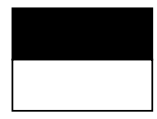

Gymnocladus dioicus

Acer negundo

Figure 14. Number of Acer negundo (box elder) and Gymnocladus dioicus (Kentucky coffee tree) plants growing in the riparian buffer, Tredyffrim Township, Chester County, Pa., 2001-2006. 
Table 9. Woody trees and shrubs growing in the riparian buffer, fall 2006.

[\%, percent; shading indicates the species is a tree, no shading indicates the species is a shrub]

\begin{tabular}{|c|c|c|c|c|c|c|c|}
\hline \multicolumn{2}{|c|}{ Species } & \multirow{2}{*}{ Alive } & \multicolumn{2}{|c|}{ Stressed $^{1}$} & \multicolumn{2}{|c|}{ Browsed $^{2}$} & \multirow{2}{*}{$\begin{array}{c}\text { Density } \\
\text { (plants per } \\
{\text { acre })^{3}}^{\text {a }}\end{array}$} \\
\hline Latin Name & Common Name & & $\%$ & Count & $\%$ & Count & \\
\hline Acer negundo & box elder & 134 & 13 & 18 & 0 & 0 & 126 \\
\hline Acer rubrum $^{4}$ & red maple & 34 & 15 & 5 & 0 & 0 & 32 \\
\hline Acer saccharinum $^{4}$ & silver maple & 1 & 100 & 1 & 0 & 0 & 1 \\
\hline Alnus serrulata ${ }^{4}$ & smooth alder & 17 & 12 & 2 & 0 & 0 & 16 \\
\hline Carpinus caroliniana ${ }^{4}$ & ironwood & 33 & 3 & 1 & 0 & 0 & 31 \\
\hline Clethra alnifolia ${ }^{4}$ & summersweet & 3 & 33 & 1 & 33 & 1 & 3 \\
\hline Cornus spp. ${ }^{4}$ & dogwood species & 169 & 11 & 19 & 47 & 82 & 159 \\
\hline Fraxinus pennsylvanica & green ash & 32 & 9 & 3 & 0 & 0 & 30 \\
\hline Gleditsia triacanthos & honey locust & 16 & 0 & 0 & 0 & 0 & 15 \\
\hline Gymnocladus dioicus & kentucky coffee-tree & 110 & 0 & 0 & 0 & 0 & 104 \\
\hline Hibiscus syriacus & rose of sharon & 1 & 0 & 0 & 0 & 0 & 1 \\
\hline Juglans nigra & Black Walnut & 12 & 0 & 0 & 0 & 0 & 11 \\
\hline Ligustrum vulgare & european privet & 2 & 0 & 0 & 0 & 0 & 2 \\
\hline Lindera benzoin & spicebush & 9 & 0 & 0 & 0 & 0 & 8 \\
\hline Liriodendron tulipifera & tulip tree & 1 & 100 & 1 & 0 & 0 & 1 \\
\hline Lonicera sp. & honeysuckle & 25 & 0 & 0 & 0 & 0 & 24 \\
\hline Maclura pomifera & osage-orange & 1 & 0 & 0 & 0 & 0 & 1 \\
\hline Physocarpus opulifolius ${ }^{4}$ & ninebark & 22 & 5 & 1 & 0 & 0 & 21 \\
\hline Platanus occidentalis ${ }^{4}$ & sycamore & 57 & 5 & 3 & 0 & 0 & 54 \\
\hline Prunus serotina & black cherry & 2 & 0 & 0 & 0 & 0 & 2 \\
\hline Quercus palustris ${ }^{4}$ & pin oak & 29 & 90 & 26 & 0 & 0 & 27 \\
\hline Quercus rubra & red oak & 2 & 50 & 1 & 0 & 0 & 2 \\
\hline Quercus sp. & oak species & 1 & 0 & 0 & 0 & 0 & 1 \\
\hline Salix discolor ${ }^{4}$ & pussy willow & 11 & 45 & 5 & 27 & 3 & 10 \\
\hline Salix nigra ${ }^{4}$ & black willow & 3 & 0 & 0 & 0 & 0 & 3 \\
\hline Spirea virginiana ${ }^{4}$ & Virginia spirea & 2 & 0 & 0 & 0 & 0 & 2 \\
\hline Ulmus americana & American elm & 1 & 0 & 0 & 0 & 0 & 1 \\
\hline Viburnum dentatum ${ }^{4}$ & arrowood & 24 & 21 & 5 & 33 & 8 & 23 \\
\hline Totals for planted species & & 405 & 17 & 69 & 23 & 94 & 382 \\
\hline Totals for non-planted spe & & 349 & 7 & 23 & 0 & 0 & 329 \\
\hline Totals for all species & & 754 & 12 & 92 & 12 & 94 & 711 \\
\hline
\end{tabular}

${ }^{1}$ Plants that have no foliage, discolored foliage, or malformed fruiting structures.

${ }^{2}$ Plants damaged from feeding by deer or other herbivores.

${ }^{3}$ Total area of 1.06 acres was planted.

${ }^{4}$ Species was planted. 


\section{Summary}

Maintenance and improvement of transportation infrastructure commonly necessitates alteration of existing stream channels and (or) naturally occurring wetlands. Compensatory mitigation for wetland and stream encroachments is usually required by Federal and State regulatory agencies and commonly includes modification or construction of wetlands, stream channels, and associated riparian buffers. From 1998 through 2003, the Pennsylvania Department of Transportation (PennDOT) made roadway improvements to $5.5 \mathrm{mi}$ of U.S. Highway 202 in Chester and Montgomery Counties, Pa. To compensate for authorized disturbance of naturally occurring wetlands and streams, PennDOT constructed 0.42 acre of emergent wetland and 0.94 acre of scrub-shrub/forested wetland and modified sections of a 1,600-foot reach of Valley Creek with woody riparian plantings and streambank-stabilization structures (including rock deflectors). The constructed wetland is in the headwaters of an unnamed tributary to Valley Creek and is about 1 straight-line mile south of the modified stream reach, which is within Valley Forge National Historical Park (Valley Forge Park). In accordance with project permits and additional guidance issued by the U.S. Army Corps of Engineers to PennDOT and Tredyffrin Township, the U.S. Geological Survey (USGS), in cooperation with PennDOT, collected data from 2000 through 2006 to quantify changes in 1) the vegetation, soils, and extent of emergent and scrubshrub/forested parts of the constructed wetland, 2) the profile, dimension, and substrate in the vicinity of stabilization structures placed at two locations within the modified stream reach, and 3) the woody vegetation within the planted riparian buffer. The data for this investigation were collected using an approach adapted from previous investigations so that findings may be more easily transferred among projects with similar objectives.

Areal cover by planted and non-planted vegetation growing within the emergent and scrub-shrub/forested parts of the constructed wetland exceeded 85 percent throughout this investigation, a criterion set forth in special condition $25 \mathrm{c}$ in the U.S. Army Corps of Engineers project permit. Areal cover in the emergent part of the constructed wetland ranged from 101 to 139 percent (fall 2001 and fall 2000, respectively) and was 135 percent in fall 2006, the final year of data collection. Frequent and long-lasting soil saturation favored obligatewetland species like Typha latifolia (broadleaf cattail) and Scirpus validus (great bulrush), which maintained dominance in the emergent wetland throughout the study. Sc. validus was the only planted herbaceous species that provided appreciable cover because it was best suited to effectively compete with Ty. latifolia. Although $S c$. validus initially covered the greatest area within the emergent wetland (43 percent in fall 2000), Ty. latifolia steadily increased throughout the study (from 30 percent in 2000 to 78 percent in 2006) and eventually displaced $S c$. validus, which contributed only 20 percent cover in 2005 and 2006. Other species such as Impatiens capensis (jewelweed) and Agrostis stolonifera (spreading bentgrass) were sparingly present throughout the study.

Areal cover in the scrub-shrub/forested part of the constructed wetland ranged from 97 percent in 2001 to 146 percent in 2000 and was 139 percent in 2006. Echinocloa crusgalli (barnyard grass), an annual invasive from Eurasia, initially established the newly disturbed soils in 2000 (areal cover was 56 percent), but by 2002, E. crusgalli was not growing in any of the sample plots, and other species including Ag. stolonifera, Festuca rubra (red fescue), Cornus spp. (dogwood species), and Sal. nigra were becoming more common. Sal. nigra contributed 30 percent cover by fall 2003. Rapid colonization of this species resulted in annual increases in cover through 2006 when 15 to $25 \mathrm{ft}$ tall Sal. nigra trees dominated the tree/shrub stratum (48 percent of the areal cover). The next most common woody plant in 2006 was Cornus spp., which contributed 13-percent cover. Ag. stolonifera and Ty. latifolia (21- and 17-percent areal cover, respectively) were dominant herbaceous components of the mostly shaded understory. Ag. stolonifera favored the well-shaded areas, and Ty. latifolia grew near the margins of the scrub-shrub/forested wetland where somewhat more sunlight was available. Other notable herbaceous species that were observed at the end of monitoring in 2006 included Polygonum persicaria (lady's thumb; 11-percent areal cover), Sc. cyperinus (wool grass; 7-percent areal cover), and Urtica dioica (stinging nettle; 5 -percent areal cover).

Longitudinal profiles surveyed near rock deflectors in two short (100-ft) reaches within the modified stream reach maintained a constant slope throughout the monitoring period, most likely because of the presence of bedrock control. The two surveyed reaches are within the modified stream reach and are separated by a distance of about $300 \mathrm{ft}$. The cross-section geometry in the upstream reach was virtually unchanged during the monitoring period. The cross-section geometry in the downstream reach experienced little change during the first 3 years of monitoring. During the 2005 assessment, notable channel erosion was measured, and the 2006 assessment documented substantially more, totaling a 23 -percent increase in cross-sectional area when compared to the initial assessment. Streambank erosion resulted in over $10 \mathrm{ft}$ of bank migration over the monitoring period, leaving the rock deflectors mid-stream where they provide no protection of the bank. As indicated by the change in channel morphology at the downstream reach it is apparent that the rock deflectors were ineffective at adequately protecting the bank from erosion. Particle distributions in both reaches, in general, became more fine over most of the monitoring period with the exception of the 2006 assessment, which showed coarsening in the $15^{\text {th }}$ and $50^{\text {th }}$-percentile size categories at the upstream reach. There was no evidence of deposition associated with the coarsening of the upstream reach in 2006, indicating transport capability was maintained or increased. The trend toward a finer particle distribution in the downstream reach suggests a decrease in sediment transport commonly associated with channel widening. 
In the riparian buffer adjacent to the modified stream reach, the most reliable time frame for interpretation of trends in the number and well being of riparian plantings is 2003-2006. The most prevalent tree species in 2003 was Platanus occidentalis (63 individuals), followed by Carpinus caroliniana (ironwood; 35 plants), Quercus palustris (pin oak; 33), Alnus serrulata (smooth alder; 30), Acer rubrum (red maple; 26), Acer saccharinum (silver maple; 17), and Sal. nigra (10). The most prevalent shrubs in 2003 were Cornus spp. (dogwood species; 98 individuals), followed by Salix discolor (pussy willow; 51), Physocarpus opulifolius (ninebark) and Viburnum dentatum (arrowood) (28 plants each), Clethra alnifolia (summersweet; 27), and Spirea virginiana (Virginia spirea; 4). A large percentage of trees and shrubs were stressed in 2003 after surviving two previous years of extensive drought. The most-stressed species in 2003 included $Q$. palustris (65 percent), Al. serrulata (36 percent), Ac. rubrum (34 percent), and Sa. discolor (57 percent). Trees and shrubs that appreciably declined in number between 2003 and 2006 (including Sal. nigra, Al. serrulata, Ag. saccharinum, $\mathrm{Sa}$. discolor, and $\mathrm{Cl}$. alnifolia) generally exhibited more stress in 2003 compared to their counterparts that remained nearly constant or increased in number throughout the study.

In the year preceding the fall 2006 monitoring, infrequent but debris-laden overbank flows breached some of the exclosure fences, allowing deer and other herbivores uninhibited access. Browsing that ensued was most common among the planted shrub species; greater than 25 percent of Cornus spp., Cl. alnifolia, $V$. dentatum, and Sa. discolor plants were browsed. Dissimilarities in the incidence of browsing and stress among these species contributed to a decrease in the number of planted trees and shrubs and an increase in the number of non-planted plants between 2001 and 2006. Despite replacement of dead individuals in 2001 and 2002, planted trees decreased from 214 in 2001 to 171 in 2006 and shrubs decreased from 546 in 2001 to 225 in 2006. By contrast, the two most prevalent non-planted native species [Acer negundo (box elder) and Gymnocladus dioicus (Kentucky coffee tree)] more than doubled in number over the same time period (from 110 to 244). The density of planted and non-planted trees and shrubs was 711 plants per acre. Determination of compliance with permit condition 29 , which establishes density requirements for planted and appropriate non-planted species within the riparian buffer, will be evaluated by the U.S. Army Corps of Engineers.

\section{References Cited}

Chaplin, J.J., White, K.E., and Loper, C.A., 2006, Physical and vegetative characteristics of a relocated stream reach, constructed wetland, and riparian buffer, Upper Saucon Township, Lehigh County, Pennsylvania, 2000-04: U.S. Geological Survey Scientific Investigations Report 20065042, 65 p.
Dunne, T., and Leopold, L.B., 1978, Water in environmental planning: San Francisco, Calif, W.H. Freeman, 818 p.

Durlin, R.R., and Schaffstall, W.P., 2001, Water resources data, Pennsylvania, water year 2000, volume 1, Delaware River Basin: U.S. Geological Survey Water-Data Report PA-00-1, 652 p.

Durlin, R.R., and Schaffstall, W.P., 2002, Water resources data, Pennsylvania, water year 2001, volume 1, Delaware River Basin: U.S. Geological Survey Water-Data Report PA-01-1, 529 p.

Durlin, R.R., and Schaffstall, W.P., 2003, Water resources data, Pennsylvania, water year 2002, volume 1, Delaware River Basin: U.S. Geological Survey Water-Data Report PA-02-1, 527p.

Durlin, R.R., and Schaffstall, W.P., 2004, Water resources data for Pennsylvania, water year 2003, volume 1, Delaware River Basin: U.S. Geological Survey Water-Data Report PA-03-1, 637 p.

Durlin, R.R., and Schaffstall, W.P., 2005, Water resources data for Pennsylvania, water year 2004, volume 1, Delaware River Basin: U.S. Geological Survey Water-Data Report PA-04-1, $651 \mathrm{p}$.

Durlin, R.R., Schaffstall, W.P., and Beaver, M.R., 2006, Water resources data for Pennsylvania, water year 2005, volume 1, Delaware River Basin: U.S. Geological Survey WaterData Report PA-05-1, 575 p.

Fitzpatrick, F.A., Waite, I.R., D’Arconte, P.J., Meador, M.R., Maupin, M.A., and Gurtz, M.E., 1998, Revised methods for characterizing stream habitat in the National Water-Quality Assessment Program: U.S. Geological Survey WaterResources Investigation Report 98-4052, 67 p.

Gordon, N.D., McMahon, T.A., and Finlayson, B.L., 1992, Stream hydrology, and introduction for ecologist: Chichester, England, John Wiley and Sons, 526 p.

Kunkle, M.W., 1963, Soil Survey of Chester and Delaware Counties, PA: U.S. Department of Agriculture, Soil Conservation Service, $124 \mathrm{p}$.

Munsell Color, 2000, Munsell Soil Color Charts: New Windsor, N.Y., Gretag Macbeth, variously paged.

Natural Resources Conservation Service, 2008, Web soil survey [online]: Soil map for Chester County, Pennsylvania (PA029), accessed March 5, 2008, at http://websoilsurvey.nrcs.usda.gov/app/WebSoilSurvey.aspx

Northeast Regional Climate Center, 2007a, The CLIMOD System: Cornell University, accessed January 11, 2007, at http://climod.nrcc.cornell.edu/. 
Northeast Regional Climate Center, 2007b, Pennsylvania drought periods: Cornell University, accessed January 11, 2007, at http://www.nrcc.cornell.edu/drought/ PA_drought_periods.html

Palone, R.S., and Todd, A.H., 1997, Chesapeake Bay riparian handbook: A guide to establishing and maintaining riparian forest buffers, revised in 1998, U.S. Department of Agriculture report NA-TP-0297, variously paged.

Pennsylvania Department of Conservation and Natural Resources, 2000, Limestone and dolomite distribution in Pennsylvania (4th ed.) [online]: Bureau of Topographic and Geologic Survey, map 15, accessed March 5, 2008, at http://www.dcnr.state.pa.us/topogeo/maps/map15.pdf

Price, C., Nakagaki, N., Hitt, K., and Clawges, R., 2003, Mining GIRAS - Improving on a national treasure of land use data: ESRI International User Conference 2003 Proceedings, accessed January 23, 2008, at http://gis.esri.com/ library/userconf/proc03/p0904.pdf

Reed, P.B., Jr., 1988, National list of plant species that occur in wetlands -northeast region 1 (amended 1993): Fort Collins, Colo., U.S. Fish and Wildlife Service, National Ecology Research Center. Biological Report 88 (26.1), 113 p.

Rhoads, A.F., and Block, T.A., 2000, The plants of Pennsylvania: Philadelphia, Pa., University of Pennsylvania Press, $1061 \mathrm{p}$.

Rosgen, D., 1996, Applied river morphology: Minneapolis, Minn., Printed Media Companies, 352 p.

Sevon, W.D., comp., 2000, Physiographic provinces of Pennsylvania (4th ed.) [online]: Bureau of Topographic and Geologic Survey map 13, accessed March 5, 2008, at http://www.dcnr.state.pa.us/topogeo/maps/map13.pdf

Tiner, R.W., 1999, Wetland indicators-A guide to wetland identification, delineation, classification, and mapping: Boca Raton, Fla., Lewis Publishers, 392 p.

URS Greiner Woodward Clyde, 1999a, Valley Creek stream enhancement plan for Valley Forge National Historical Park, Valley Forge, Pa: King of Prussia, Pa., 10 p.

URS Greiner Woodward Clyde, 1999b, Details and plant schedules wilson tract wetland mitigation plan for route 202, section 400 roadway improvements: King of Prussia, Pa., 5 p.

U.S. Army Corps of Engineers Environmental Laboratory, 1987, Corps of Engineers wetlands delineation manual: Vicksburg, Miss., U.S. Army Corps of Engineers Waterways Experiment Station, Technical Report Y-87-1, 100 p. plus appendixes, accessed July 21, 2005, at http://www.saj.usace.army.mil/permit/ documents/87manual.pdf
U.S. Geological Survey, 2007, USGS annual hydrologic data report for Pennsylvania: U.S. Geological Survey, accessed January 11, 2007, at http://web10capp.er.usgs.gov/imf/sites/ adr06/pdfs/01473169.2006.pdf

Wolman, M.G., 1954, A method of sampling coarse riverbed material: Transactions of the American Geophysical Union, v. 35, p. 951-956. 

Appendix 1. Photographs of the Constructed Wetland, Tredyffrin Township, Chester County, Pennsylvania 


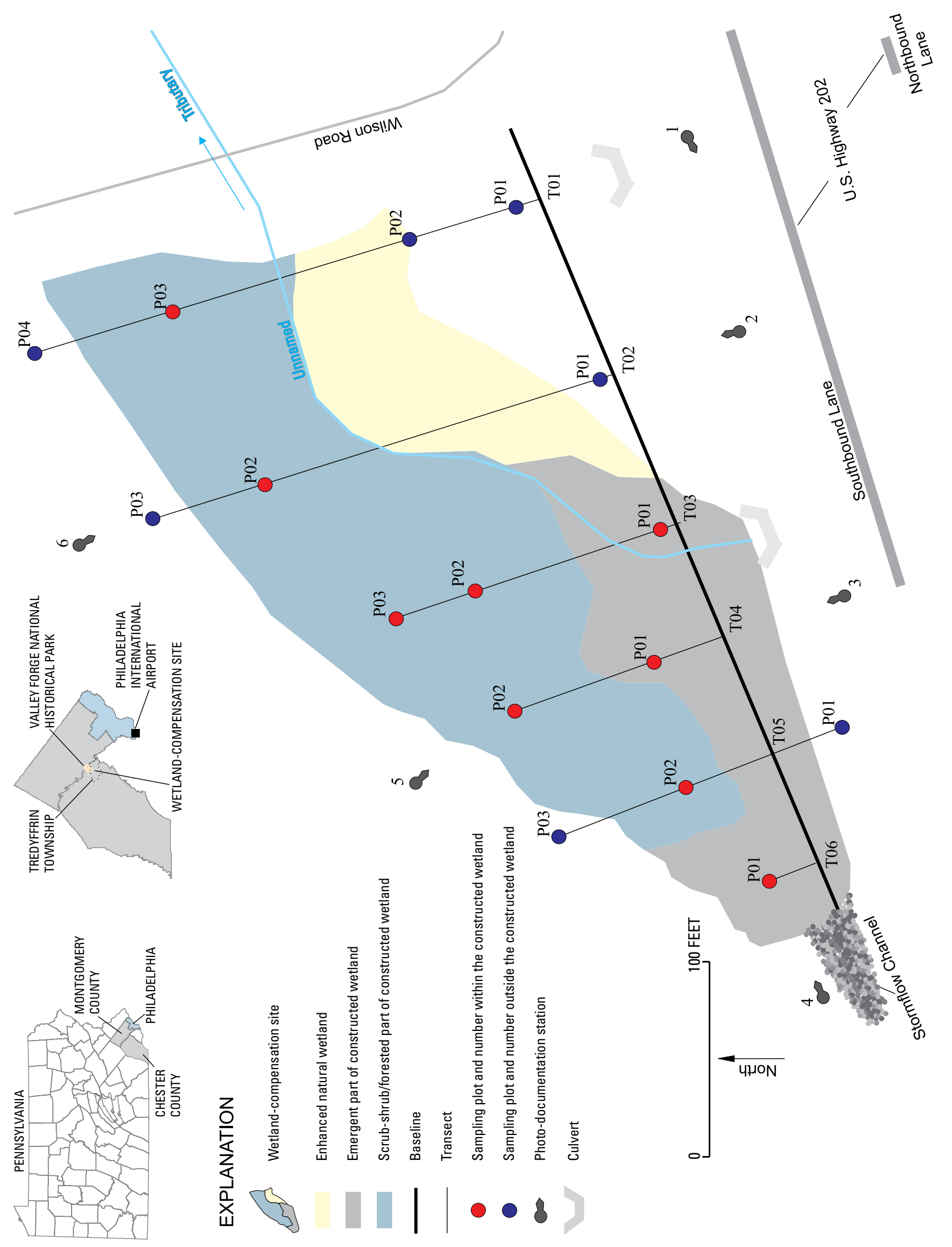

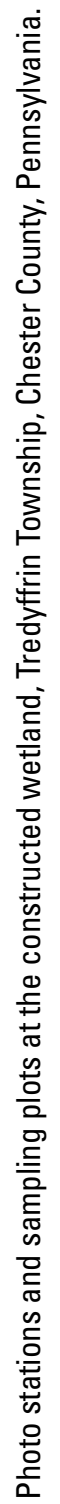

市 

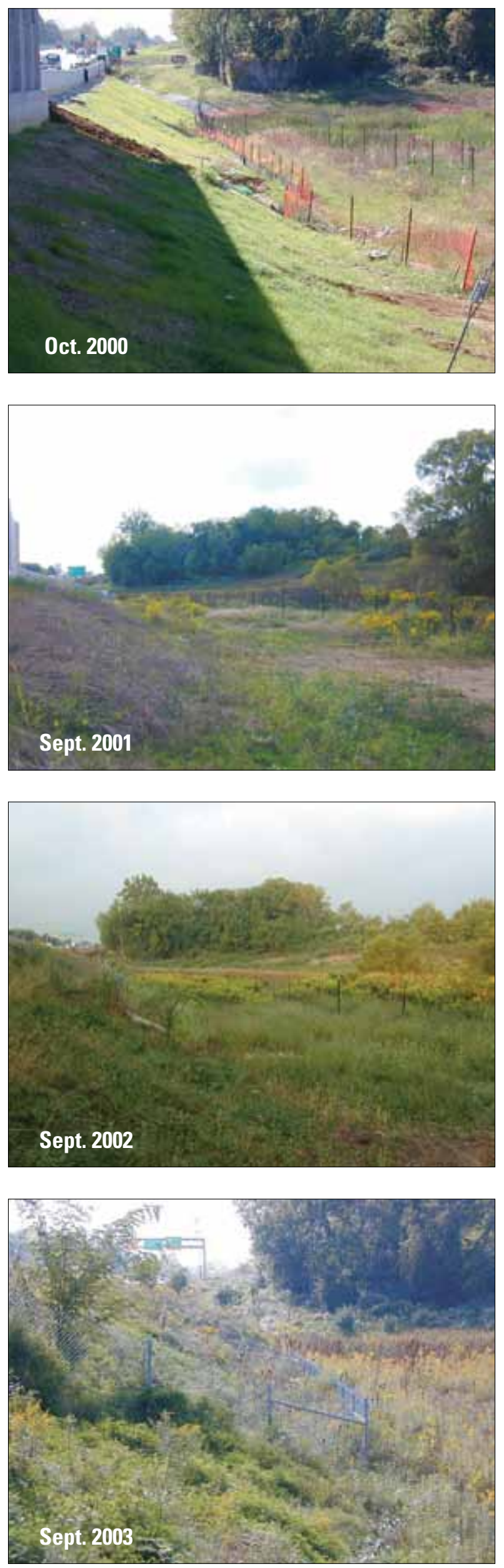
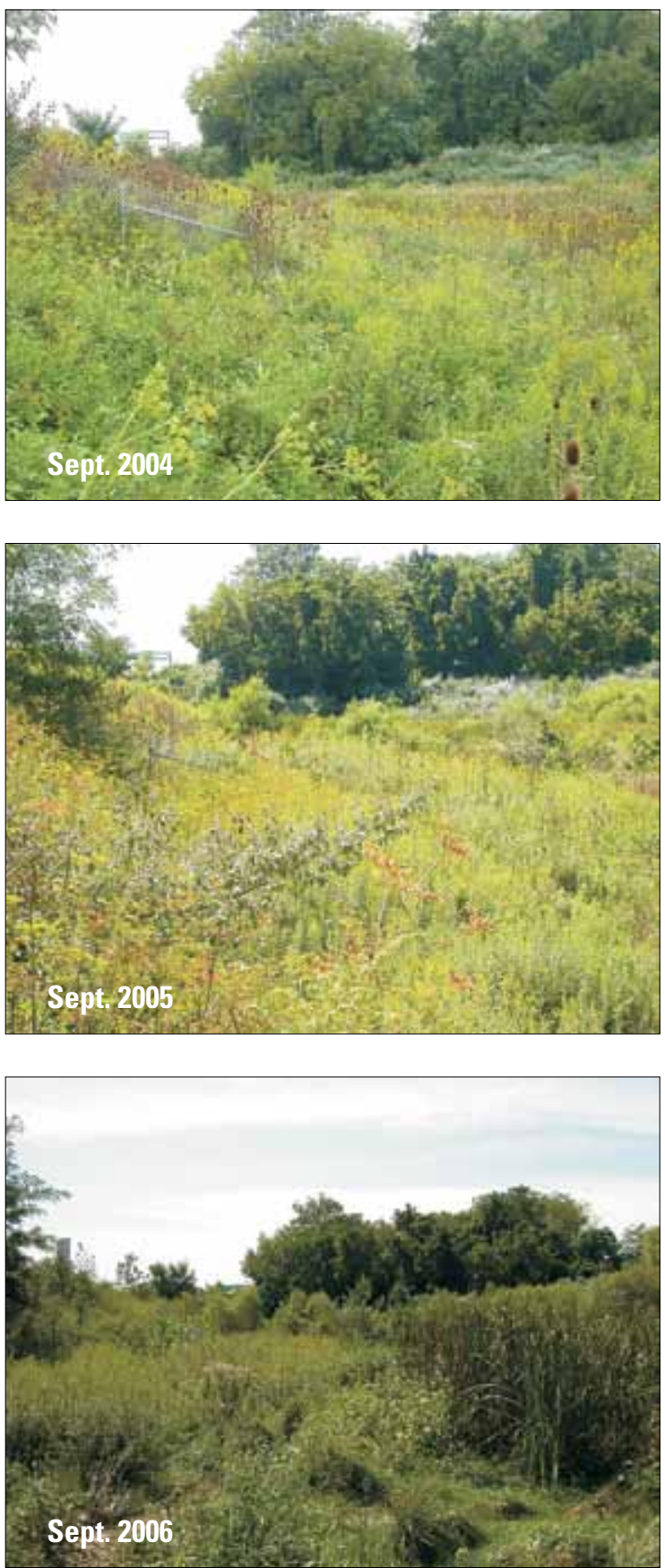

Figure 1-2. Annual views of the constructed wetland looking northeast to southwest from photo station 1 , Tredyffrin Township, Chester County, Pennsylvania. (See figure 1-1 for location and orientation of photo station.) 

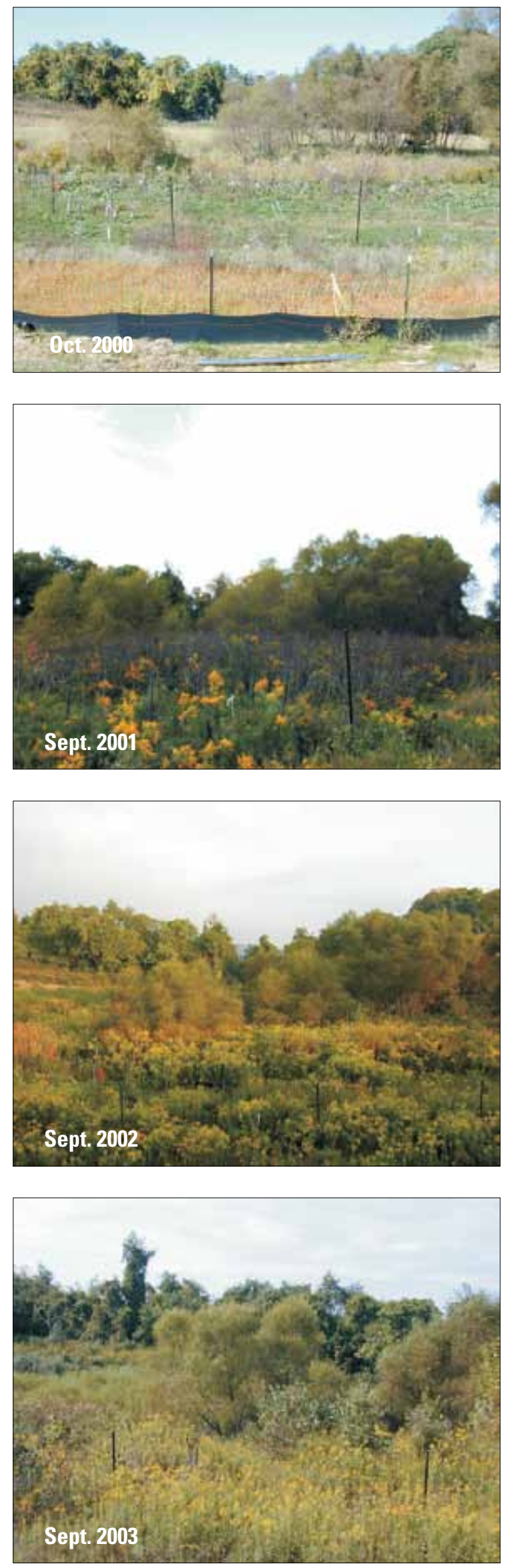
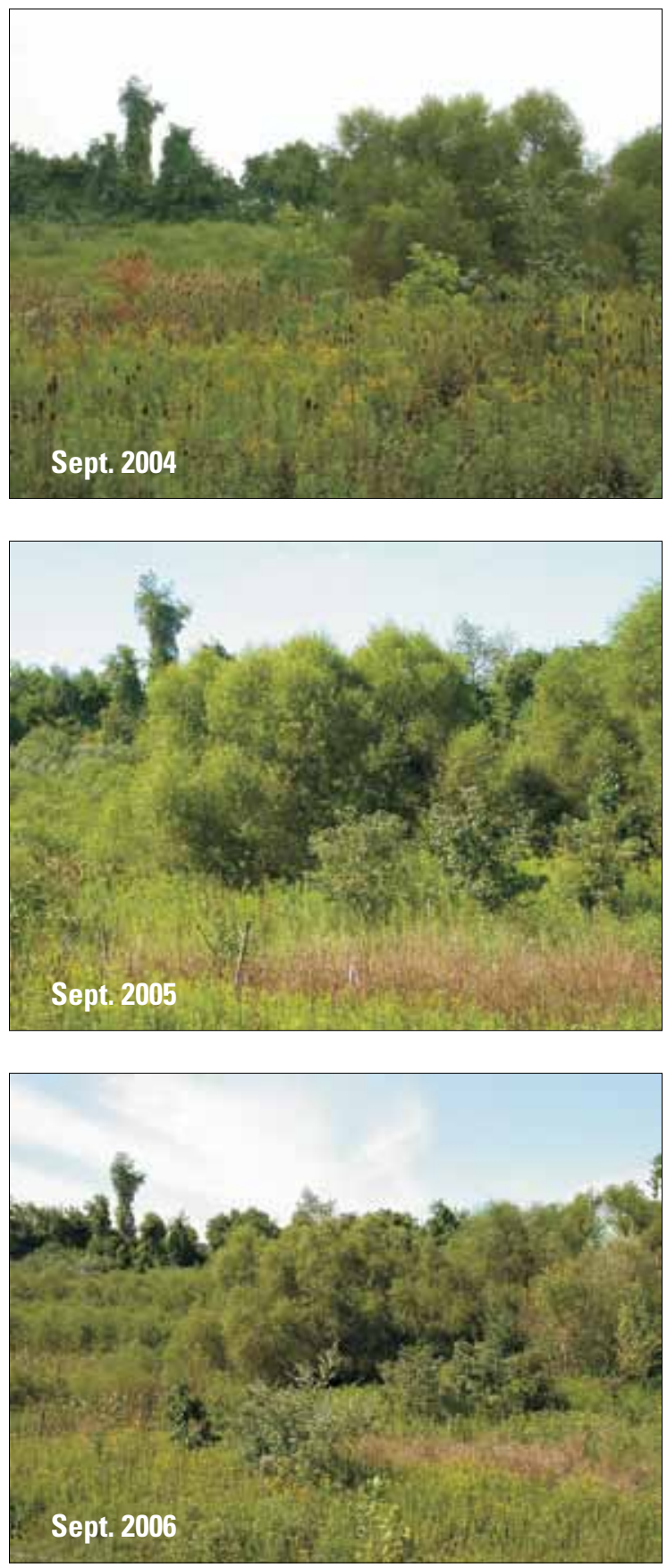

Figure 1-3. Annual views of the constructed wetland looking south to north from photo station 2, Tredyffrin Township, Chester County, Pennsylvania.

(See figure 1-1 for location and orientation of photo station.) 

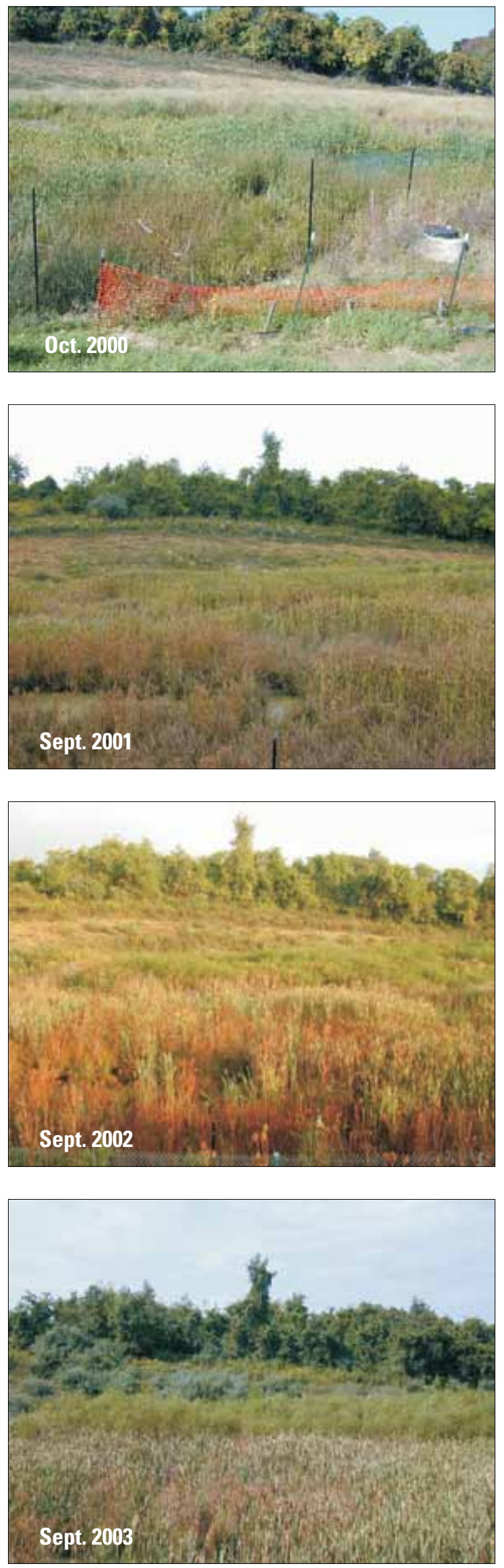
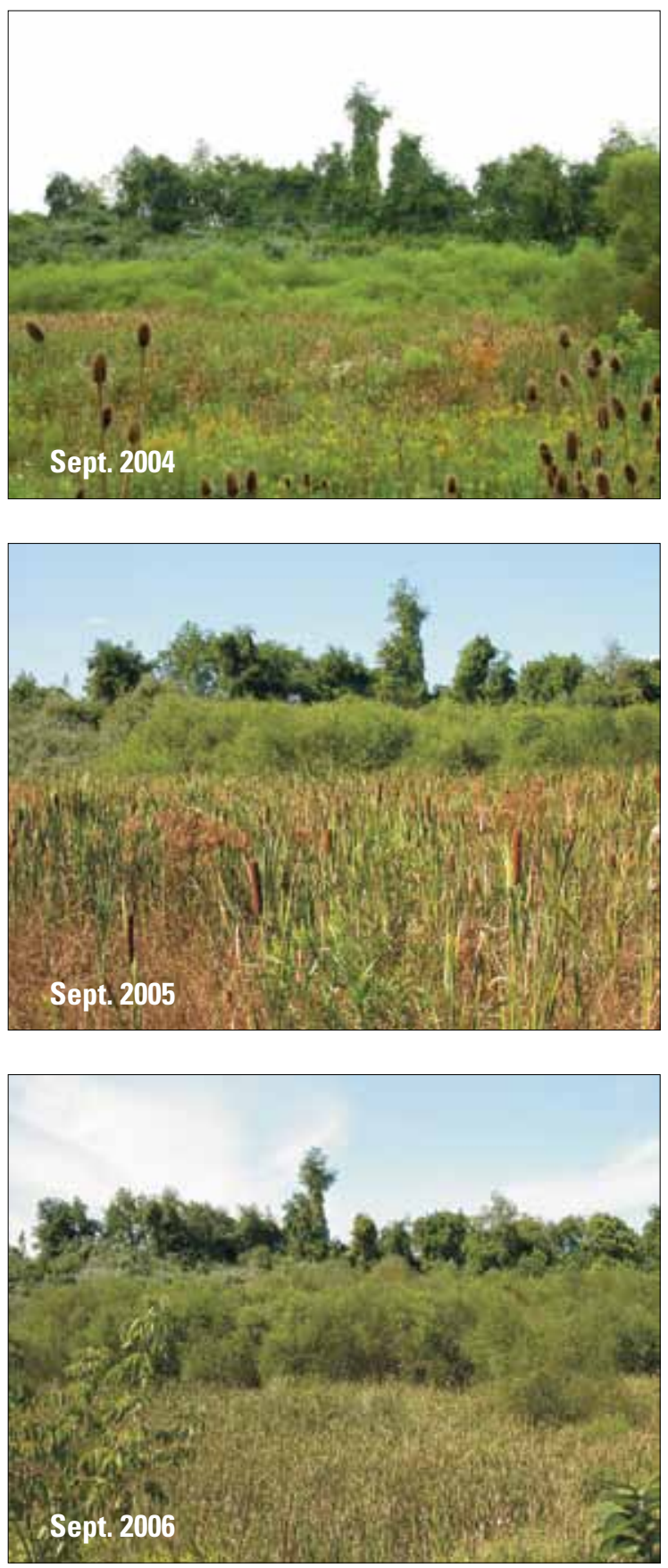

Figure 1-4. Annual views of the constructed wetland looking southeast to northwest from photo station 3 , Tredyffrin Township, Chester County, Pennsylvania. (See figure 1-1 for location and orientation of photo station.) 

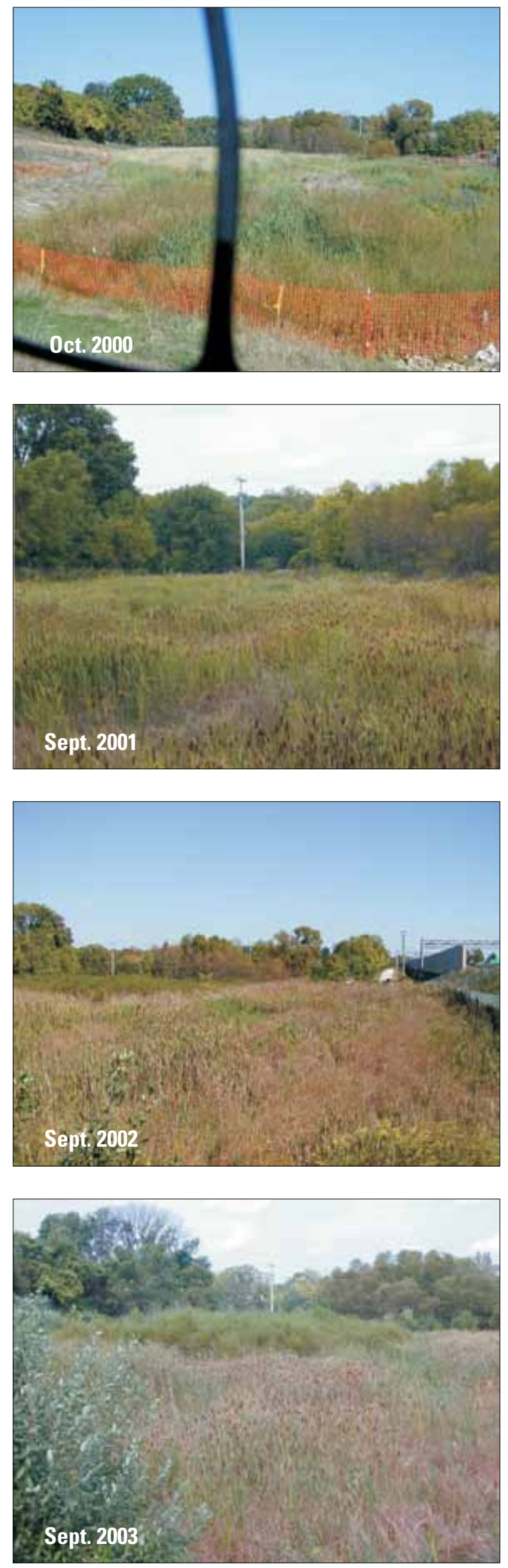
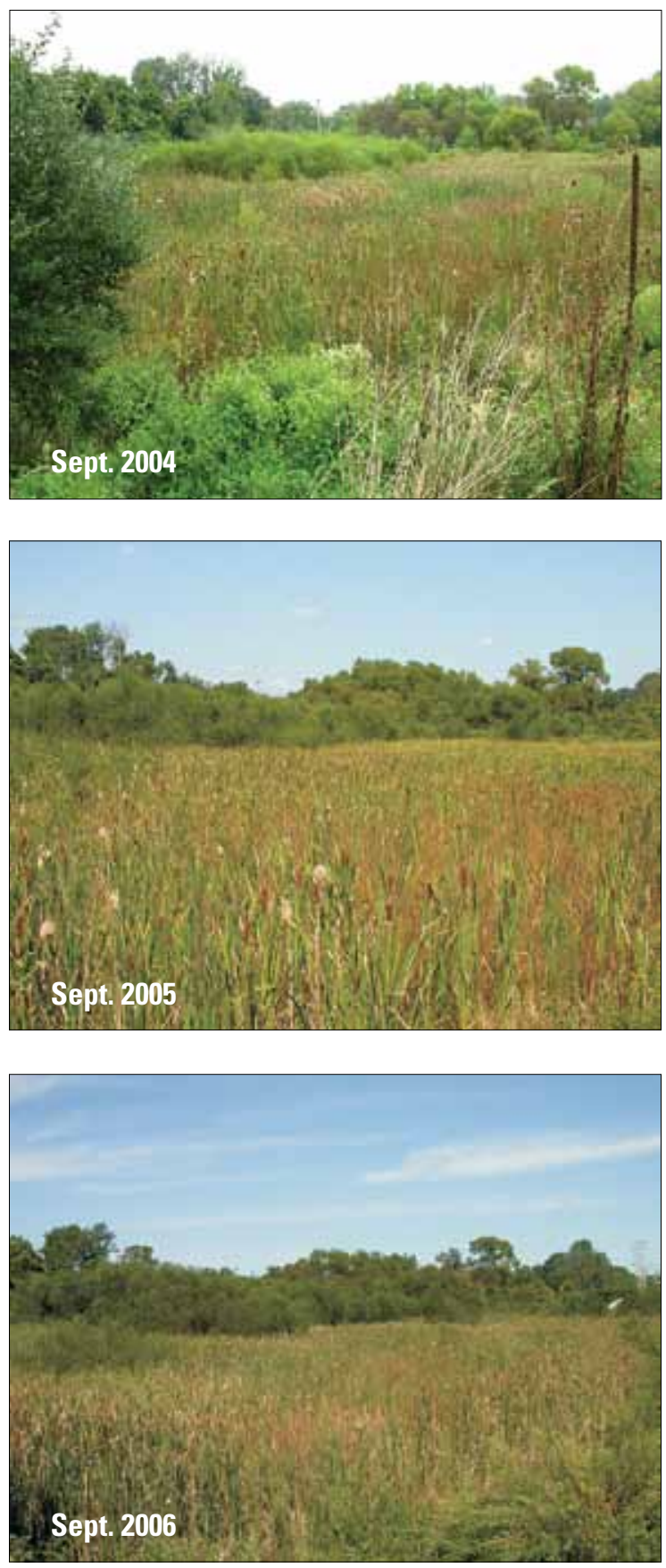

Figure 1-5. Annual views of the constructed wetland looking southwest to northeast from photo station 4, Tredyffrin Township, Chester County, Pennsylvania. (See figure 1-1 for location and orientation of photo station.) 

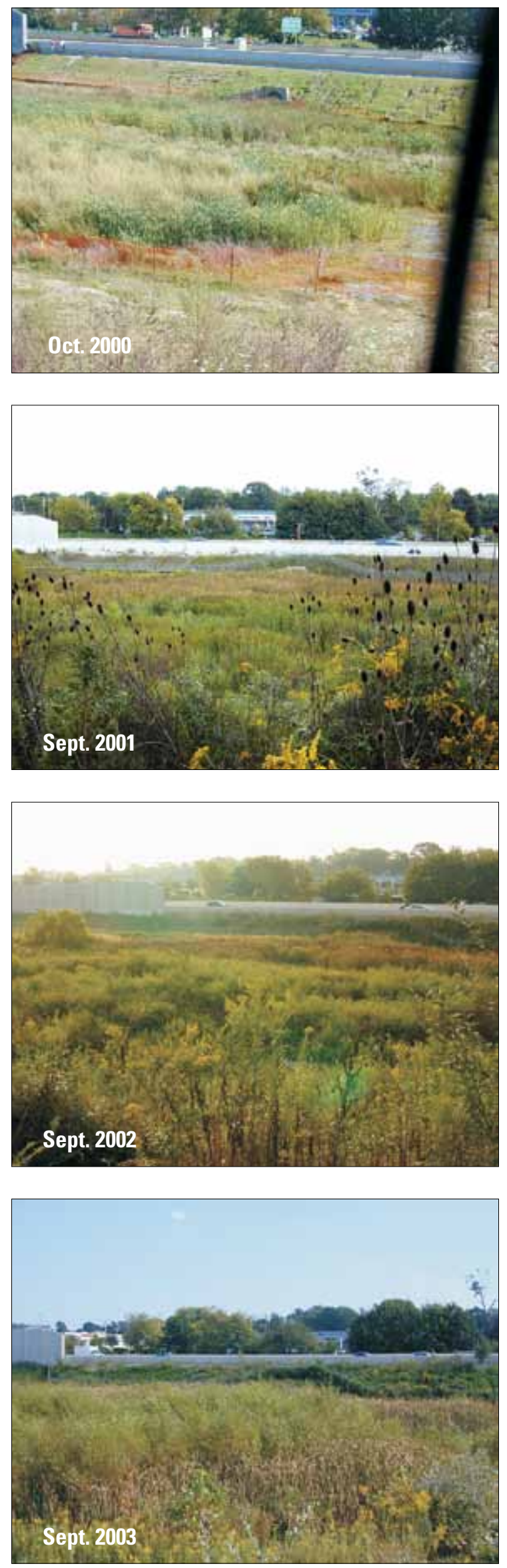
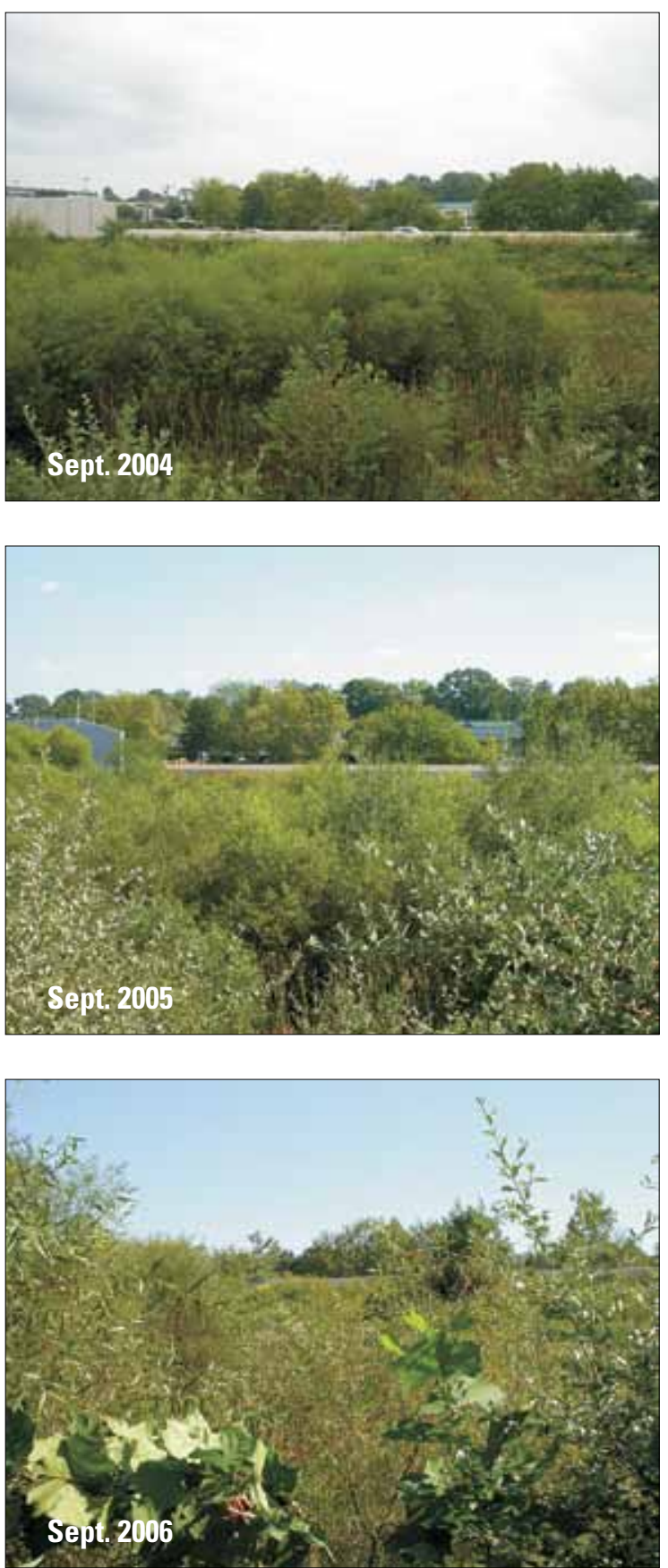

Figure 1-6. Annual views of the constructed wetland looking northwest to southeast from photo station 5, Tredyffrin Township, Chester County, Pennsylvania. (See figure 1-1 for location and orientation of photo station.) 

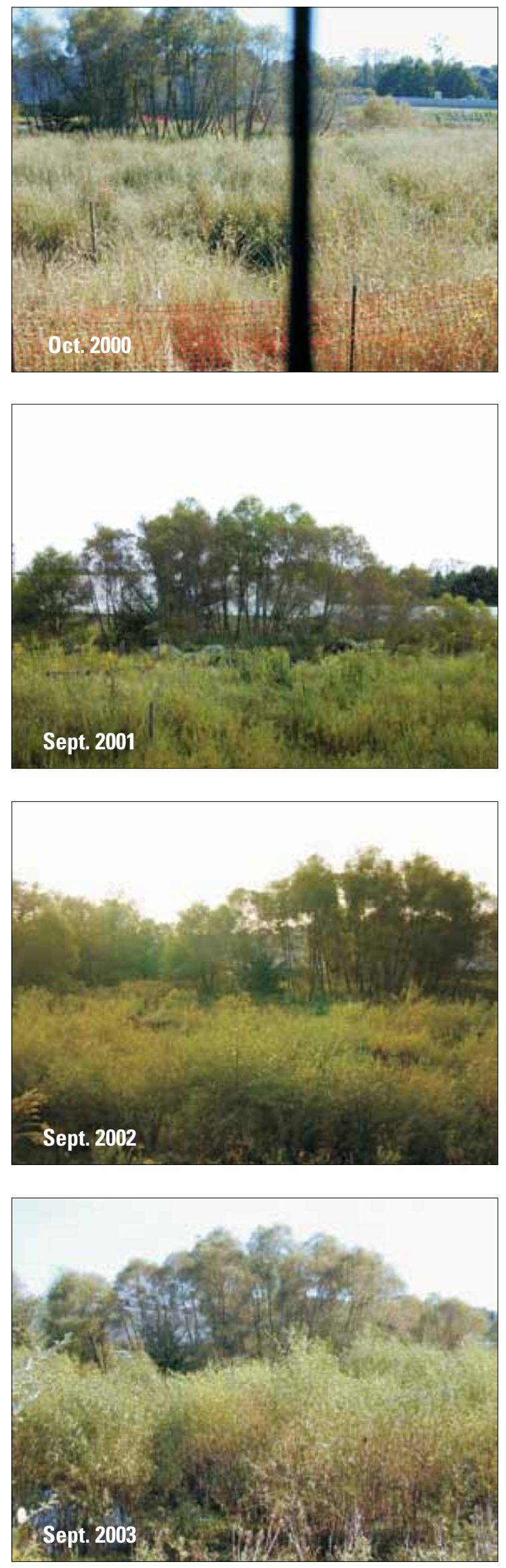
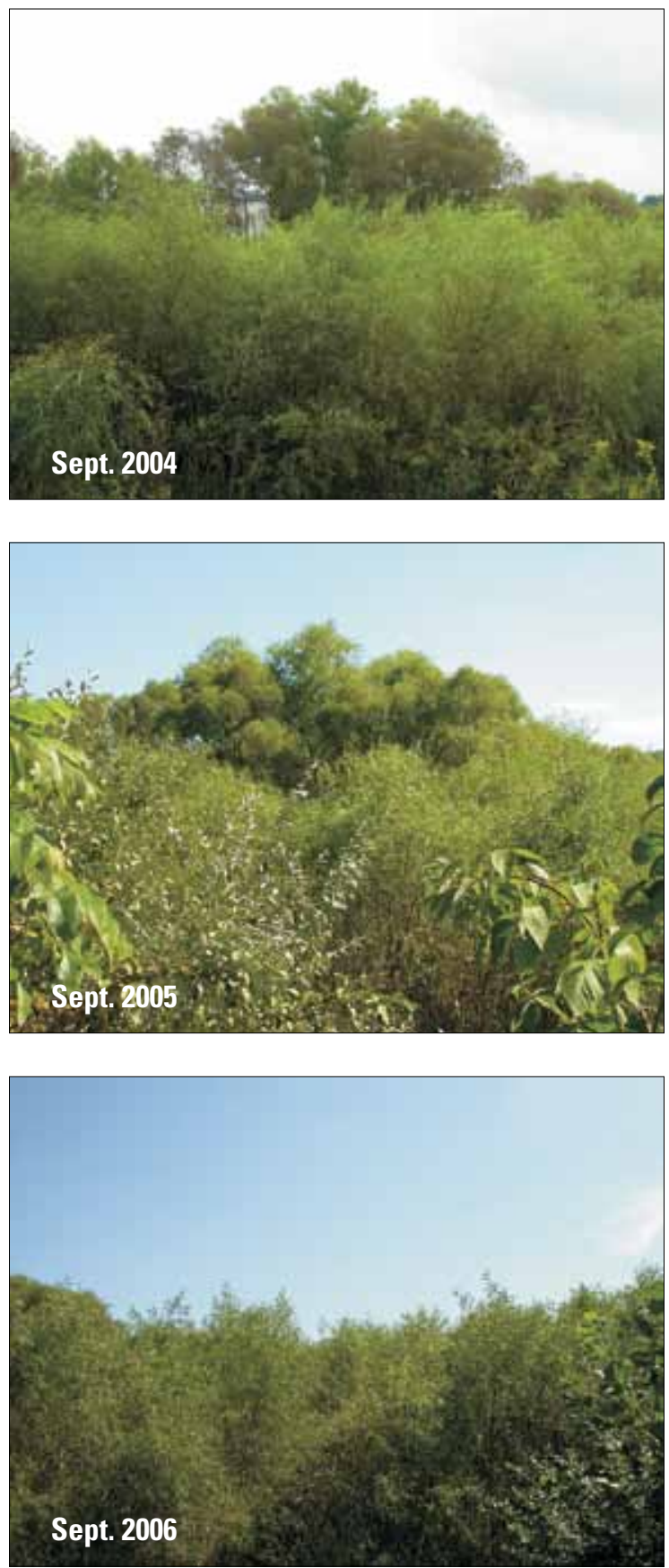

Figure 1-7. Annual views of the constructed wetland looking northwest to southeast from photo station 6, Tredyffrin Township, Chester County, Pennsylvania. (See figure 1-1 for location and orientation of photo station.) 
Appendix 2. Water Levels in Plots Outside of the Constructed Wetland 


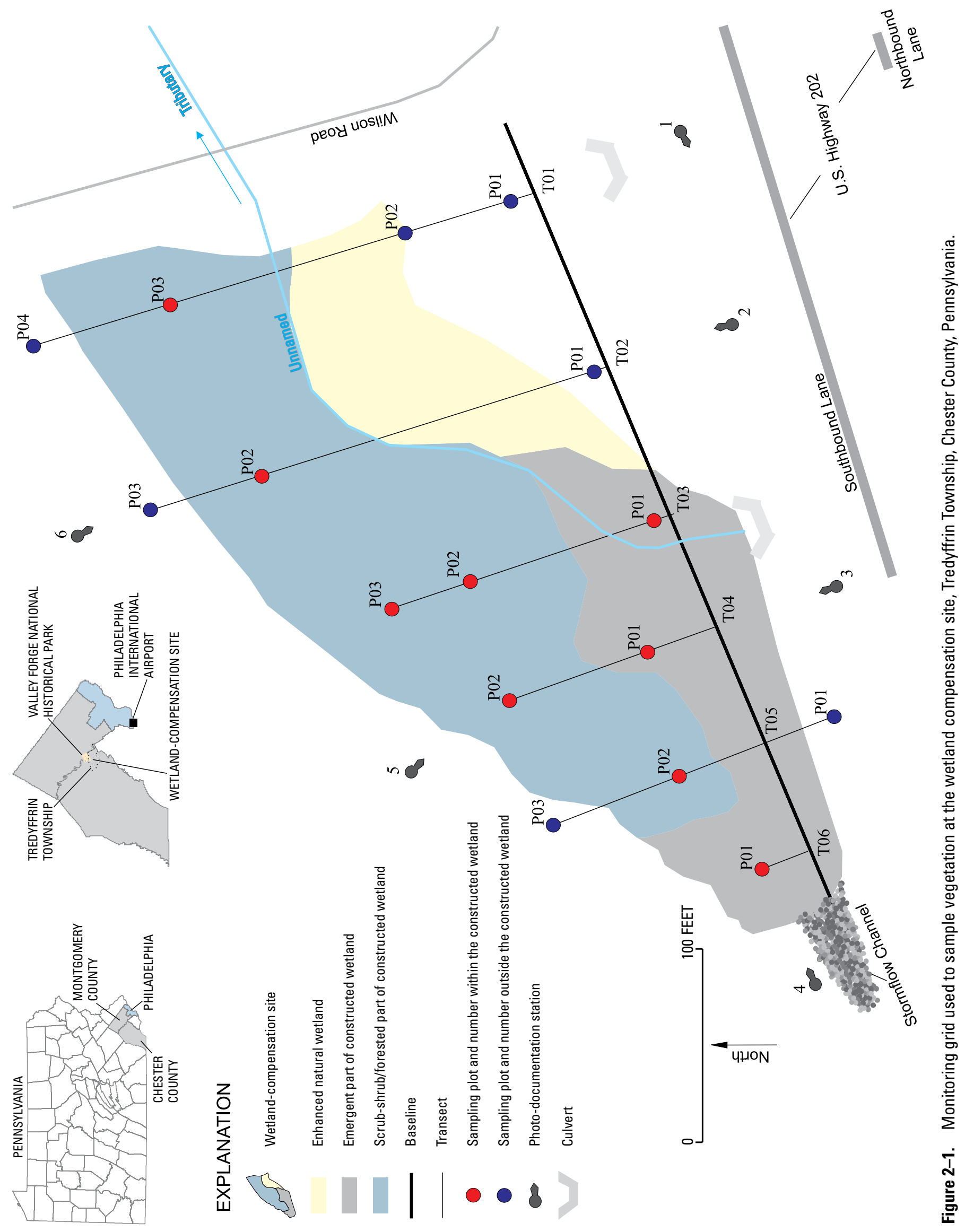




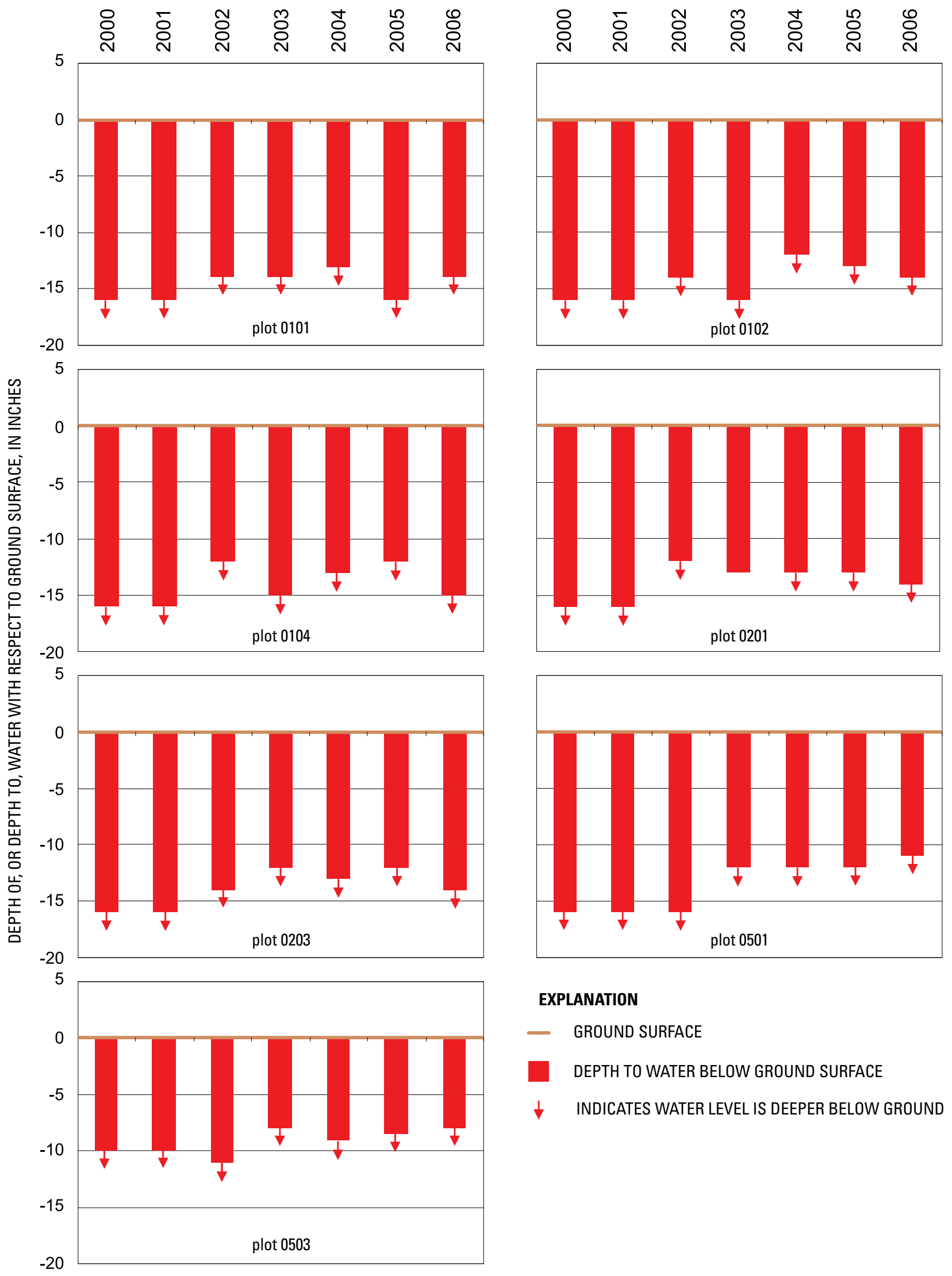

Figure 2-2. Water levels within sampling plots outside of the constructed wetland, Tredyffrin Township, Chester County, Pennsylvania, 2000-2006. 



\section{Appendix 3. Plant Species Growing in Plots Outside of the Constructed Wetland}

Table 3-1. Species richness and areal cover of vegetation growing in sampling plots outside of the constructed wetland, Tredyffrin Township, Chester County, Pennsylvania, 2000-2006.

[-, not observed; FACW, facultative-wetland species; FAC, facultative species; FACU, facultative-upland species; NI, no regional indicator status assigned, + , indicates a frequency of occurrence in the upper end of the probability range for that category; -, indicates a frequency of occurrence in the lower end of the probability range for that category; $s p$., species]

\begin{tabular}{|c|c|c|c|c|c|c|c|c|c|}
\hline \multicolumn{2}{|c|}{ Species } & \multirow{2}{*}{ Indicator } & \multicolumn{7}{|c|}{ Areal cover, in percent } \\
\hline Latin name & Common name & & 2000 & 2001 & 2002 & 2003 & 2004 & 2005 & 2006 \\
\hline Acer rubrum & red maple & FACW+ & 1 & 1 & 1 & - & - & - & - \\
\hline Agrostis alba & redtop & FACW & - & 11 & - & - & 1 & - & - \\
\hline Agrostis stolonifera & spreading bentgrass & FACW & - & - & - & 14 & 11 & 17 & 19 \\
\hline Ailanthus altissima & tree-of-heaven & NI & - & - & 1 & 3 & 4 & 2 & 1 \\
\hline Ambrosia artemisifolia & common ragweed & FACU & 2 & 2 & - & - & - & - & - \\
\hline Apocynum cannabinum & hemp-dogbane & FACU & - & - & - & 1 & 1 & 1 & 1 \\
\hline Aster novae-angliae & New England aster & FACW- & - & - & - & - & - & - & 1 \\
\hline Aster racemosus & small white aster & $\mathrm{FACW}$ & - & 3 & 1 & - & - & - & - \\
\hline Bidens frondosa & leafy beggar-ticks & FACW & 1 & - & - & - & - & - & - \\
\hline Celastrus orbiculata & Oriental Bitter-Sweet & UPL & - & 1 & 1 & - & - & - & - \\
\hline Celastrus scandens & Climbing Bittersweet & FACU- & 2 & - & - & - & 1 & 4 & 6 \\
\hline Chenopodium album & Lambsquarter & FACU+ & - & 1 & - & - & - & - & - \\
\hline Cirsium discolor & Field Thistle & NI & - & 1 & 1 & - & 11 & 4 & - \\
\hline Coronilla varia & Crown Vetch & NI & - & 1 & 15 & 16 & - & - & - \\
\hline Cornus атотит & Silky Dogwood & FACW & 3 & 1 & 1 & - & - & - & - \\
\hline Cornus racemosa (foemina) & Gray Dogwood & FAC & - & - & 1 & 10 & 4 & 2 & 1 \\
\hline Cyperus strigosus & Sedge Grass & $\mathrm{FACW}$ & 1 & - & - & - & - & - & - \\
\hline Daucus carota & Queen Ann's Lace & NI & 1 & - & - & - & - & - & - \\
\hline Dipsacus sylvestris & Teasel & NI & - & 2 & 2 & 3 & 3 & 1 & - \\
\hline Echinochloa crusgalli & Barnyard Grass & FACU & 5 & 4 & 1 & - & 0 & - & - \\
\hline Elaeagnus umbellata & Autumn-Olive & NI & 1 & 1 & 4 & 9 & 15 & 21 & 22 \\
\hline Eleocharis sp. & Spikerush Species & NI & - & - & - & - & 1 & - & - \\
\hline Eupatorium perfoliatum & Common Boneset & FACW+ & 1 & 1 & 1 & 2 & 2 & 2 & 2 \\
\hline Eupatorium rugosum & White Snakeroot & FACU- & - & - & - & 1 & 1 & - & - \\
\hline Festuca rubra & Red Fescue & FACU & - & - & 3 & 4 & 9 & - & 3 \\
\hline Impatiens capensis & Jewelweed & FACW & - & - & - & 1 & 1 & - & - \\
\hline Juglans nigra & Black Walnut & FACU & - & 6 & 1 & 1 & 3 & 4 & 1 \\
\hline Juncus tenuis & Yard Rush & FAC- & 1 & - & - & - & - & 1 & 1 \\
\hline Lobelia cardinalis & Cardinal Flower & $\mathrm{FACW}+$ & 2 & 1 & 1 & 1 & 1 & 1 & 1 \\
\hline Lolium perenne & Perennial Rye & FACU- & 26 & 4 & - & - & - & - & - \\
\hline Lonicera japonica & Japanese Honeysuckle & FAC- & - & 1 & - & - & 1 & - & 1 \\
\hline Lonicera sp. & Honeysuckle & NI & - & - & - & - & 4 & 4 & 1 \\
\hline Lotus Corniculatus & Birdsfoot Trefoil & FACU- & 23 & 20 & 11 & - & 1 & - & - \\
\hline Lycopus uniflorus & Northern Bunglewed & OBL & - & - & - & 1 & - & - & - \\
\hline Lysimachia nummularia & Moneywort & OBL & - & - & - & - & - & - & 0 \\
\hline
\end{tabular}


Table 3-1. Species richness and areal cover of vegetation growing in sampling plots outside of the constructed wetland, Tredyffrin Township, Chester County, Pennsylvania, 2000-2006.-Continued

[-, not observed; FACW, facultative-wetland species; FAC, facultative species; FACU, facultative-upland species; NI, no regional indicator status assigned, + , indicates a frequency of occurrence in the upper end of the probability range for that category; -, indicates a frequency of occurrence in the lower end of the probability range for that category; $s p$., species]

\begin{tabular}{|c|c|c|c|c|c|c|c|c|c|}
\hline \multicolumn{2}{|c|}{ Species } & \multirow{2}{*}{ Indicator } & \multicolumn{7}{|c|}{ Areal cover, in percent } \\
\hline Latin name & Common name & & 2000 & 2001 & 2002 & 2003 & 2004 & 2005 & 2006 \\
\hline Melilotus sp. & Sweet Clover & NI & - & 2 & - & - & - & - & - \\
\hline Morus rubra & Red Mulberry & FACU & 6 & 6 & 6 & 7 & 7 & 7 & 7 \\
\hline Nasturtium officinale & Watercress & OBL & 1 & - & - & - & - & - & - \\
\hline Oenothera biennis & Common Evening Primrose & FACU- & - & - & 2 & - & 1 & - & - \\
\hline Panicum dichotomiflorum & Witch Grass & FACW- & 1 & - & - & - & - & - & - \\
\hline Panicum rigidulum (stipitatum) & Red-Top Panic Grass & FACW + & - & 1 & 15 & 1 & - & - & - \\
\hline Pastinaca sativa & Parsnip & NI & - & - & - & 2 & - & - & - \\
\hline Phytolacca americana & Pokeweed & FACU+ & 3 & 1 & 2 & 1 & - & - & - \\
\hline Plantago major & Great Plantain & FACU & 1 & - & - & - & - & - & - \\
\hline Platanus occidentalis & Sycamore & FACW- & - & - & 1 & 3 & 5 & 4 & 4 \\
\hline Polygonum persicaria & Lady's Thumb & FACW & 2 & - & - & 1 & 0 & - & - \\
\hline Quercus bicolor & Swamp Oak & FACW + & 1 & 1 & 2 & 4 & 1 & 1 & 2 \\
\hline Quercus palustris & Pin Oak & FACW & - & - & 1 & - & - & - & - \\
\hline Rosa Multiflora & Multiflora Rose & FACU & 1 & - & - & 2 & 2 & 1 & 3 \\
\hline Rubus hispidus & Bristly Blackberry & FACW & - & - & - & 4 & 2 & 1 & 1 \\
\hline Rubus occidentalis & Black Raspberry & NI & 4 & 3 & 2 & 1 & 1 & 4 & 1 \\
\hline Salix nigra & Black Willow & FACW + & 6 & 6 & 4 & 4 & 3 & 3 & 4 \\
\hline Scirpus cyperinus & Woolgrass & FACW + & - & - & - & - & 1 & - & - \\
\hline Setaria faberi & Foxtail & UPL & 2 & 1 & - & - & - & - & - \\
\hline Solidago canadensis & Canada Goldenrod & FACU & 9 & 7 & 11 & 22 & 11 & 12 & 17 \\
\hline Thaspium trifoliatum & Woodland Meadow Parsnip & NI & - & - & - & - & - & 2 & 2 \\
\hline Trifolium pratense & Red Clover & FACU- & - & - & - & 1 & - & - & - \\
\hline Trifolium repens & White Clover & FACU- & - & 6 & - & - & 2 & - & - \\
\hline Triodia flava & Purpletop & NI & - & - & - & - & 8 & 6 & 5 \\
\hline Typha latifolia & Broadleaf Cattail & OBL & 1 & 1 & 1 & 3 & 6 & 6 & 4 \\
\hline Ulmus rubra & Red Elm & FAC & - & - & - & - & - & 1 & 1 \\
\hline Viburnum dentatum & Arrowwood & FAC & 1 & - & 1 & - & 0 & - & - \\
\hline Vitis spp. & Grape & NI & 2 & 4 & 1 & 9 & 9 & 10 & 3 \\
\hline Cumulative Areal Cover & & & 111 & 101 & 95 & 132 & 134 & 122 & 113 \\
\hline
\end{tabular}


Appendix 4. Photographs of Surveyed Cross Sections and Rock Deflectors in Valley Creek, Tredyffren Township, Chester County, Pennsylvania 


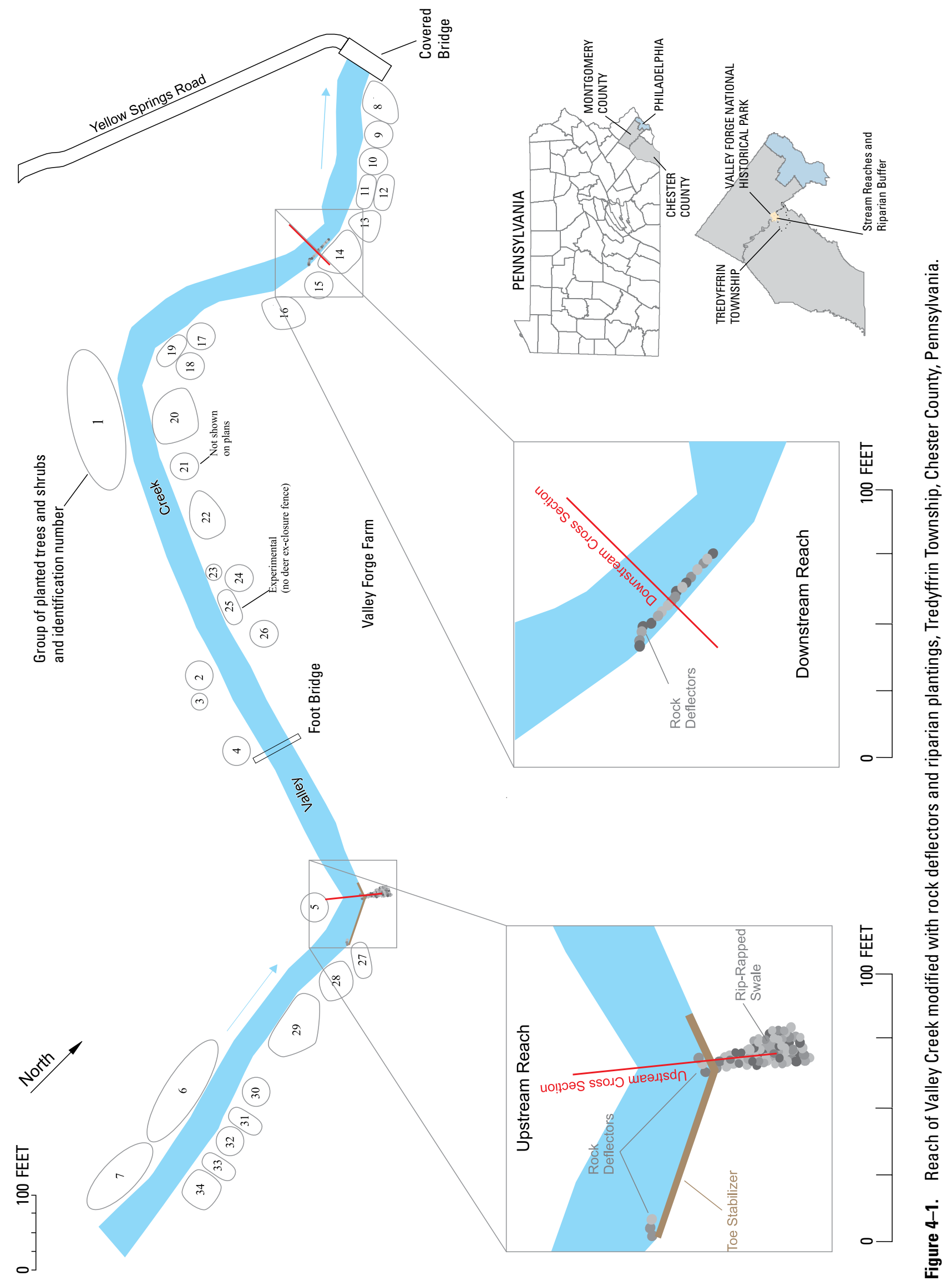



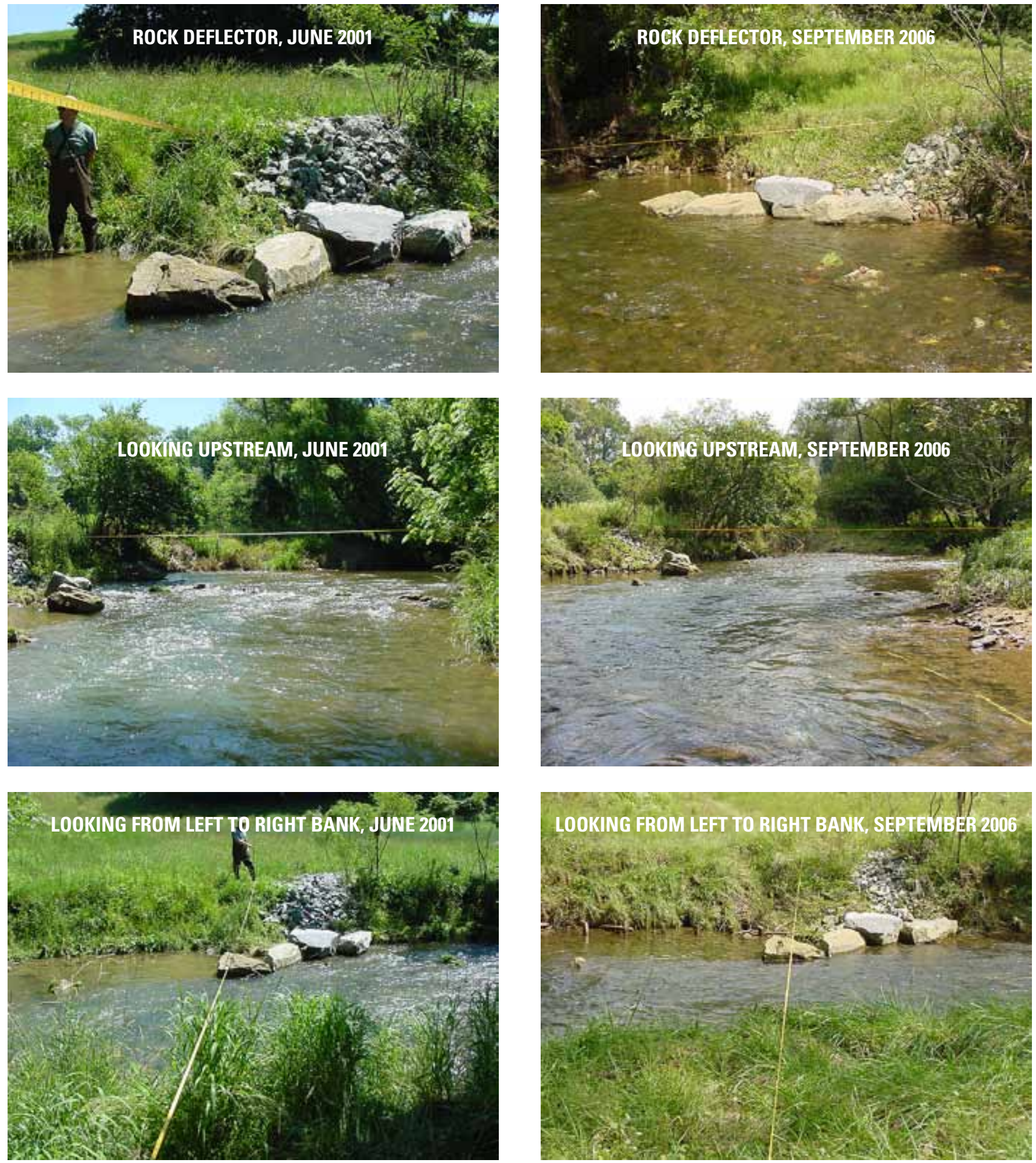

Figure 4-2. Views of the upstream rock deflector and cross section during the initial survey in June 2001 and last survey in September 2006. 

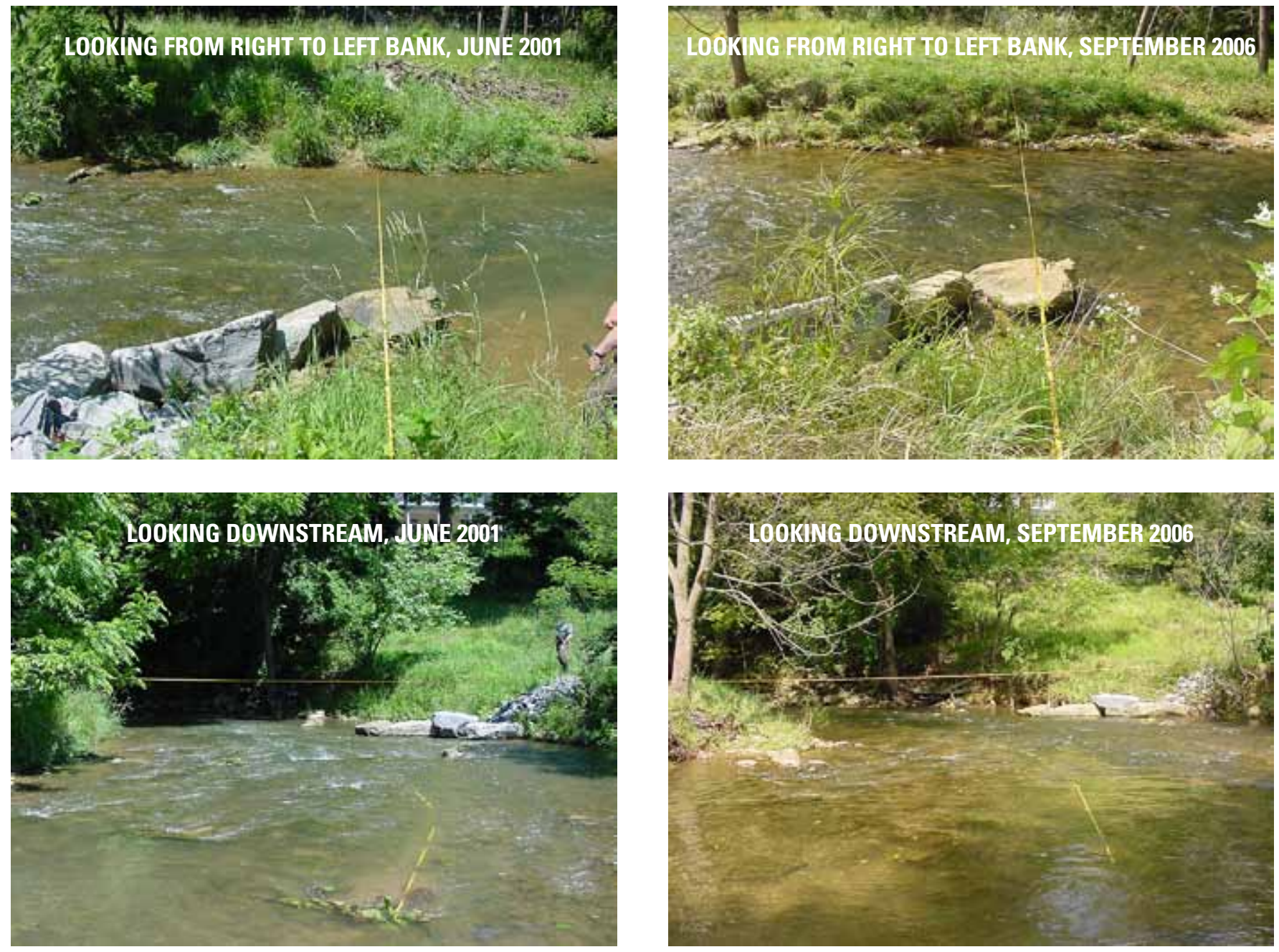

Figure 4-2. Views of the upstream rock deflector and cross section during the initial survey in June 2001 and last survey in September 2006.-Continued 

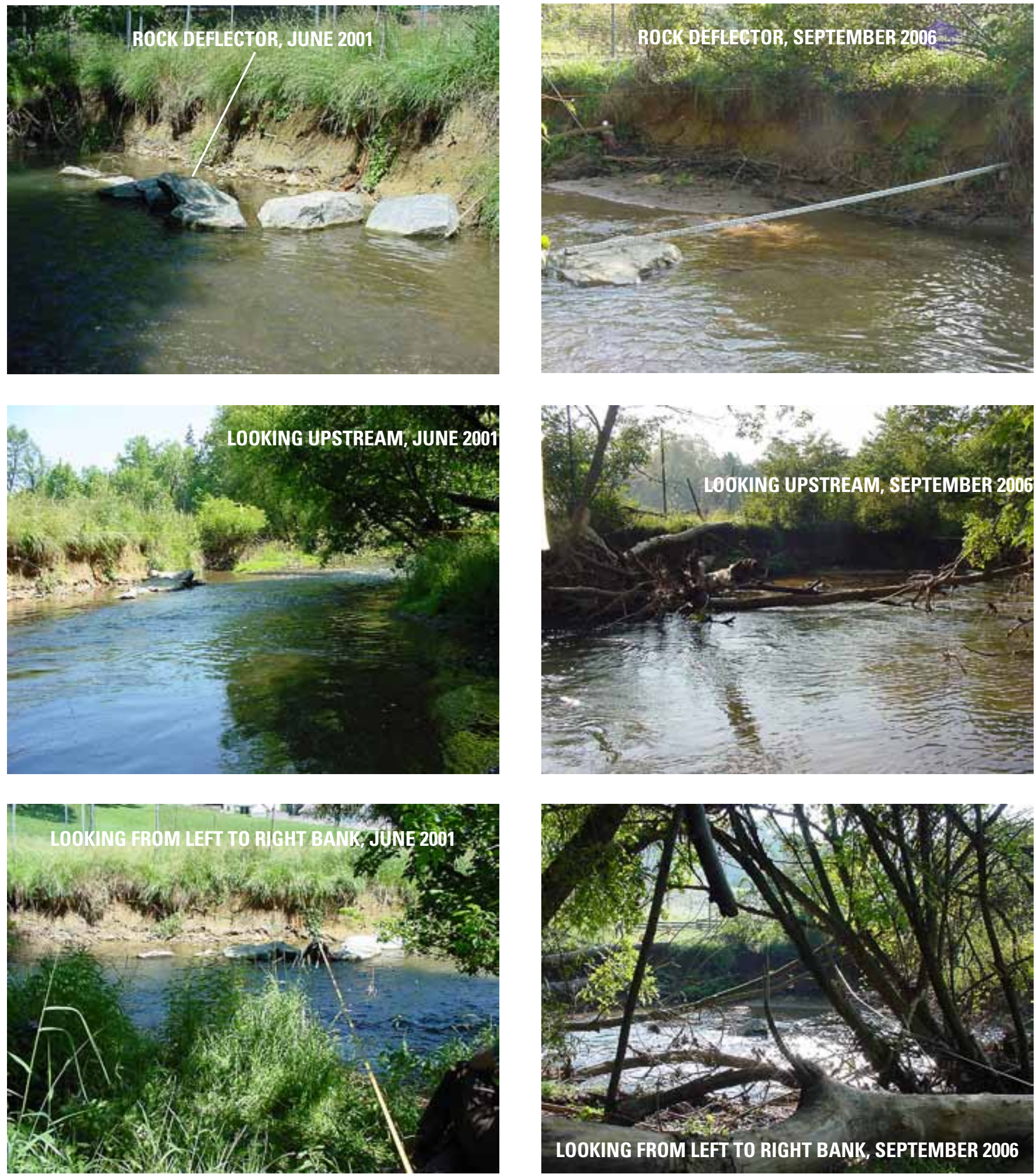

Figure 4-3. Views of the downstream rock deflector and cross section during the initial survey in June 2001 and last survey in September 2006. 

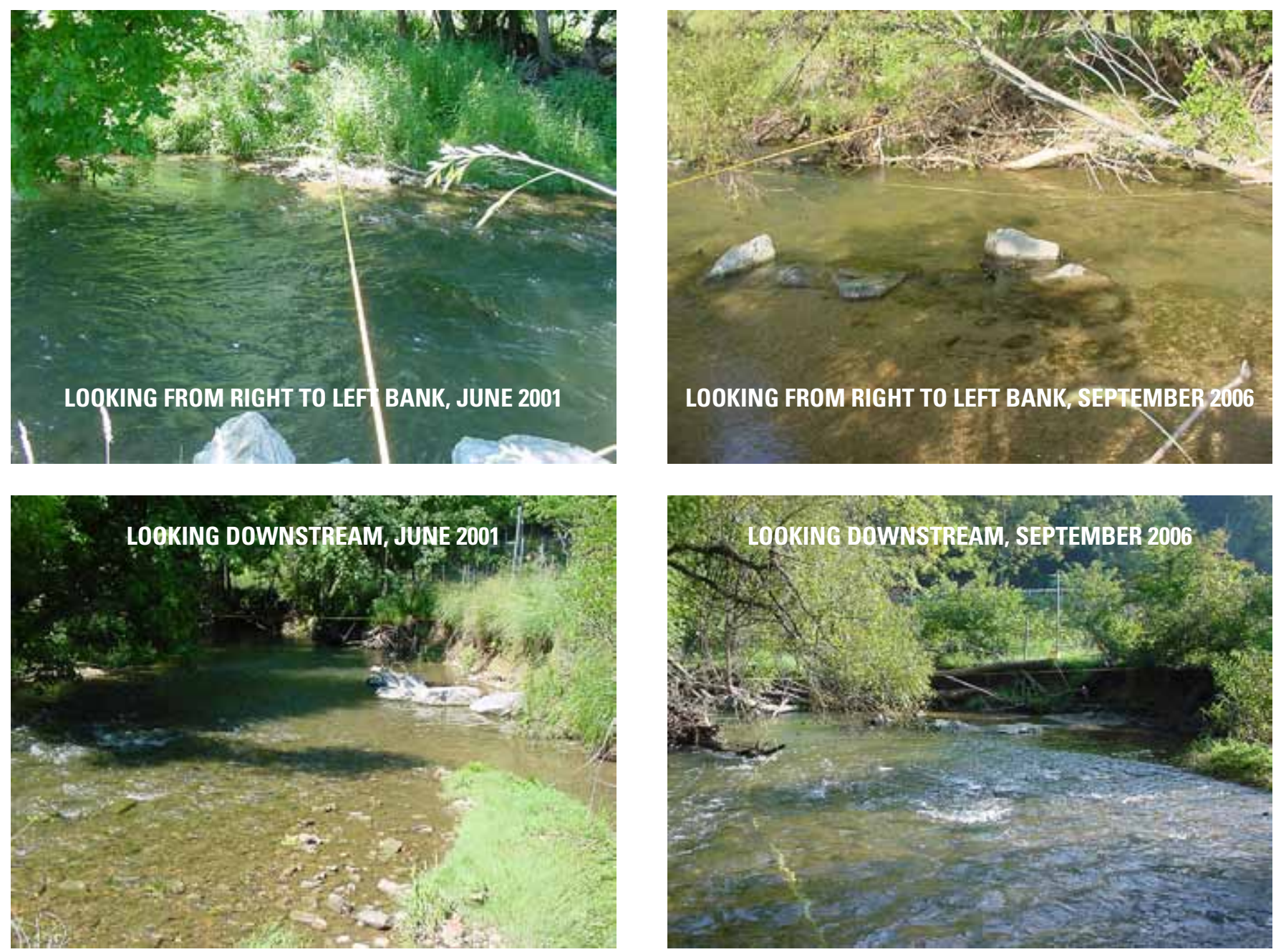

Figure 4-3. Views of the downstream rock deflector and cross section during the initial survey in June 2001 and last survey in September 2006.-Continued 


\section{Appendix 5. Photographs of Selected Tree and Shrub Plantings in the Riparian Buffer, Tredyffrin Township, Chester County, Pennsylvania}




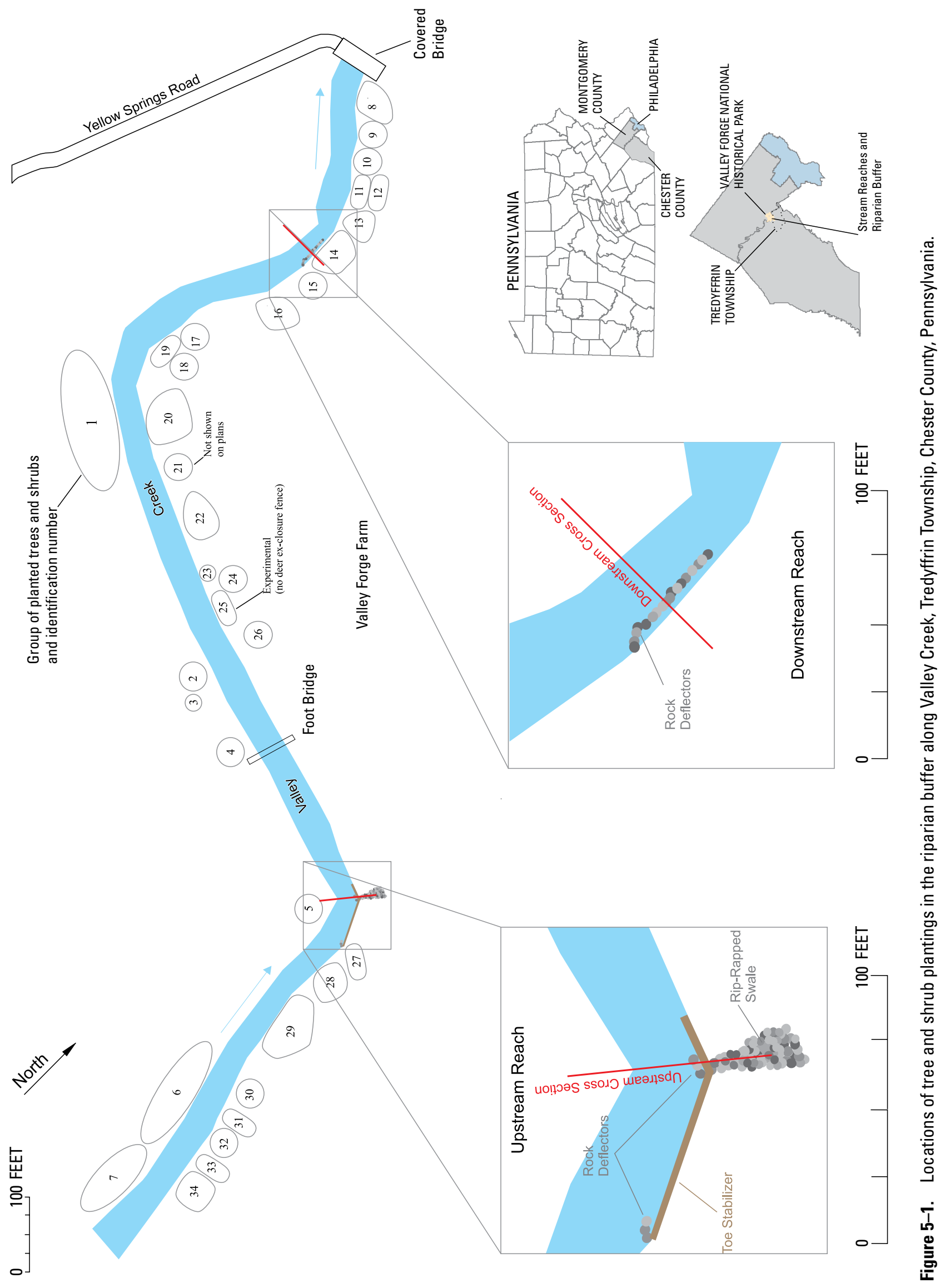



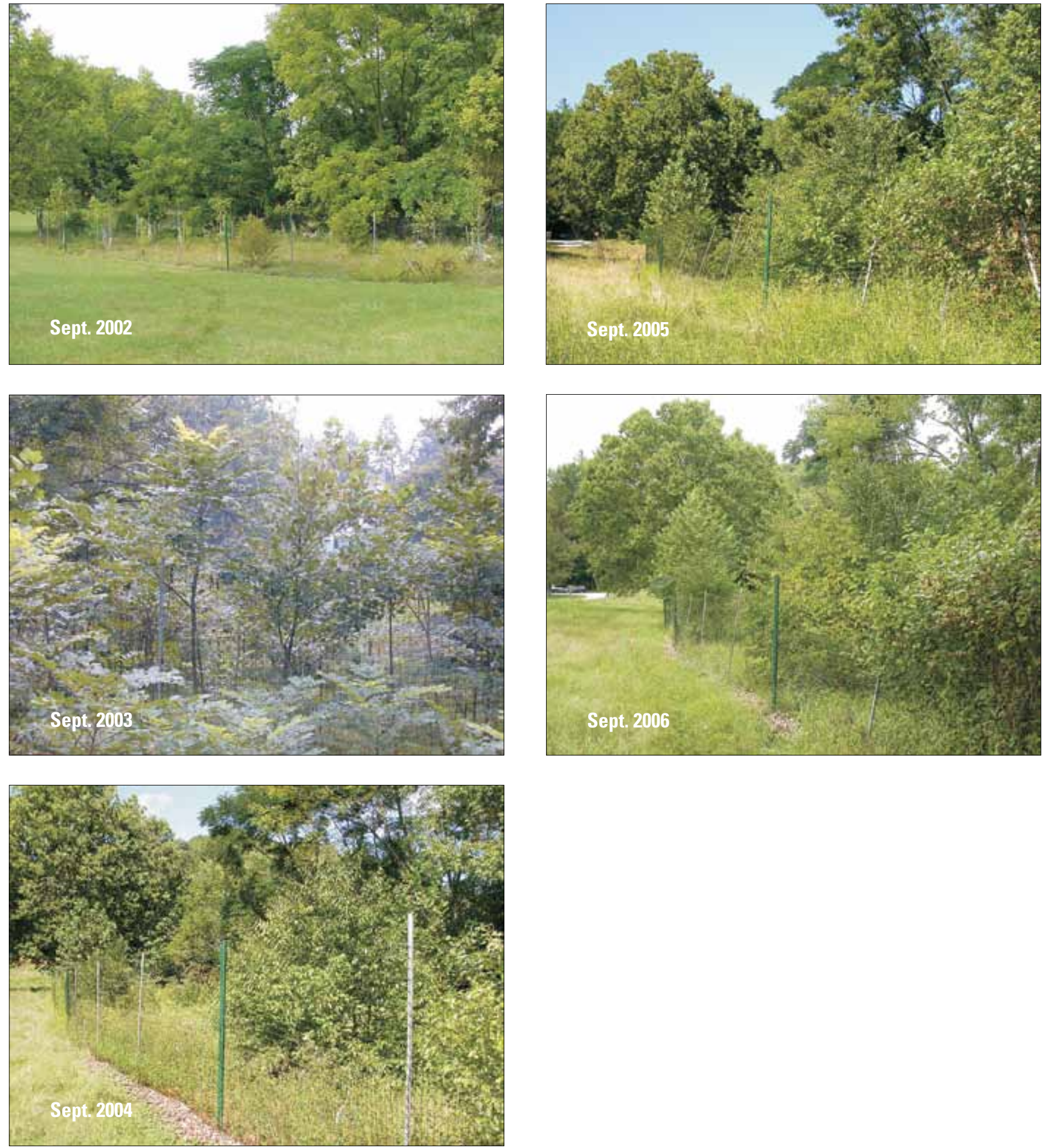

Figure 5-2. Annual views of riparian-buffer plantings in group 1, Tredyffrin Township, Chester County, Pennsylvania. (See figure 5-1 for location.) 

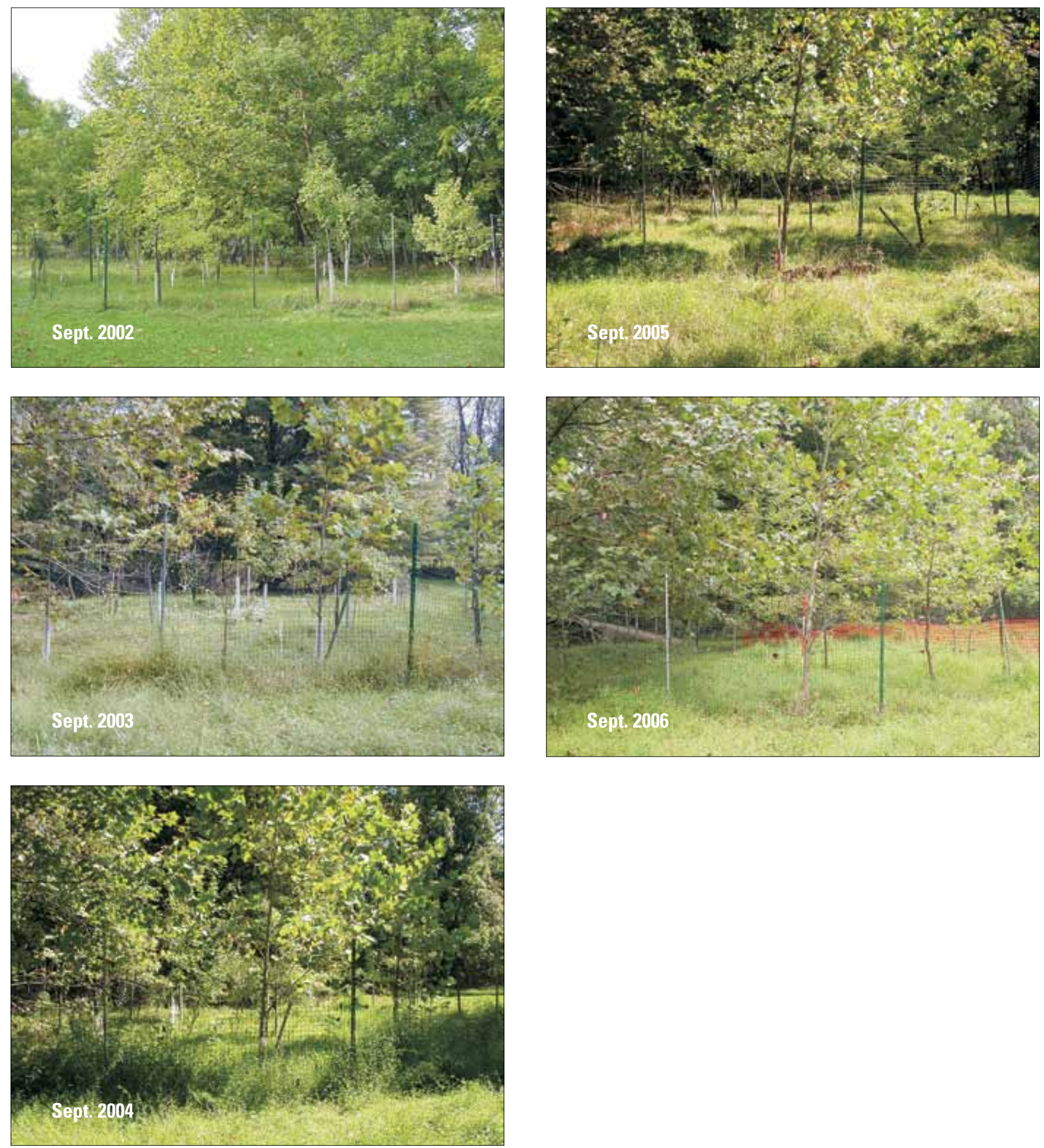

Figure 5-3. Annual views of riparian-buffer plantings in group 4, Tredyffrin Township, Chester County, Pennsylvania. (See figure 5-1 for location.) 

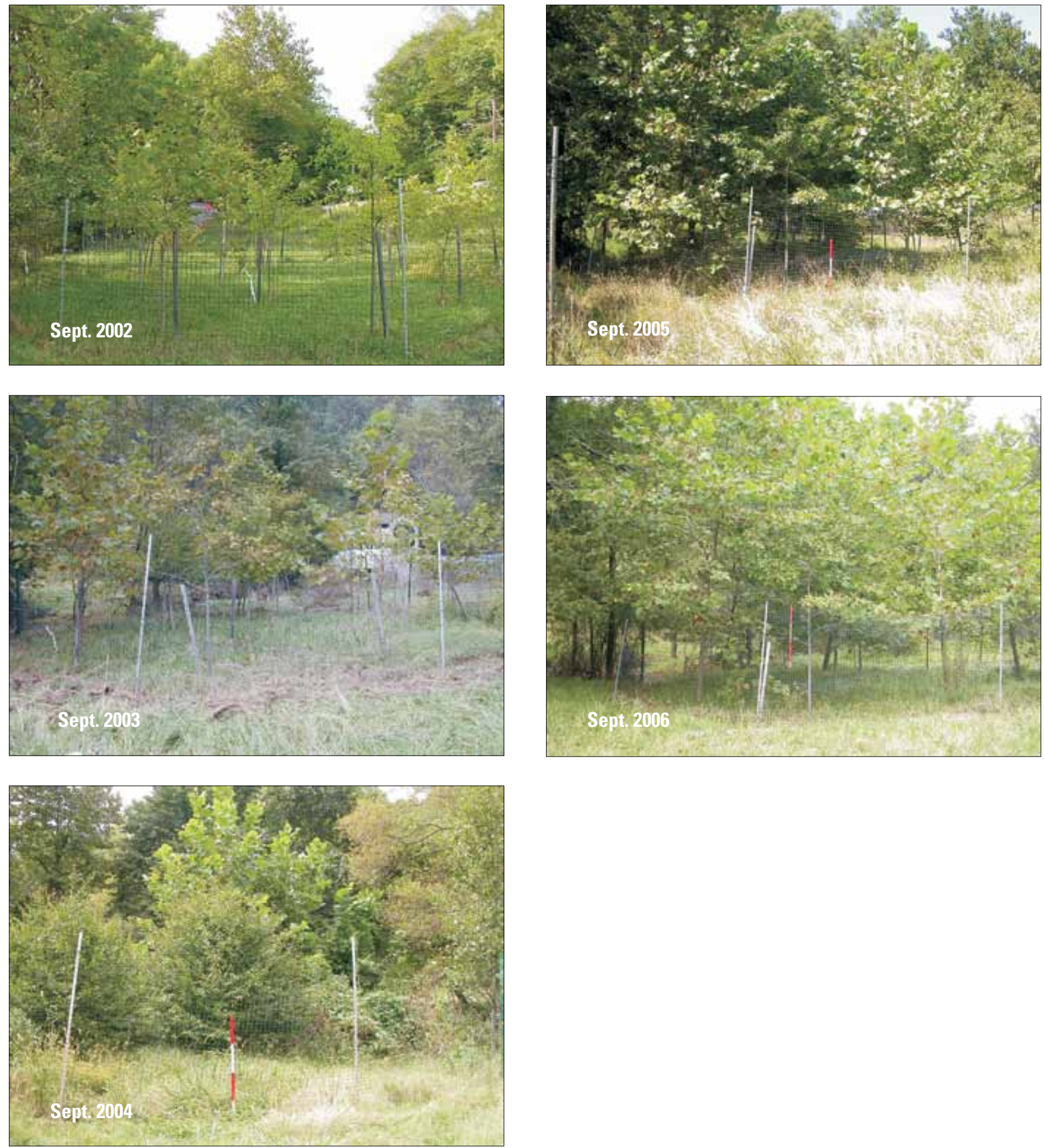

Figure 5-4. Annual views of riparian-buffer plantings in group 10, Tredyffrin Township, Chester County, Pennsylvania. (See figure 5-1 for location.) 

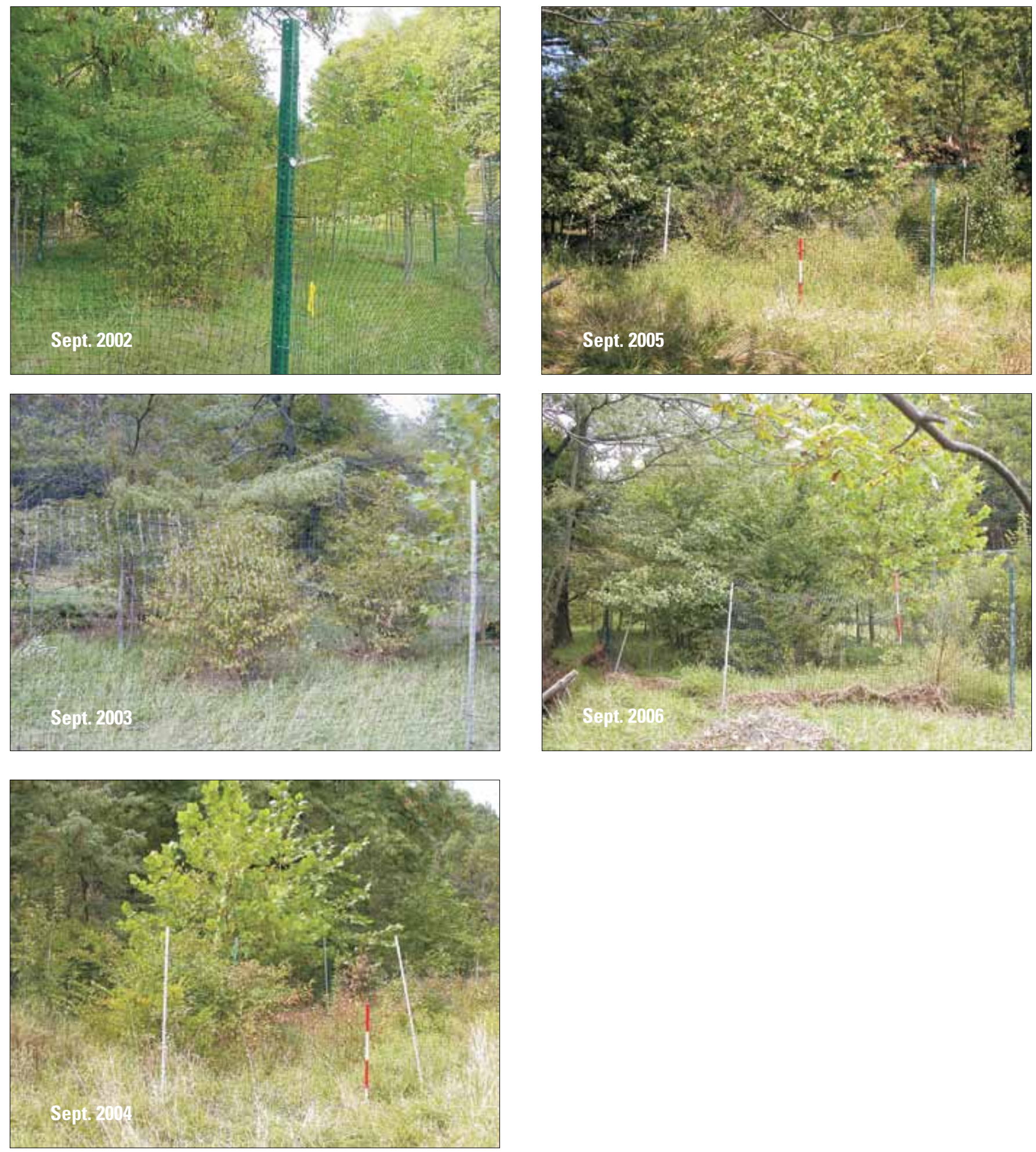

Figure 5-5. Annual views of riparian-buffer plantings in group 11, Tredyffrin Township, Chester County, Pennsylvania. (See figure 5-1 for location.) 

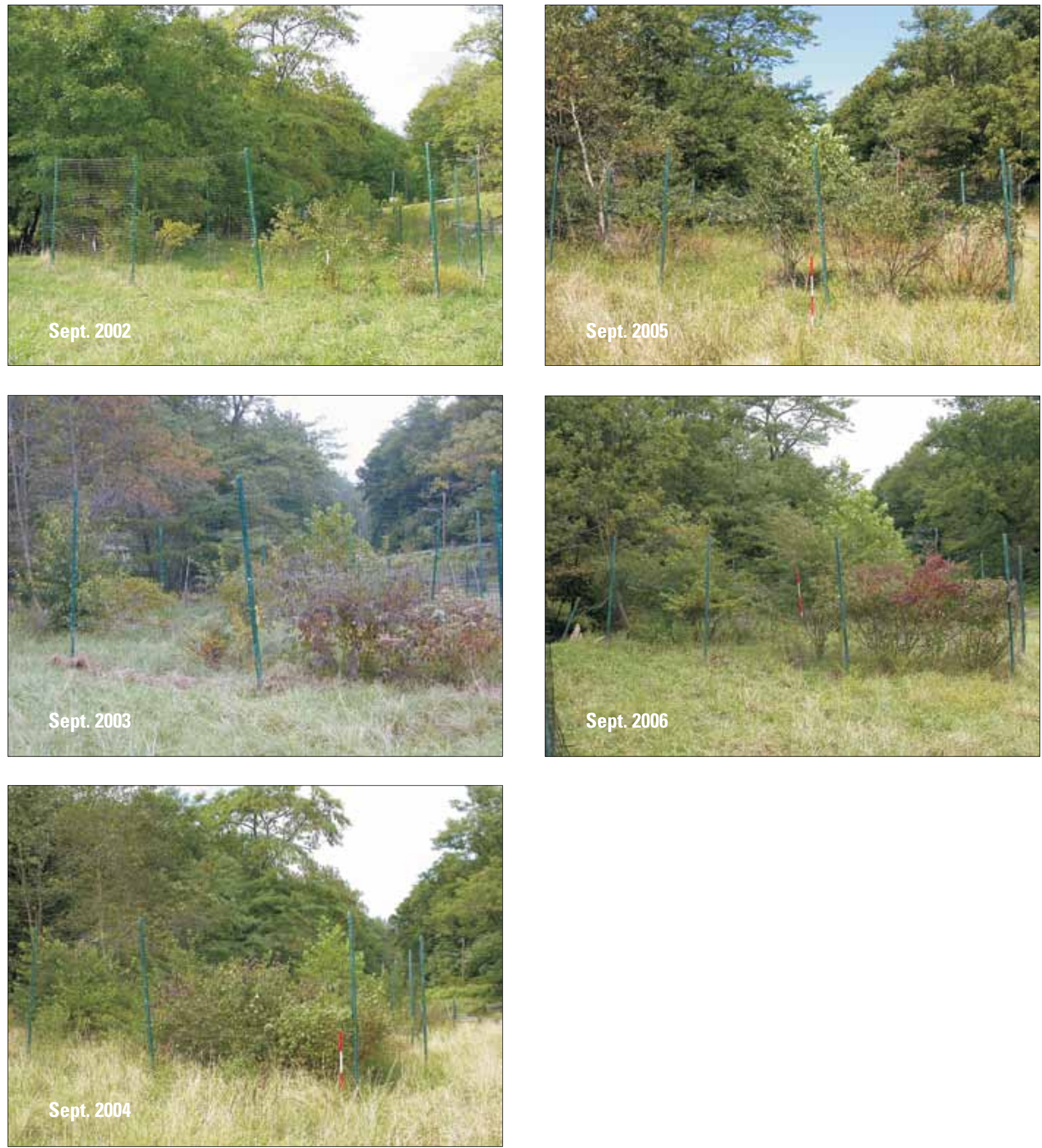

Figure 5-6. Annual views of riparian-buffer plantings in group 13, Tredyffrin Township, Chester County, Pennsylvania. (See figure 5-1 for location.) 

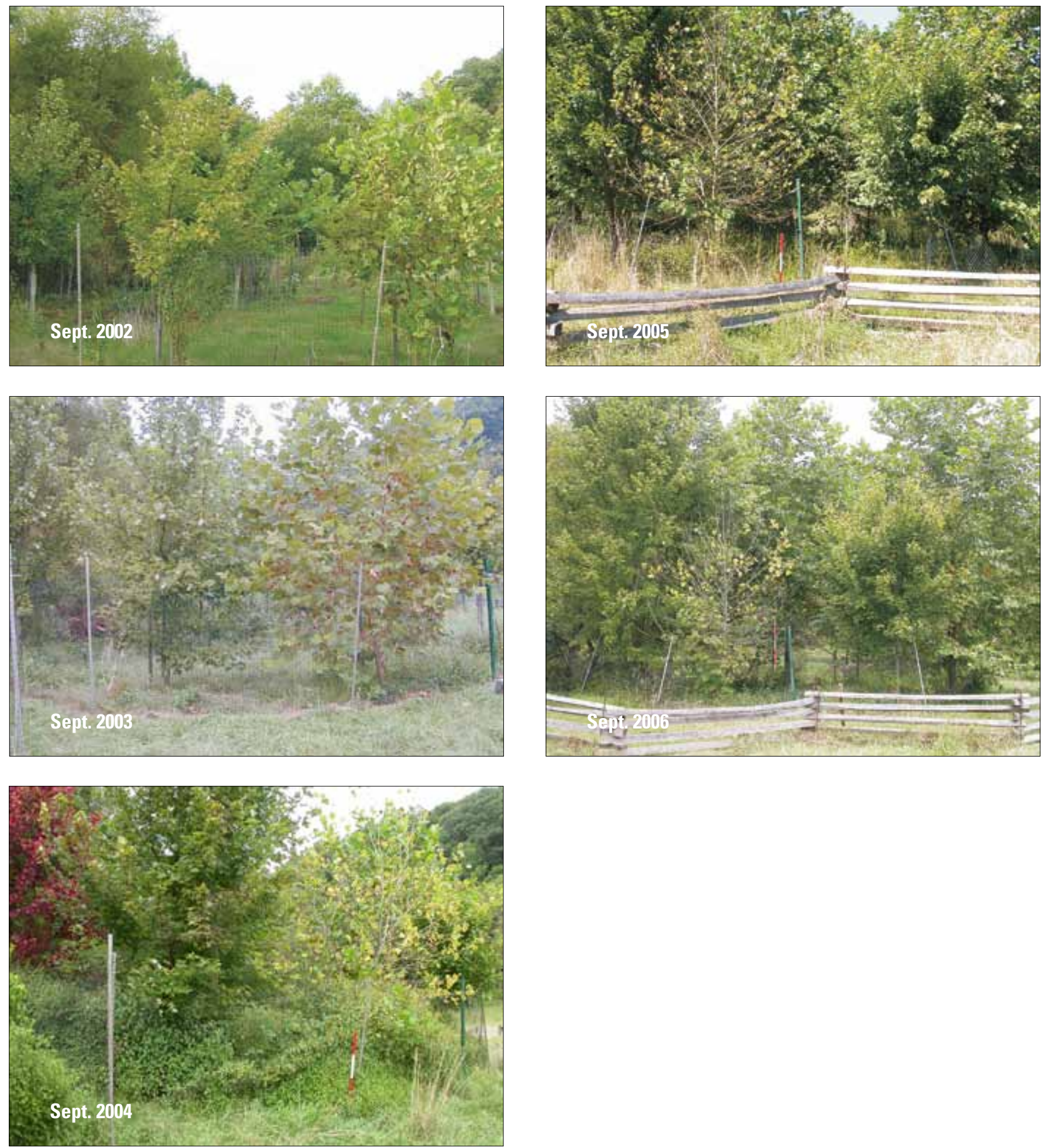

Figure 5-7. Annual views of riparian-buffer plantings in group 15, Tredyffrin Township, Chester County, Pennsylvania. (See figure 5-1 for location.) 

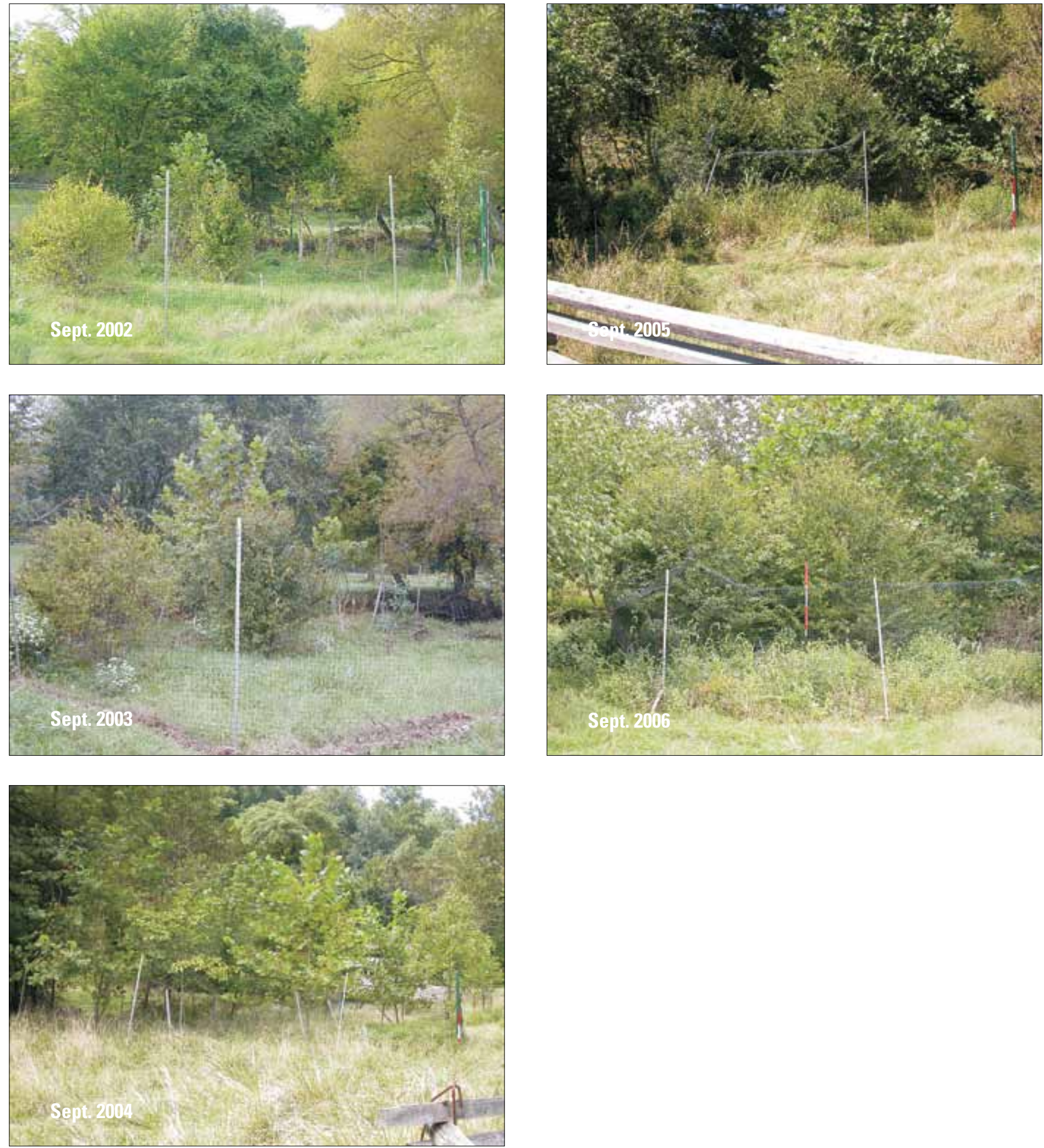

Figure 5-8. Annual views of riparian-buffer plantings in group 17, Tredyffrin Township, Chester County, Pennsylvania. (See figure 5-1 for location.) 

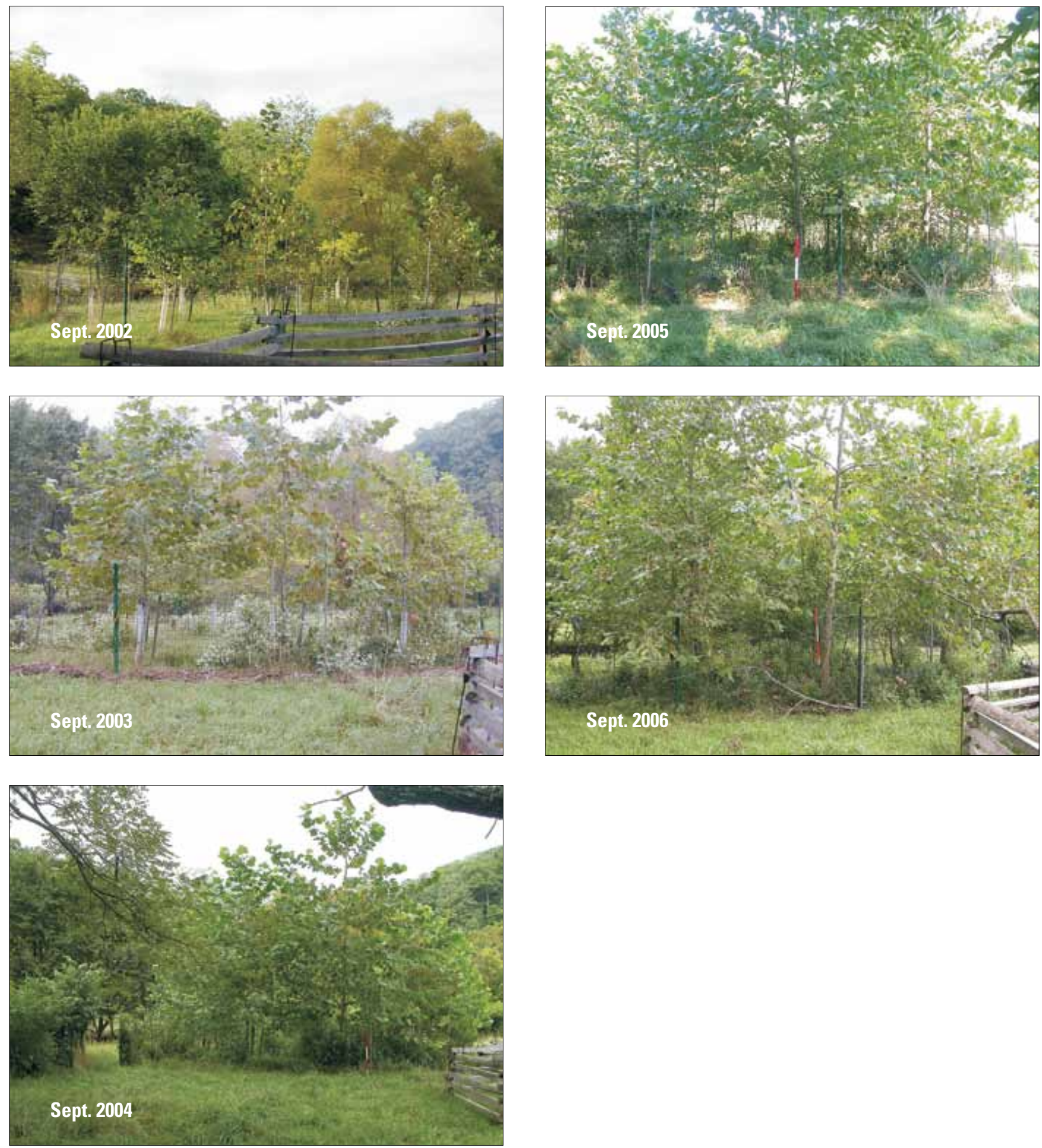

Figure 5-9. Annual views of riparian-buffer plantings in group 18, Tredyffrin Township, Chester County, Pennsylvania. (See figure 5-1 for location.) 

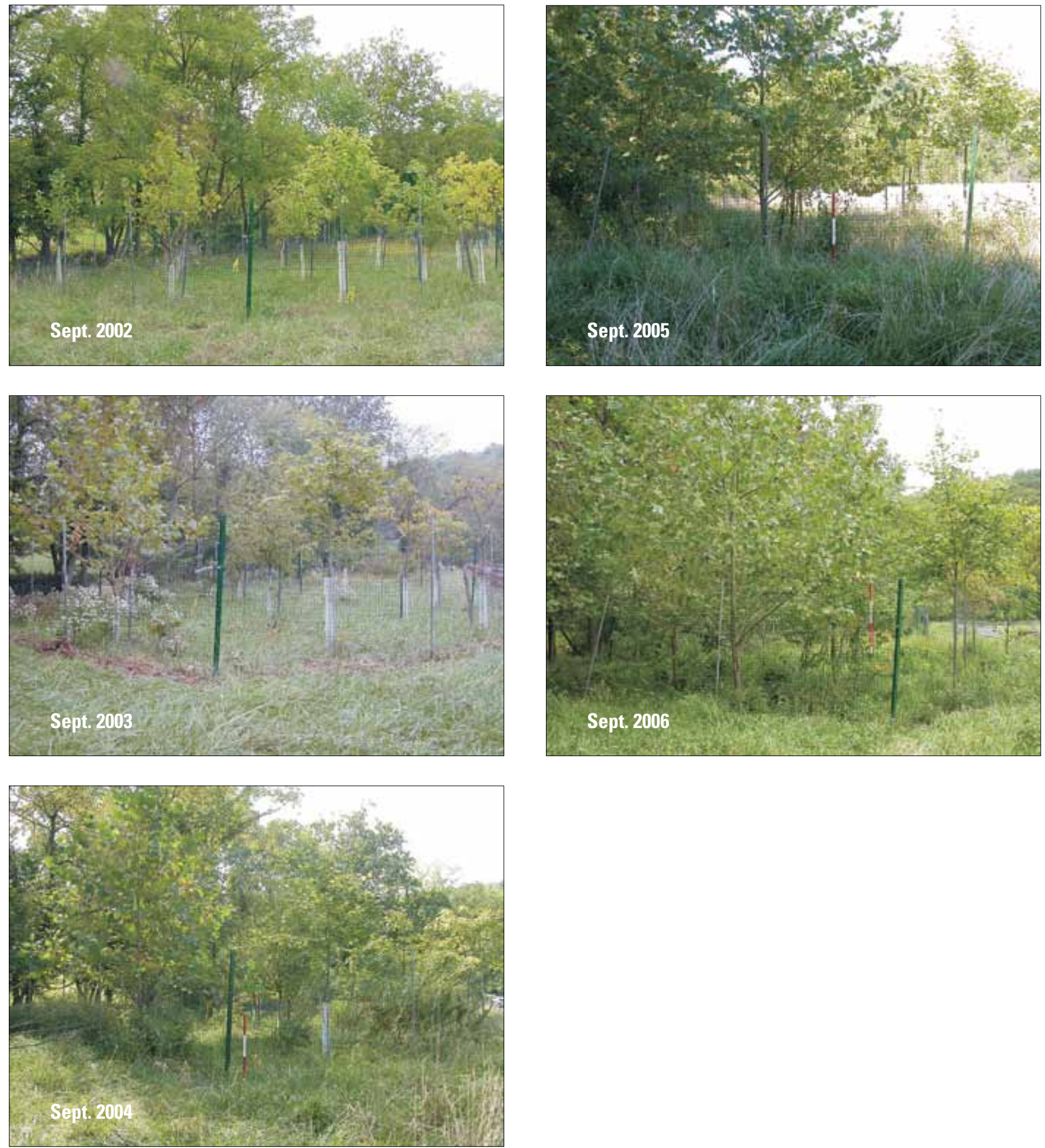

Figure 5-10. Annual views of riparian-buffer plantings in group 24, Tredyffrin Township, Chester County, Pennsylvania. (See figure 5-1 for location.) 

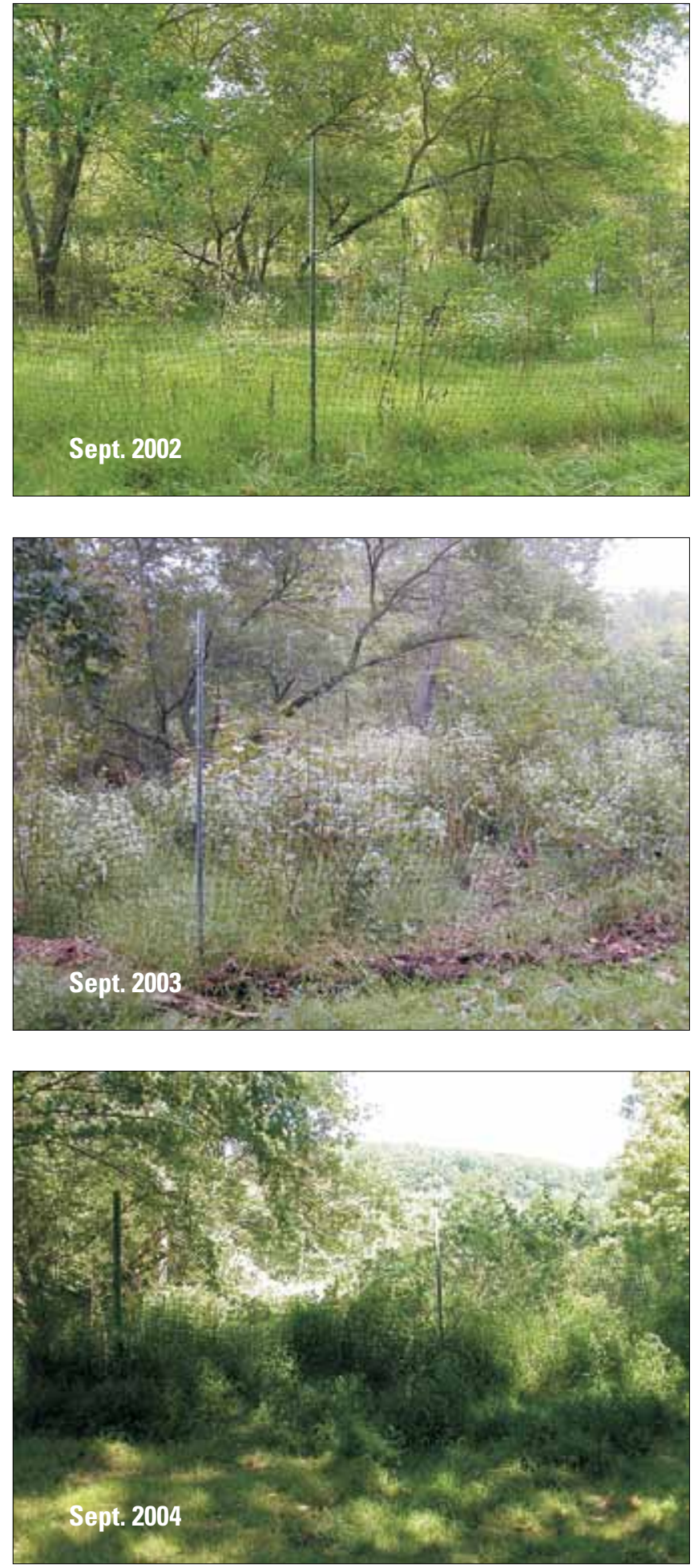
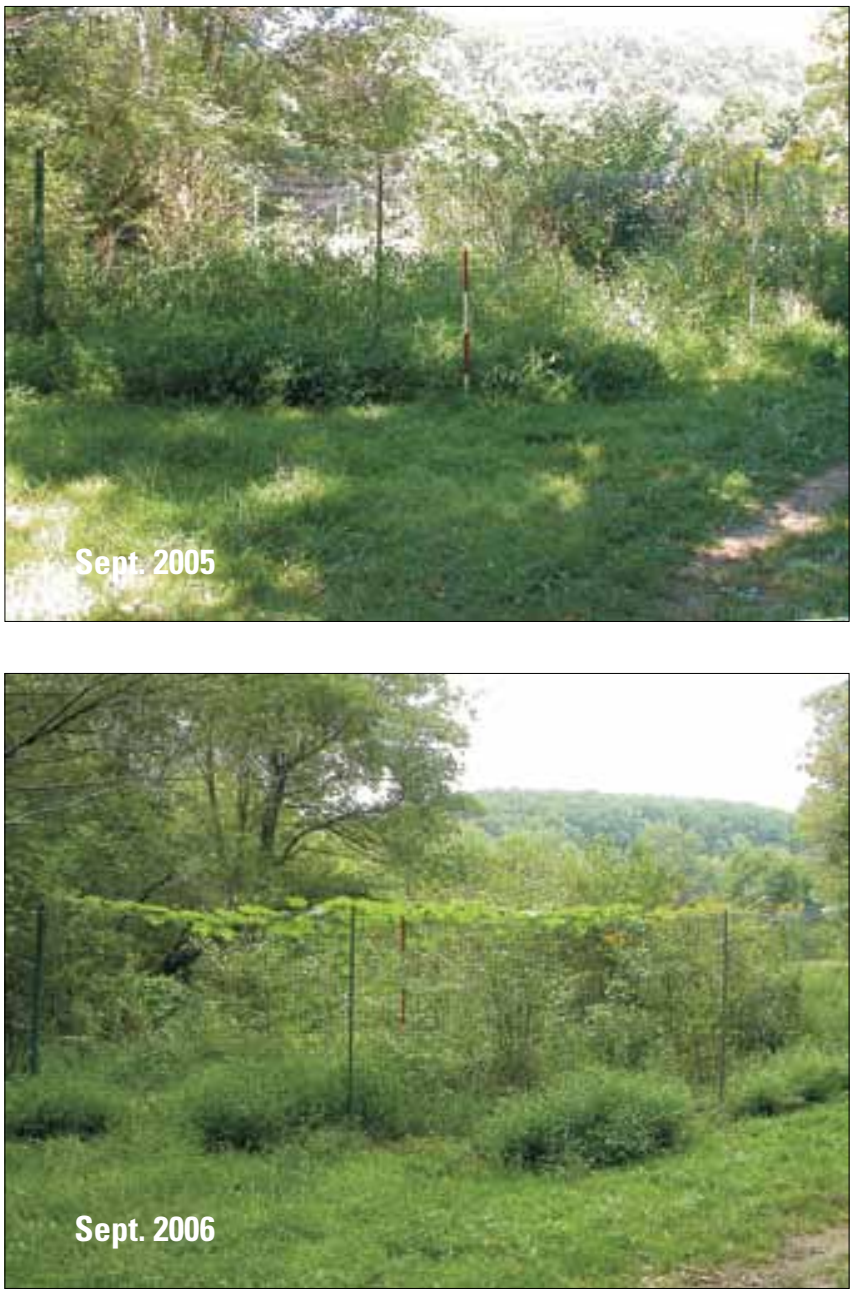

Figure 5-11. Annual views of riparian-buffer plantings in group 34, Tredyffrin Township, Chester County, Pennsylvania. (See figure 5-1 for location.) 

